
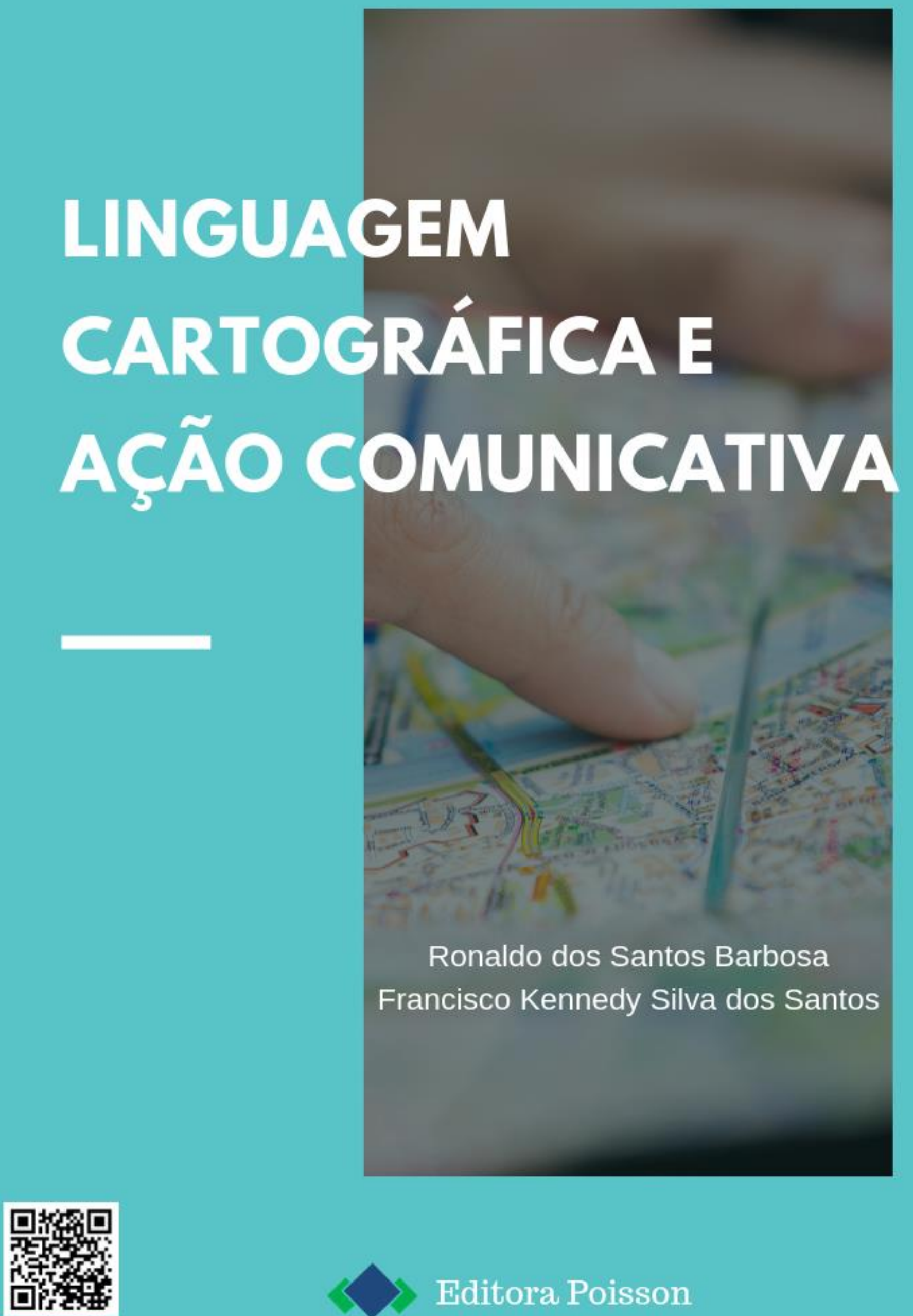
Ronaldo dos Santos Barbosa

Francisco Kennedy Silva dos Santos

\section{Linguagem Cartográfica e Ação Comunicativa}

1ạ Edição

Belo Horizonte

Poisson

2019 
Editor Chefe: Dr. Darly Fernando Andrade

\section{Conselho Editorial}

Dr. Antônio Artur de Souza - Universidade Federal de Minas Gerais Msc. Davilson Eduardo Andrade

Dra. Elizângela de Jesus Oliveira - Universidade Federal do Amazonas

Msc. Fabiane dos Santos Toledo

Dr. José Eduardo Ferreira Lopes - Universidade Federal de Uberlândia

Dr. Otaviano Francisco Neves - Pontifícia Universidade Católica de Minas Gerais

Dr. Luiz Cláudio de Lima - Universidade FUMEC

Dr. Nelson Ferreira Filho - Faculdades Kennedy

Ms. Valdiney Alves de Oliveira - Universidade Federal de Uberlândia

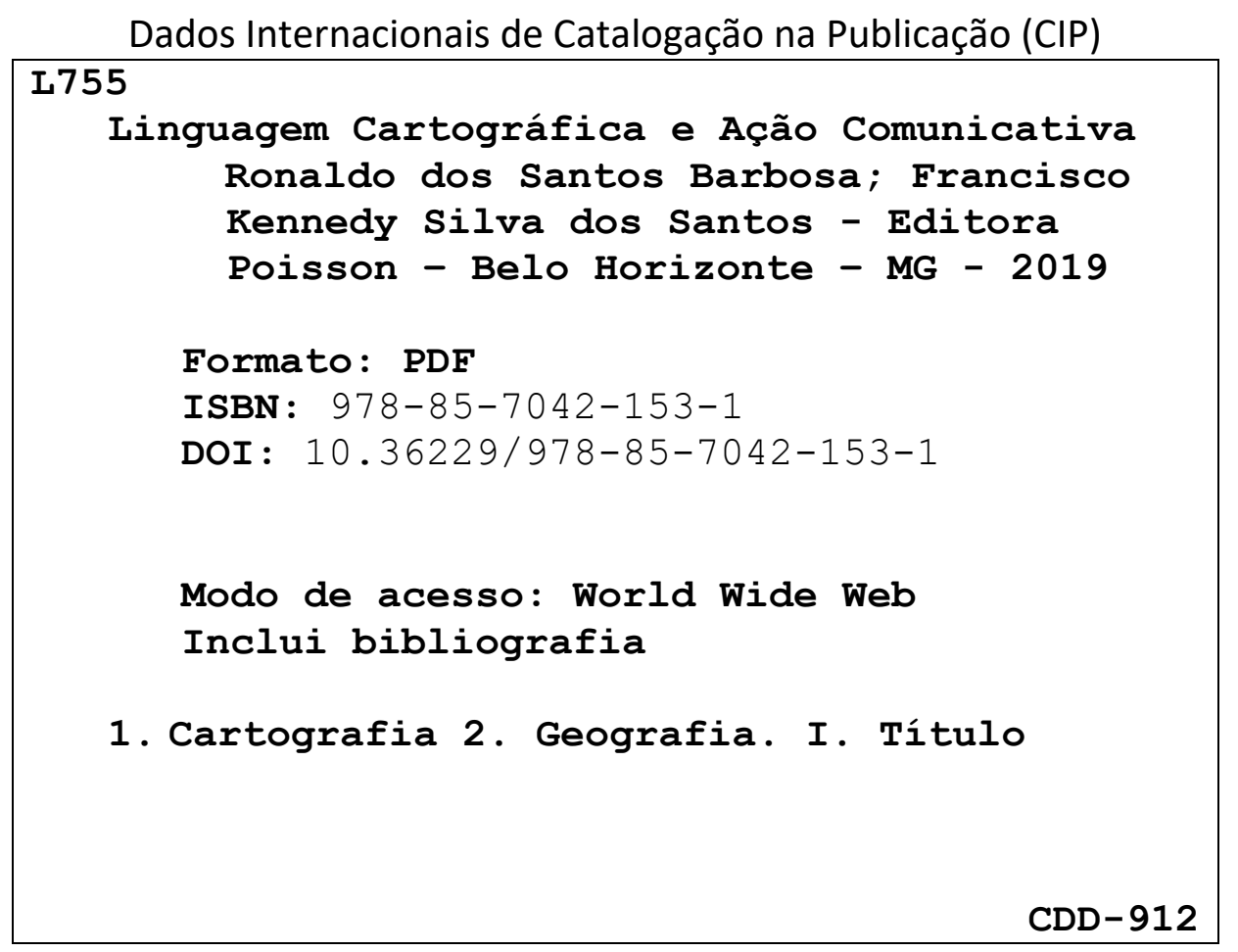

O conteúdo dos artigos e seus dados em sua forma, correção e confiabilidade são de responsabilidade exclusiva dos seus respectivos autores.

www.poisson.com.br

contato@poisson.com.br 


\section{APRESENTAÇÃO}

O debate em torno do Ensino de Geografia é crescente nos cursos de Graduação e Pós-Graduação em Geografia nas Universidades brasileiras. A preocupação com esse debate está relacionada à necessidade observada por estudiosas (os) de que, as discussões epistemológicas da Ciência Geográfica são pertinentes para as discussões da temática do Ensino de Geografia.

Por um bom período de tempo, e mesmo na atualidade, as pesquisas nos cursos de formação de professores, nas universidades privilegiaram em suas discussões, os temas como livro didático, metodologias de ensino, formação de professores, questões salariais e avaliação da aprendizagem. Essas pesquisas foram e são construídas, na perspectiva, das legislações no âmbito da educação e de realidades setoriais apresentadas, porém, muitas vezes externa às condições próprias do professor.

É neste contexto, que a obra "LINGUAGEM CARTOGRÁFICA E AÇÃO COMUNICATIVA" escrita por Ronaldo dos Santos Barbosa e Francisco Kennedy Silva dos Santos se diferencia, por apresentar significativa contribuição no ensino de geografia com o uso da linguagem cartográfica. Ao expor o estado da arte na obra, os autores oferecem tanto aos profissionais da educação, como aos profissionais da geografia, seções bem escritas e ricas em mapas conceituais, legislações do Ensino Fundamental e discussões com teóricos nos temas das Correntes Geográficas, Ensino de Geografia, Linguagem Cartográfica e a Teoria da Ação Comunicação de Jürgen Harbermas.

Convicto de que "a cartografia, enquanto área do conhecimento serviu e serve de auxílio na análise do espaço geográfico", os autores em questão escrevem a obra apoiados na hipótese, qual seja, " a partir dos pressupostos da Teoria da Ação Comunicativa de Jürgen Harbermas, entende-se que a linguagem cartográfica constitui um instrumento metodológico capaz de unir o mundo da vida (cotidiano) ao sistema (currículo), quando utilizado por professores de geografia ao trabalharem com os conteúdos escolares no chão da sala de aula.

Por meio da experiência com o tema, a partir do desenvolvimento de outras pesquisas e por meio da pesquisa - ação usada na construção da obra, os autores vivenciaram com frequência a realidade das escolas pesquisadas e discutem essa realidade com eficiência e zelo, apresentando a racionalidade das práticas pedagógicas dos docentes que observou e que interviu, com o plano de ação em acordo com o calendário escolar. Assim, a convivência favorecida por meio da pesquisa-ação deu suporte ao autor em conhecer as fragilidades do mundo da vida (teorizada por Habermas) dos professores de geografia do Ensino Fundamental de $6^{\circ}$ ao 9 o ano em Imperatriz e a forma como essas fragilidades interferem na comunicação entre professores e alunos e, também, no ensino de geografia.

$\mathrm{Na}$ obra, os autores com muito conhecimento na temática da Linguagem Cartográfica, concentram-se na compreensão da racionalidade dos professores, como caminho para o conhecimento da realidade escolar, das práticas pedagógicas e do ensino de cartografia no Ensino Fundamental de 6으 ao 9o․ A obra, portanto revela como a Teoria da Ação Comunicação contribui na emancipação humana, por meio da linguagem e como a linguagem cartográfica pode ser uma possibilidade de comunicação entre professores e alunos, na compreensão do mundo da vida e das práticas espaciais, sendo estes, objetos de estudo da geografia e abordados na pesquisa com critérios científicos.

\section{Luciléa Ferreira Lopes Gonçalves Geógrafa Doutora da UEMASUL}




\section{SUMÁRIO}

INTRODUÇÃo

.06

CAPÍTULO 1 - A PESQUISA-AÇÃo COLABORATIVA COMO ELO DE APROXIMAÇÃO ENTRE

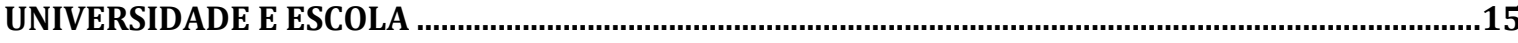

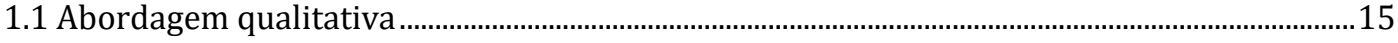

1.2 A Pesquisa-Ação como procedimento de investigação ...................................................................17

1.3 Os procedimentos de coleta de dados ..............................................................................................19

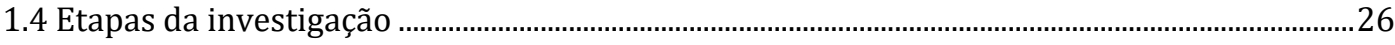

CAPÍTULO 2 - A GEOGRAFIA, A CARTOGRAFIA E O ENSINO...............................................................31

2.1 As correntes do pensamento geográfico e sua relação com a Cartografia ....................................33

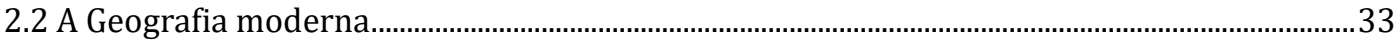

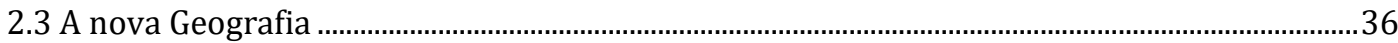

2.4 As Geografias contemporâneas .......................................................................................................

2.5 Estado da arte e perspectivas do ensino de Geografia no Brasil ...................................................42

CAPÍTULO 3 - A LINGUAGEM CARTOGRÁFICA NO CURRÍCULO DE GEOGRAFIA...............................46

3.1 Cartografia escolar no Brasil...................................................................................................................... 47

3.2 Os estudos e avanços da Cartografia Escolar no Brasil.................................................................4

3.3 Perspectivas da Cartografia Escolar no Brasil ............................................................................50

3.4 O lugar da cartografia escolar no currículo de Geografia ............................................................52

CAPÍTULO 4 - TEORIA DA AÇÃo COMUNICATIVA E A DIMENSÃO DA LINGUAGEM...........................56

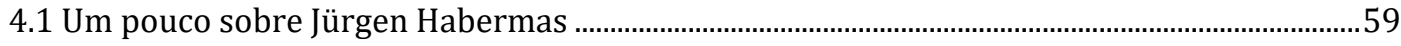

4.2 Teoria da Ação Comunicativa ....................................................................................................61

4.3 As categorias do pensamento habermasiano ……………………………………………………......64

CAPÍTULO 5 - SABERES E RACIONALIDADES DOS PROFESSORES DE GEOGRAFIA NO CHÃO DA SALA

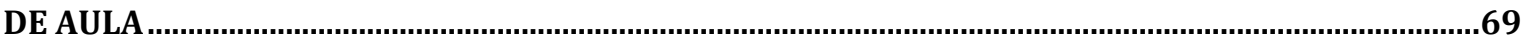

5.10 professor de Geografia e o saber da formação profissional .........................................................70

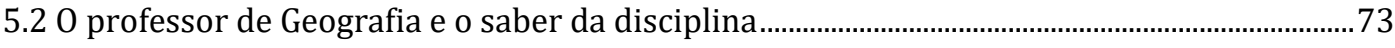

5.30 professor de Geografia e o saber curricular ……………………………………………….......75

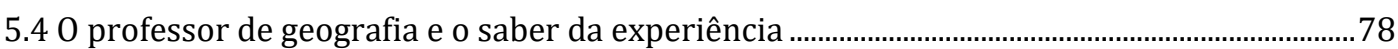

5.5 Diagnóstico das escolas, elaboração e execução do plano de ação ...................................................81

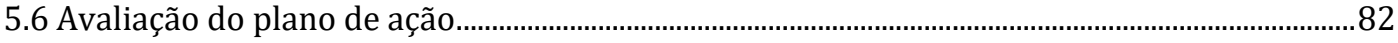

5.7 Limites e possibilidades do trabalho docente na atualidade .........................................................83

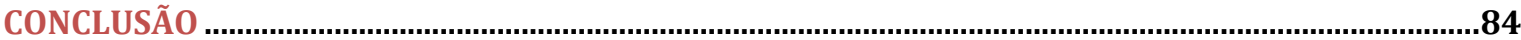

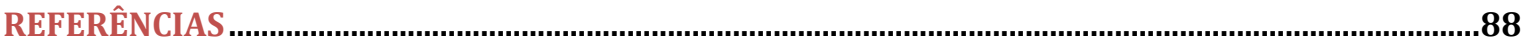

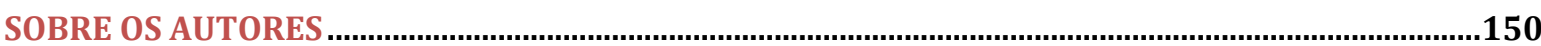




\section{Introdução}


A linguagem cartográfica tem ganhado destaque nas últimas quatro décadas, com muitas pesquisas desenvolvidas em vários níveis, desde trabalhos de iniciação científica a teses de doutorado; trabalhando com diferentes formas de uso, dos mais tradicionais - como os desenhos, os croquis e as maquetes - aos mais modernos, com emprego das geotecnologias, realidade virtual, 3D, mapas interativos etc. Esse crescimento tem sido percebido através da inserção do uso da linguagem cartográfica nos livros didáticos e currículos de alguns estados e municípios brasileiros.

A Cartografia, enquanto área do conhecimento, serviu e serve de auxílio na análise do espaço geográfico desde o início da Geografia Científica e até mesmo bem antes desta se tornar uma ciência, seja a Cartografia Técnica ou a Cartografia Arte. Entende-se por Cartografia arte os croquis ou desenhos livres, muito utilizados na descrição das paisagens e confeccionados nos trabalhos de campo, sem maiores rigores técnicos. Não se pode negar a importância que os mapas têm para os estudos ambientais, regionais, urbanos e agrários, dentre outras áreas. Na universidade, o primeiro contato que se tem com a Cartografia de teor mais técnico são nos cursos de graduação, seja bacharelado ou licenciatura, embora a carga horária e o número de componentes curriculares que englobam esta temática mudem muito de uma universidade para outra. Vale a pena frisar que nos cursos de licenciatura em Geografia, o componente curricular Cartografia tem papel fundamental na introdução da linguagem cartográfica, especialmente porque esses cursos são responsáveis pela formação dos professores de Geografia que irão atuar na educação básica.

Atualmente, existe uma grande quantidade de trabalhos referentes à origem e ao desenvolvimento da Cartografia Escolar no Brasil, que abordam diferentes níveis de ensino que vão desde as séries iniciais do ensino fundamental até o ensino superior. No entanto, é possível identificar ainda algumas lacunas no conhecimento produzido ao longo de quase quatro décadas que essa linha de pesquisa foi criada no país.

No tocante aos trabalhos desenvolvidos até o momento da escrita desta tese, vale ressaltar que alguns abordam a prática docente de professores que atuam no ensino da Geografia, com formação específica ou não, enquanto a grande maioria dos estudos dão ênfase à aprendizagem em Geografia, em especial focando o mau uso da linguagem cartográfica nas séries iniciais. Vale frisar que o professor das séries iniciais do ensino fundamental não tem formação em Geografia, visto que, em geral, quem trabalha com esse nível de ensino são os pedagogos. São poucos os trabalhos referentes ao processo de ensino ou práticas docentes de professores da disciplina no uso da linguagem cartográfica no ensino fundamental anos finais, ensino médio e ensino superior.

Ao fazer uma análise dos Parâmetros Curriculares Nacionais (PCN) de Geografia, percebe-se que a recomendação para utilização da linguagem cartográfica no ensino de Geografia aparece no terceiro ciclo (6을 $7^{\circ}$ ano). No referido documento, a Cartografia deve ser inserida como uma linguagem capaz de aproximação dos lugares e do mundo (BRASIL, 1998). No entanto, são poucos os trabalhos que abordam esse nível de ensino e as poucas abordagens existentes se dedicam a entender como o aluno usa a linguagem cartográfica para compreender os conteúdos geográficos através do raciocínio espacial. Isso resulta, na maioria das vezes, em críticas ao trabalho do professor e, como resultado da pesquisa, uma proposta metodológica de como ensinar os conceitos cartográficos ou uso da linguagem cartográfica para alunos ou escolares de forma eficiente.

Com relação aos estudos desenvolvidos no Brasil a partir do final da década de 1970, é possível apresentar um desenho das principais teorias que têm norteado os trabalhos com a linguagem cartográfica. Inicialmente e majoritariamente tem-se os trabalhos que utilizaram a Epistemologia Genética de Jean Piaget, que, de modo geral, enfocam a aprendizagem dos conceitos e noções espaciais e são voltados às séries iniciais do ensino fundamental. Existem ainda os trabalhos orientados pela Semiologia Gráfica de Jaques Bertin, em especial os trabalhos com atlas escolares, gráficos e Cartografia Temática. É possível também identificar o uso da Teoria Simbólica (Dialogismo) de Mikail Bakhtin e ainda mais recentemente os trabalhos orientados pela Teoria Histórico-Cultural, de Vygotsky, Teoria do Ensino Desenvolvimental, de Davidov, e Teoria da Complexidade, de Edgar Morin.

Conforme exposto acima, percebe-se que diferentes abordagens foram realizadas com o intuito de oferecer melhores reflexões sobre o trabalho com os conteúdos e conceitos da Cartografia Escolar. Embora essas pesquisas tenham sido desenvolvidas em programas de pós-graduação em Geografia, nota-se que os acadêmicos da graduação têm tido pouco contato com eles durante sua formação inicial; somente depois de atuantes em sala de aula na educação básica é que percebem a importância e necessidade do uso da linguagem cartográfica no processo de transformação pedagógica dos conteúdos escolares.

É valido lembrar que nem sempre estes profissionais (licenciados), ao saírem das universidades, sentemse preparados para ministrar aulas sobre os conteúdos que envolvem conceitos cartográficos, ou até 
mesmo usar a linguagem cartográfica para facilitar o processo de transformação pedagógica dos conteúdos escolares de Geografia. Outra realidade muito presente no Brasil e, no caso específico desta pesquisa, no Maranhão, diz respeito ao elevado número de professores com diferentes formações ministrando aulas de Geografia na educação básica. Em geral, esses profissionais sentem dificuldades ao trabalharem os conteúdos de Cartografia, bem como os de Geografia Física (MORAIS, 2014). Em trabalhos anteriores, foi possível constatar essa realidade na cidade de Imperatriz-MA (BRITO; RODRIGUES; BARBOSA, 2011).

Devido aos fatores expostos, o estado do Maranhão tem apresentado um péssimo desempenho nas avaliações oficiais nos últimos anos, como o Exame Nacional do Ensino Médio (Enem) e Prova Brasil, o que chegou a ser manchete em jornais de circulação nacional, bem como nas redes sociais. A Secretaria de Estado da Educação (SEDUC), através de uma equipe de profissionais, criou, em 2010, o Referencial Curricular de Geografia do ensino fundamental (RCGEF) do $6^{\circ}$ ao $9^{\circ}$ ano, alegando maior empenho para melhoria da qualidade do ensino público no estado. Desde então, a SEDUC passou gradualmente para os municípios a responsabilidade de gestão do ensino fundamental, ficando a cargo da Secretaria de Educação de cada município a implantação do novo currículo criado naquele ano.

No entanto, essa implantação não foi possível em alguns municípios, seja por questões políticas ou até mesmo por falta de investimento na formação continuada dos professores para trabalharem com o novo currículo, como foi o caso de Imperatriz. Segundo a Secretaria Municipal de Educação de Imperatriz, o município não adotou o currículo a partir de 2011 em razão do não cumprimento de um acordo firmado entre a SEDUC e a Secretaria Municipal de Educação (SEMED) para realização de programa para formação continuada com os professores que ministram aulas nos anos finais do ensino fundamental. Imperatriz passou a utilizar o currículo a partir de 2012, mas como opção, e não como currículo obrigatório, deixando as escolas livres para fazerem alterações e adequações.

Vale ressaltar que a ocupação do oeste maranhense, em especial a cidade de Imperatriz, deu-se na segunda metade do século XIX, com a fundação da vila de Santa Tereza (atual cidade de Imperatriz). Da fundação da vila, em 1852, até a década de 1950, o local permaneceu à frente de expansão, marcado pela relação entre índios e posseiros. A partir de então, começaram as obras de construção da rodovia BR-010 (Belém-Brasília), o que mudou a dinâmica de ocupação da área, instalando-se a frente pioneira. Assim, os atores passarm de índios e posseiros para fazendeiros e latifundiários.

Juntamente com a frente pioneira começou, a partir da década de 1960, o processo de grilagem das terras dos vales dos rios Tocantins e Pindaré (ASSELIN, 1989). Nesse contexto, a ocupação da microrregião de Imperatriz teve seu processo acelerado a partir da abertura da rodovia BR-010, concluída no final da década de 1950. Na década seguinte, o processo de ocupação foi intensificado com a chegada de um grande número de migrantes vindos em grande maioria do leste do estado, bem como de outros estados da Região Nordeste.

Posteriormente, com a implantação do Projeto Grande Carajás, na década de 1980, a ocupação seguiu o eixo da rodovia citada anteriormente. A ação, além de atrair mão de obra para as cidades de Imperatriz e Açailândia, desabrigou muitas famílias que viviam nas áreas incorporadas ao projeto. Sem condições de permanecer no campo, essas famílias eram obrigadas a migrar para as cidades vizinhas, sendo Imperatriz a melhor opção no período.

A partir da década de 1960, Imperatriz perdeu território, pois alguns povoados reivindicaram a emancipação do município. Na Figura a seguir, Santos (2017) representa cartograficamente esse processo de fragmentação do território de Imperatriz dando origem a outros municípios. Vale ressaltar que, embora tenham sido criados novos municípios, os mesmos continuaram dependendo de Imperatriz especialmente os serviços de saúde, educação e comércio (SOUSA, 2015). 
Figura 1 - Localização da área de estudo.

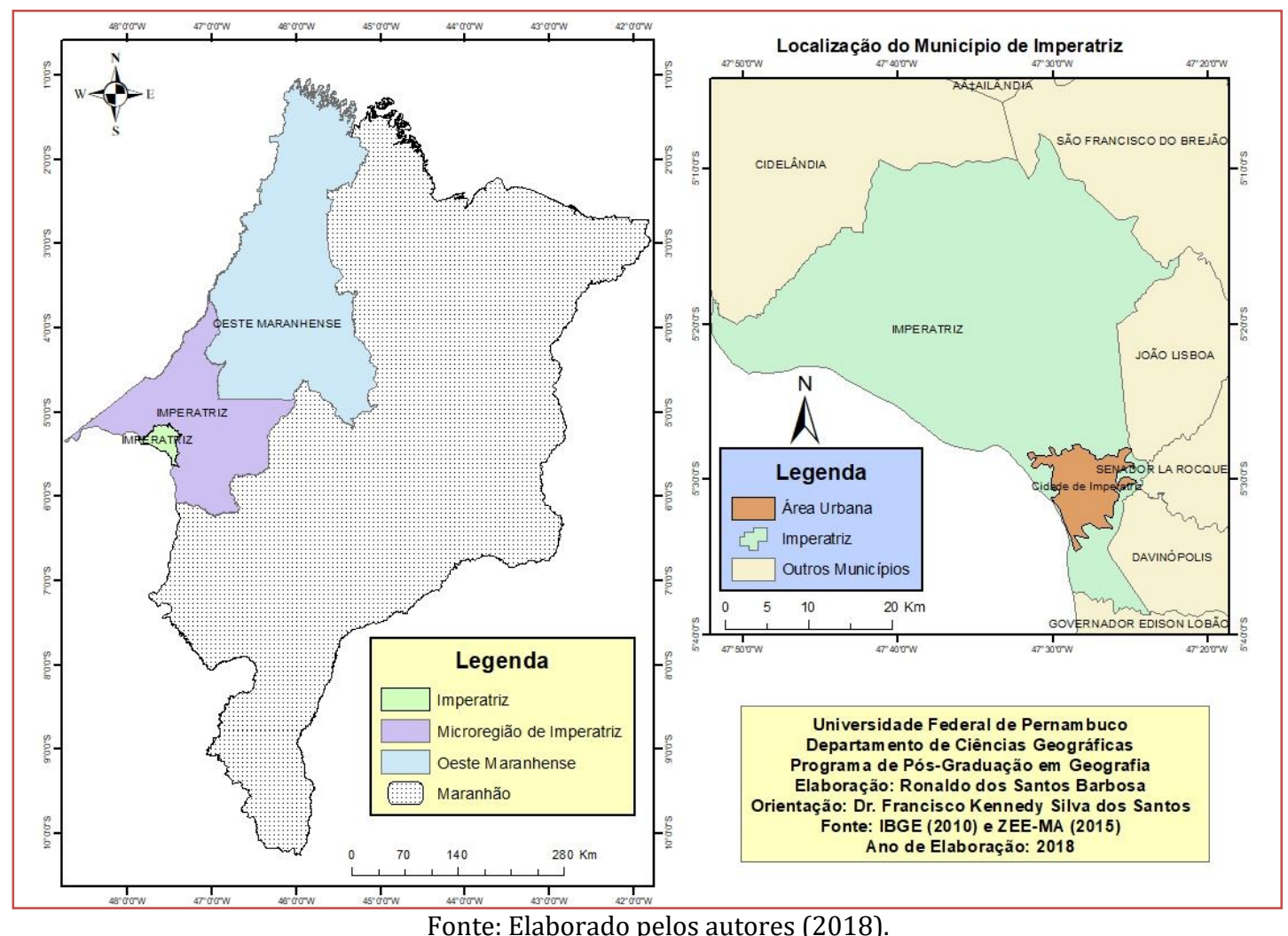

Figura 2 - Evolução da divisão do município de Imperatriz.

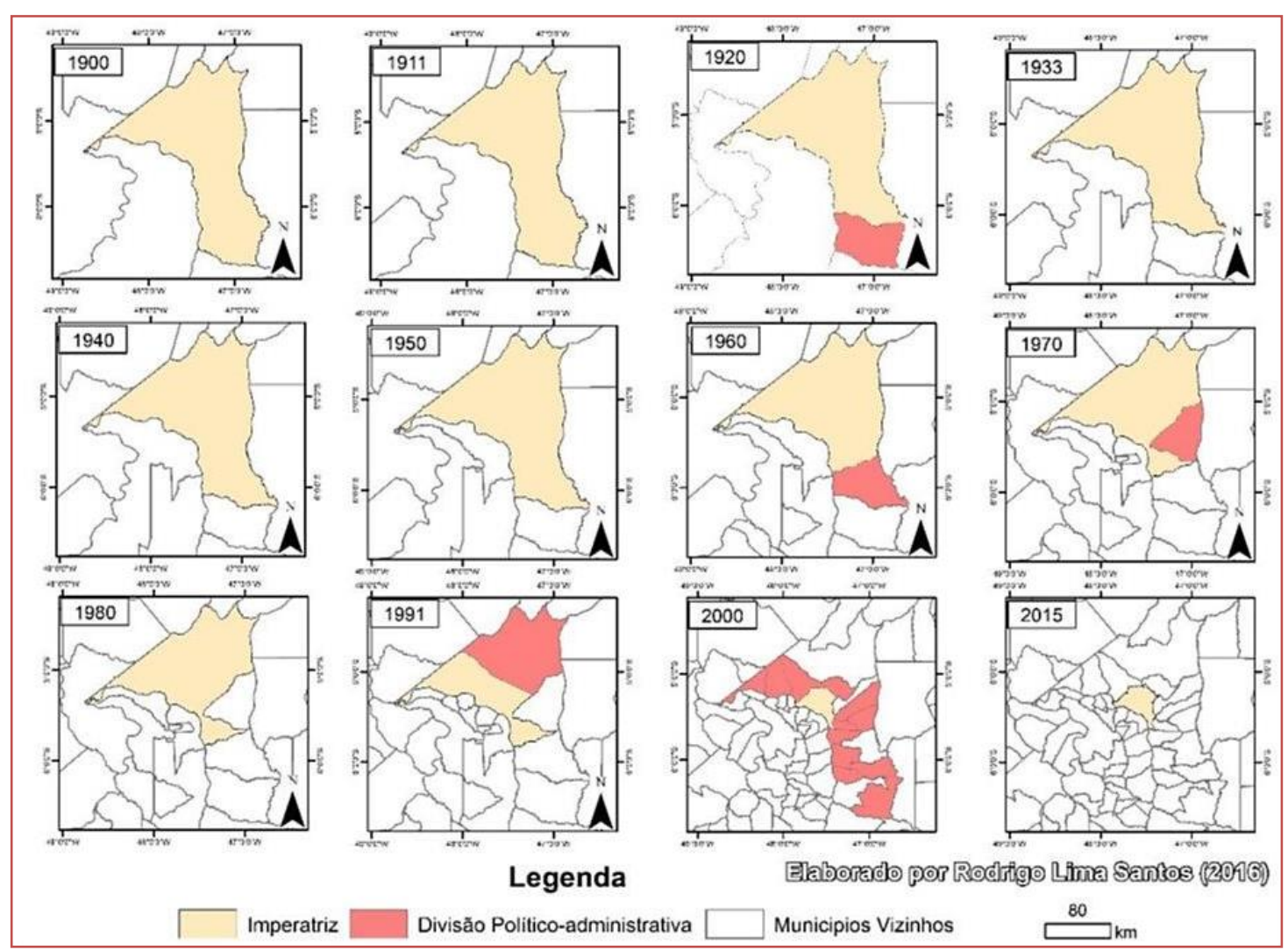

Fonte: Santos (2017). 
Com isso, mudou completamente a realidade do ensino de Geografia no estado e, em Imperatriz, não poderia ser diferente, visto que a cidade passou a receber uma grande quantidade de alunos oriundos da rede estadual. No ano de 2010, o município contava com cerca de 10.900 alunos matriculados nos anos finais do ensino fundamental; em 2012 esse número subiu para aproximadamente 14.000 (IMPERATRIZ, 2014). Essa nova realidade levou o município a criar estratégias para atender à nova demanda, dentre as quais se pode citar: aluguel de prédios para o funcionamento de escolas, convênio com pequenas escolas particulares, contratação de novos professores e criação de condições para o trabalho docente. Na zona urbana (Figura 2), em 2014, o município contava com 26 escolas que funcionavam em prédios próprios e 62 em prédios alugados, segundo dados do Plano Municipal de Educação daquele ano.

Além das mudanças ocorridas no cenário educacional, é importante citar algumas mudanças ocorridas na cidade e no entorno, como a mudança de governo do PMDB, grupo aliado ao governo estadual, para o PSDB, grupo de oposição. Isso ocasionou sucessivas greves de professores por melhorias das condições de trabalho e salários, além de manter algumas conquistas, como o vale alimentação e jornada de trabalho semanal de 16h/aulas. Outro fator considerado relevante foi a implantação do grupo Suzano Papel e Celulose, que acarretou na vinda de milhares de trabalhadores de diferentes regiões do país em busca de emprego nas obras de implantação do parque industrial, provocando também o aumento da violência, da prostituição e a especulação imobiliária. Vale citar também mudanças no ensino superior, com a criação de novos cursos na Universidade Estadual do Maranhão (Licenciatura em Física e Engenharia Florestal) e na Universidade Federal (Licenciatura Interdisciplinar em Ciências Humanas e Naturais, Medicina, Enfermagem, Nutrição e Jornalismo), no Instituto Federal de Educação Tecnológica (Licenciatura em Física, Engenharia Civil e Engenharia Elétrica).

As mudanças ocorridas na cidade de Imperatriz refletem, de certa forma, no cenário da educação. 0 presente estudo visa compreender a realidade do ensino de Geografia do 6ㅇ ao 9o ano do ensino fundamental no município diante dos acontecimentos que envolvem a política, a economia e a sociedade nos dez anos que antecedem este trabalho. Nesse sentido, é salutar fazer análise das práticas docentes no tocante ao uso da linguagem cartográfica em sala de aula no tratamento pedagógico dos conteúdos da Geografia. A oferta de serviços especializados na área da saúde e educação atraiu população de outros estados e municípios fazendo com que houvesse a necessidade da criação de novos bairros, como mostra o mapa da figura 3.

Considera-se importante evidenciar a aproximação do autor com a temática. A vivência durante a graduação e mestrado com as temáticas físico-ambientais proporcionou um contato com a Cartografia Teórica (sistemática), Cartografia Temática e geoprocessamento. Posterior a isso, a admissão como docente no curso de Licenciatura em Geografia na Universidade Estadual do Maranhão (UEMA), campus de Imperatriz - hoje transformada em Universidade Estadual da Região Tocantina do Maranhão (UEMASUL) - permitiu o contato com outra realidade: a dos professores que ministram aulas de Geografia na educação básica. 0 desenvolvimento de projetos de pesquisa e extensão permitiu uma aproximação e a melhor compreensão da realidade que os professores da educação básica vivenciam no cotidiano da sala de aula.

As visitas frequentes às escolas da rede pública municipal na área urbana de Imperatriz, acompanhando alunos das disciplinas de Prática de Vivência Curricular e Estágio Curricular Supervisionado no Ensino Fundamental, fizeram ver e pensar sobre a relação entre o ensino de Geografia na educação básica e os conteúdos de Cartografia presentes nesse nível de ensino, seja como conteúdo ou linguagem. Isso impulsionou a busca por compreensão e intervenção junto às escolas. Para isso, buscou-se algumas respostas na literatura, na investigação científica e na extensão.

Alguns projetos foram desenvolvidos a partir de 2008 até o momento da redação deste trabalho. Inicialmente, foram realizados projetos de pesquisa e posteriormente de extensão. Foram desenvolvidos projetos com auxílio financeiro da Fundação de Amparo à Pesquisa e ao Desenvolvimento Científico e Tecnológico do Maranhão (FAPEMA), sendo o último projeto ligado a temática da tese e outros com auxílio da UEMA. Atualmente, o desafio gira em torno de compreender qual o lugar da linguagem cartográfica nas práticas docentes dos professores de Geografia do 6으 ao 9o ano do ensino fundamental (Anexo II) e que racionalidade orienta as práticas dos professores no tocante ao uso da linguagem cartográfica em sala de aula. 0 projeto contou com a participação de um bolsista de extensão (Anexo III) e foi desenvolvido em parceria com o Laboratório de Cartografia e Ensino (LabCartE) da UEMASUL. 
Figura 3 - Evolução da criação de bairros na cidade de Imperatriz.

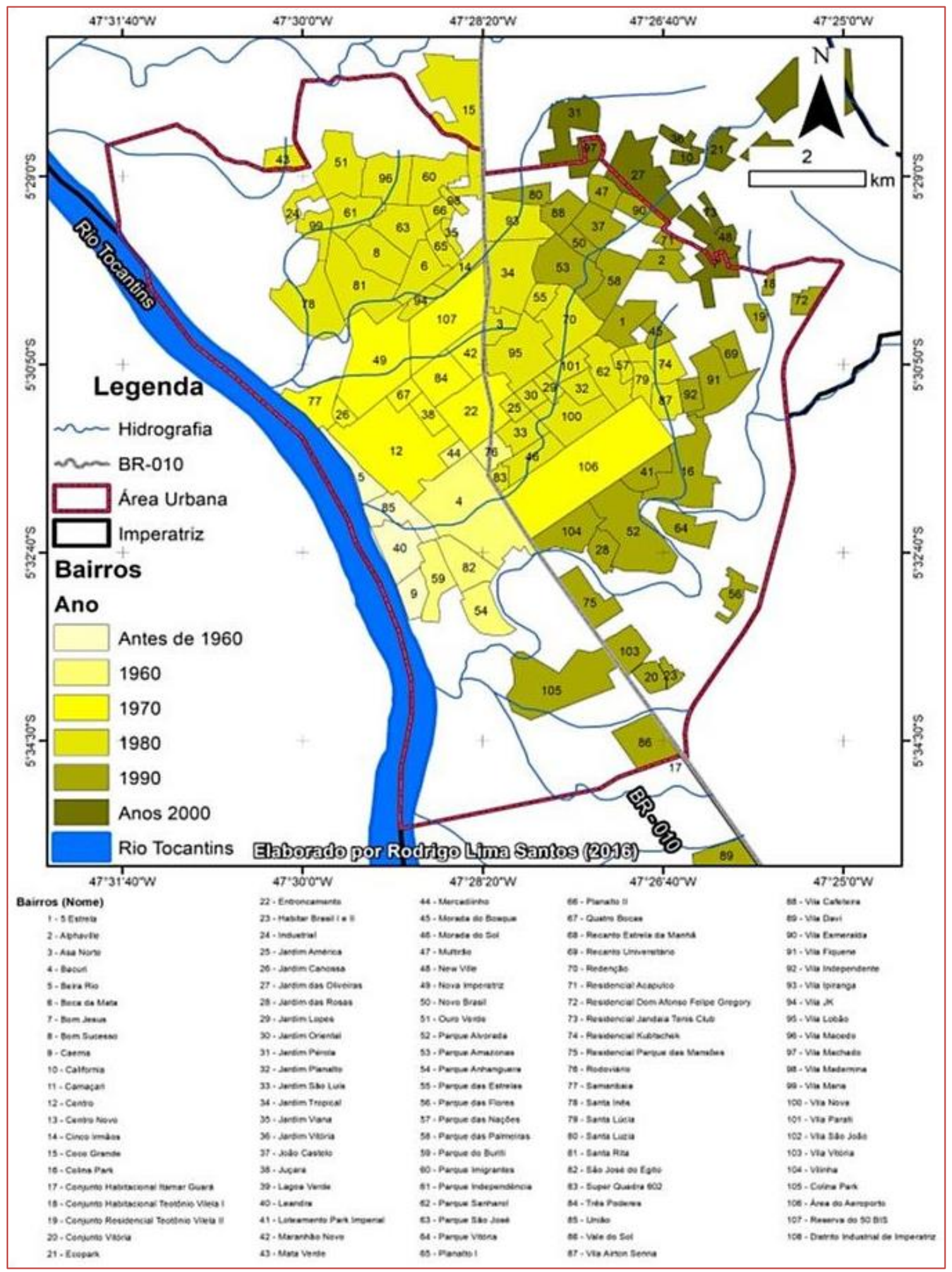

Fonte: Santos (2017)

O ingresso no Programa de Pós-Graduação em Geografia em nível de doutorado me colocou diante de inúmeros desafios. Dentre eles, vale citar alguns que considero relevantes e que tenho tentado superar ao longo da trajetória. Primeiro, a mudança de postura epistemológica, pois, mesmo trabalhando com ensino de Geografia na universidade, o pensamento quantitativo-sistêmico neopositivista ainda está presente na forma de interpretar e representar o conhecimento. Incorporar uma nova forma de pensar a pesquisa, o 
ensino, os sujeitos e a realidade a partir da Teoria Crítica, em especial utilizando os pressupostos da Teoria da Ação Comunicativa de Habermas, não tem sido fácil.

Momentos de empolgação aliados a momentos de angústia têm feito parte da trajetória durante o doutorado, desde as disciplinas com as primeiras leituras sobre a TAC de Habermas até os acontecimentos mais recentes sobre a situação política e educacional no Brasil, no Maranhão e em Imperatriz. No entanto, problemas dessa natureza fazem crescer e aprender a enfrentar os desafios postos no dia a dia. Por fim, aproveita-se para parafrasear o pensamento da pesquisadora dra. Elza Passini (2007, p. 16), pela qual tenho profunda admiração por sua trajetória no ensino de Geografia e na Cartografia Escolar: "0 que nos torna um profissional não é apenas o diploma, mas a capacidade de conectar teoria, discurso e ação de posse de uma racionalidade capaz de nos orientar a encontrar soluções possíveis para o bem coletivo".

A partir do exposto acima, tem-se como questão principal da pesquisa: Como os professores de Geografia do 6으 ao 9o ano do ensino fundamental da rede pública municipal da cidade de Imperatriz-MA utilizam a linguagem cartográfica ao trabalharem os conteúdos geográficos em sala de aula?

Com isso, surgem outras questões importantes para entendimento do problema da pesquisa: até onde as produções científicas na linha da Cartografia Escolar têm contribuído para melhorias no ensino de Geografia do 6으 ao 9a ano do ensino fundamental? Qual o lugar da linguagem cartográfica no currículo de Geografia do 6으 ao 9o ano do ensino fundamental? Quem são os professores que ministram aulas de Geografia do 6ำ ao 9o ano do ensino fundamental? Que racionalidade(s) move(m) as práticas dos professores em situação de aula?

Considera-se que houve um crescimento do uso da linguagem cartográfica por professores de Geografia. Esse crescimento ocorreu nas duas últimas décadas, tendo como base os estudos desenvolvidos no Brasil a partir do final da década de 1970, sob a orientação de diversas teorias, dentre as quais pode-se destacar: Epistemologia Genética, de Jean Piaget; Semiologia gráfica, de Jaques Bertin; Dialogismo, de Bakhtin; Teoria Histórico-Cultural, de Vygotsky; e, dentro da mesma linha teórica, a Teoria Desenvolvimental, de Davidov; além de Teoria da Complexidade, de Edgar Morin. Todo esse arsenal teórico-metodológico tem se mostrado eficiente no auxílio do trabalho docente em diferentes níveis de ensino.

Vale ressaltar que este trabalho tem sido desenvolvido de forma conjunta, aliada a uma boa base teórica e pedagógica, não desconsiderando a importância e contribuição de tais teorias que nortearam os estudos da Cartografia Escolar, mas com o intuito de trazer contribuições para o processo de ensino de Geografia nos anos finais do ensino fundamental, é a partir dos pressupostos da Teoria da Ação Comunicativa, de Jürgen Habermas, que entende-se que a linguagem cartográfica constitui um instrumento metodológico capaz de unir o mundo da vida ao sistema quando utilizado por professores de Geografia ao trabalharem com os conteúdos escolares no chão da sala de aula.

A obra tem como objetivo geral compreender, a partir dos pressupostos da Teoria da Ação Comunicativa, que racionalidade os professores de Geografia dos anos finais do ensino fundamental na rede pública municipal da cidade de Imperatriz-MA utilizam ao elegerem a linguagem cartográfica como instrumento metodológico no processo de transformação pedagógica dos conteúdos escolares em sala de aula.

Como objetivos específicos pode-se elencar: Fazer uma análise do processo de construção teórica da Geografia e da Cartografia a partir das matrizes epistemológicas que conduziram a construção do conhecimento científico e seus reflexos no ensino de Geografia; Identificar as teorias que têm norteado os trabalhos da Cartografia Escolar e apontar as possíveis contribuições para o ensino no ensino da Geografia do 6ํㅜ ao 9o ano do ensino fundamental; Apontar como a linguagem cartográfica aparece no currículo de Geografia do 6으 ao 9 ano (PCN, Referencial curricular do estado do Maranhão e BNCC) do ensino fundamental; Caracterizar os pressupostos da Teoria da Ação Comunicativa de Jürgen Habermas, tendo em vista a sua aplicação no ensino de Geografia com ênfase no uso da linguagem cartográfica; Caracterizar quem são os professores que ministram aulas de Geografia e como utilizam a linguagem cartográfica ao trabalharem com os conteúdos escolares em sala de aula e por fim analisar, a partir do contato com os pressupostos da Teoria da Ação Comunicativa, as práticas dos professores, a fim de compreender a racionalidade que orienta suas práticas.

A linguagem cartográfica está associada ao desenvolvimento de estruturas do pensamento que possibilitam a leitura, compreensão e produção de representações espaciais (mapas mentais) que possuem uma simbologia específica cuja mensagem pode ser lida e interpretada. Para Castellar (2012, p. 129), a Cartografia é considerada "[...] uma linguagem, um sistema de comunicação imprescindível em todas as esferas da aprendizagem em Geografia, articulado fatos, conceitos e sistemas conceituais que permitem ler e escrever as características do território". 
Por meio do uso da linguagem cartográfica, é possível desenvolver nos alunos uma forma de pensar geográfica; para Cavalcanti (2002), essa forma de pensar a Geografia por parte do aluno passa, necessariamente, pelos conceitos geográficos. Para a autora, a relação entre a Geografia Acadêmica e a Geografia Escolar é bastante complexa, visto que as duas formam uma unidade, mas não são idênticas. A Geografia Acadêmica é formada de teorias, conceitos e métodos referentes à problemática de seu objeto de estudo, enquanto a Geografia Escolar corresponde ao conjunto de saberes dessa outra Geografia, bem como de outras áreas do conhecimento, que têm lugar na educação básica; tudo isso convertido em conteúdos escolares.

A Geografia, tanto no espaço acadêmico quanto na educação básica, tem por função contribuir para a construção de conhecimentos significativos para a vida dos educandos. Para isso, as competências e habilidades a serem desenvolvidas nos educandos, por meio dos conteúdos geográficos, devem proporcionar uma reflexão crítica acerca da sociedade na qual eles vivem e, principalmente, sobre o espaço que ocupam, visando à compreensão de como este é (re)organizado cotidianamente. (BARBOSA, 2010, p. 1)

Sendo assim, para contribuir de forma efetiva no processo de desenvolvimento do raciocínio geográfico, nada melhor do que a utilização de uma metodologia que faça uso da representação espacial como expressão e linguagem, a fim de ampliar e contribuir na formação de uma leitura geográfica mais próxima da realidade espacial do educando. Independente do conteúdo geográfico a ser trabalhado, é possível a utilização da linguagem cartográfica aliada à argumentação e uma boa base pedagógica, necessária à transformação pedagógica dos conteúdos em sala de aula.

Diante do exposto é que se justifica a necessidade da realização de uma investigação mais acurada sobre o processo de ensino em Geografia na rede pública municipal na cidade de Imperatriz-MA. Com a realização do presente estudo, espera-se contribuir para a melhoria no processo de ensino de Geografia nos anos finais do ensino fundamental, utilizando a linguagem cartográfica como um instrumento de transformação pedagógica dos conteúdos escolares em sala de aula e não apenas a escrita e a fala, como de costume. 


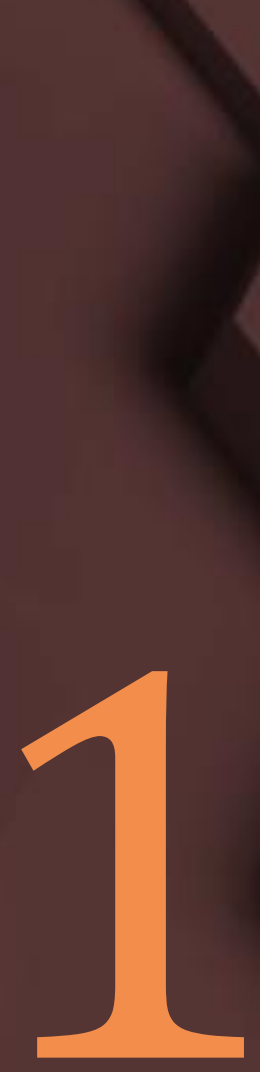

A pesquisa-ação colaborativa como elo de aproximação entre universidade e escola 
Neste capítulo serão tratadas as questões metodológicas que norteiam a pesquisa. Inicialmente, faz-se uma explicitação da teoria em que se fundamenta o estudo, a saber, a TAC de Habermas, para em seguida expor a forma de abordagem que se sustenta na pesquisa qualitativa. Num segundo momento, fala-se do procedimento de investigação norteado pela pesquisa-ação e, em seguida, caracterizam-se os instrumentos de coleta de dados.

0 presente trabalho pretende compreender e revelar a racionalidade pedagógica que orienta as práticas dos professores de Geografia do 6o ao 9o ano do ensino fundamental no chão da sala de aula ao utilizarem a linguagem cartográfica como instrumento de transformação pedagógica dos conteúdos geográficos, tendo como ponto central uma reflexão situada na TAC de Jürgen Habermas, que é defendida como elemento fundante para a compreensão do trabalho docente na contemporaneidade.

Partindo do entendimento de que a linguagem cartográfica constitui um princípio metodológico eficiente no processo de transformação pedagógica dos conteúdos geográficos em sala de aula, considera-se que a Cartografia, enquanto linguagem, é capaz de estabelecer relações interpessoais no âmbito de uma sala de aula, portanto, da gestão da sala de aula e, consequentemente, da gestão dos conteúdos de ensino, neste caso, os da ciência geográfica. Assim, na perspectiva da TAC, será trabalhado o conceito de racionalidade, e será observado como os princípios de uma coordenação comunicativa das ações se aplicam às interações professor-aluno, enfatizando fundamentalmente as que são requeridas para tal.

Nesse sentido, a racionalidade pedagógica, quando realizada de forma sistemática, em contextos escolares, consoante Boufleuer (2001), pode ser concebida, basicamente, de duas maneiras distintas na perspectiva dos agentes educativos: ou ela é entendida como uma ação sobre os outros, ao modo de uma ação estratégica de influenciação e de manipulação, ou é entendida como uma ação com os outros, ao modo de uma ação comunicativa, baseada na colaboração e cooperação entre as partes envolvidas.

\subsection{ABORDAGEM QUALITATIVA}

O trabalho será norteado pela abordagem qualitativa. Do ponto de vista da investigação qualitativa, procura-se a compreensão das complexas inter-relações que acontecem na vida real. Na abordagem qualitativa, é importante que o investigador esteja no trabalho de campo, aplique questionários, realize entrevistas, faça observação, emita juízos de valor e analise todo o material coletado em campo (CHIZZOTTI, 2003).

Para Chizzotti (2003), a pesquisa qualitativa engloba um campo transdisciplinar, que abriga tanto as ciências humanas quanta as ciências sociais, assumindo com isso uma postura multiparadigmática, derivada do Positivismo, da fenomenologia, hermenêutica, marxismo, teoria crítica e construtivismo, e adotando uma diversidade de métodos de investigação para o estudo de fenômenos, procurando dar a eles um sentido, bem como interpretar os significados que as pessoas atribuem a esses fenômenos.

$\mathrm{Na}$ investigação qualitativa, é essencial que a capacidade interpretativa do pesquisador nunca perca o contato com o desenvolvimento do acontecimento. Para Stake (1983), a realidade não pode ser descoberta, mas sim interpretada e construída. Ou seja, em qualquer investigação, não existe descoberta de conhecimento, mas sim construção de conhecimento. Dessa forma, a investigação qualitativa procura a lógica da construção do conhecimento.

Nesse sentido, Silveira e Córdova (2009) ressaltam que a pesquisa não se preocupa com representatividade numérica, mas sim com o aprofundamento da compreensão de um grupo social, de uma organização, enfim, com a compreensão do objeto de investigação. Os autores afirmam ainda que os pesquisadores que adotam a abordagem qualitativa, em geral opõem-se ao pressuposto que defende o uso de um método único de pesquisa. Com isso, esses estudiosos recusam o modelo positivista aplicado ao estudo de problemas sociais, pois, com base nesse modelo, os investigadores não podem fazer julgamentos, nem permitir que seus preconceitos e crenças contaminem a pesquisa.

A pesquisa qualitativa é considerada recente em comparação a outros métodos de pesquisa em ciências sociais e humanas. Teve seu início, segundo Bogdan e Biklen (1994) e Chizzotti (2003), no final do século XIX, destacando, sobretudo, os estudos sobre as populações urbanas na Europa e suas condições de vida. Em educação, as primeiras pesquisas desse tipo fazem referência à investigação qualitativa com uma variedade de termos tais como: investigação naturalista, evolução iluminativa e qualitativa, etnografia e teoria crítica, investigação-ação participativa e colaborativa (MARCONI; LAKATOS, 2004).

Para Ludke e André (2014), uma das características principais dos estudos qualitativos é o fato de os mesmos serem desenvolvidos em ambiente natural, serem ricos em dados descritivos, apresentarem um 
plano aberto e flexível, além de focalizarem a realidade de forma complexa e contextualizada. Já Minayo (2011) destaca uma das características dos estudos qualitativos, que é o trabalho com um universo de significados, motivos, aspirações, crenças, valores e atitudes, o que corresponde a um espaço mais profundo das relações, dos processos e dos fenômenos que não podem ser reduzidos à operacionalização de variáveis.

Não faz parte das pretensões deste trabalho trazer à tona a discussão sobre a diferença entre as abordagens quantitativa e qualitativa, muito menos evidenciar a melhor ou pior para a investigação que aqui se apresenta. Considera-se importante apresentar, com base na literatura existente, algumas recomendações, vantagens e dificuldades encontradas por pesquisadores qualitativos.

Para tanto, recorre-se a Alves-Mazzotti e Gewandsznajder (2000), pois os autores admitem que a adoção antecipada de um quadro teórico turva a visão do pesquisador, levando-o a desconsiderar aspectos importantes, que não se encaixam na teoria, e a fazer interpretações distorcidas dos fenômenos estudados. Nesse sentido, Marconi e Lakatos (2004) consideram que a pesquisa qualitativa deve apresentar um mínimo de estruturação, de embasamento teórico geral e um planejamento cuidadoso, para que o pesquisador não se perca no contexto da pesquisa.

No tocante às vantagens e desvantagens da pesquisa qualitativa, André (1983) destaca que a pesquisa qualitativa tem como vantagem a captura de diferentes significados de experiências vividas no ambiente escolar, de modo a auxiliar a compreensão das relações entre os indivíduos, seu contexto e suas ações. Em relação às dificuldades enfrentadas pelos pesquisadores qualitativos, André (1983) aponta que, em geral, o investigador fica sobrecarregado nos diferentes estágios da pesquisa, pela variedade de aspectos do fenômeno a ser estudado, pela grande quantidade de dados coletados, pelo tempo necessário ao registro e transcrição das observações e pela dificuldade de codificar e interpretar os dados e apresentar os resultados.

A pesquisa qualitativa tem como identidade principal, segundo Ramires e Pessôa (2013), o reconhecimento da existência de uma relação dinâmica entre o mundo real e o sujeito, de uma interdependência viva entre sujeito e objeto e de uma postura interpretativa, constituindo-se como um campo de atividade que possui conflitos e tensões internas.

Chizzotti (2003) faz um apanhado sobre a tradição da pesquisa qualitativa e aponta cinco marcos na história desta abordagem. 0 primeiro momento, que se inicia no final do século XIX; o segundo período, que data do início do século XX; o terceiro, que vai dos anos 1940 até início dos anos 1970; o quarto, dos anos 1970 aos anos 1980; e o quinto e último, que vai dos anos 1990 até os dias atuais.

Ao tratar da pesquisa qualitativa nas pesquisas sobre ensino de Geografia no Brasil, Pinheiro (2005 a) identifica diferentes tipos de pesquisa onde empregam-se a referida abordagem. Na Tabela 1 descreve-se a tipologia de pesquisa identificada pelo autor, bem como o quantitativo das mesmas.

Tabela 1- Tipologias de pesquisa sobre ensino de Geografia no Brasil.

\begin{tabular}{|c|c|}
\hline Tipos de Pesquisa: por gênero & Quantidade \\
\hline Análise de conteúdo & 103 \\
\hline Estudo de caso & 84 \\
\hline Pesquisa correlacional & 35 \\
\hline Relato de Experiência & 33 \\
\hline Análise bibliográfica ou documental & 27 \\
\hline Pesquisa-ação & 24 \\
\hline Experimental & 11 \\
\hline TOTAL & 317 \\
\hline
\end{tabular}

Fonte: Pinheiro (2005 a). Organização dos autores. 


\subsection{A PESQUISA-AÇÃO COMO PROCEDIMENTO DE INVESTIGAÇÃO}

Diversos autores, dentre eles Engel (2000), Tripp (2005), Franco (2005), Miranda e Resende (2006), Koerich et. al. (2009), concordam que os trabalhos de pesquisa-ação se iniciaram com Lewin (1946). Esse tipo de pesquisa começou a ser desenvolvida e aplicada e teve sua práxis de forma impactante nos anos de 1960, com forte intervenção social e política, no contexto das lutas sociais e da libertação do indivíduo, ou do grupo social no qual o indivíduo está inserido, com forte mobilização para que a ação alcançasse o êxito esperado. Isso quer dizer que o indivíduo seria libertado do dogmatismo político ou religioso, discutindo as causas principais que os afetavam, buscando uma ação libertadora.

Miranda e Resende (2006) colocam a trajetória da pesquisa-ação com início nos anos 40 do século passado até o presente momento. As autoras situam a pesquisa em dois momentos. 0 primeiro, de vertente mais próxima à norte-americana, creditado aos trabalhos de Kurt Lewin iniciados antes da Segunda Guerra Mundial indo até final da década de 1960. 0 segundo, de abordagem europeia, australiana e canadense, que vai do final dos anos 1960 aos dias atuais. Trata-se, na verdade, de um grande mosaico de concepções de pesquisa-ação, cuja abordagem qualitativa nas ciências sociais terá seu conceito, justificativa e explicitação metodológica constituídos a partir de distintas vinculações teóricometodológicas.

As autoras afirmam que, nas abordagens francesa e canadense, destacam-se respectivamente os trabalhos de Barbier (2002) e André Morin (2004); ao passo que, da abordagem australiana, os principais expoentes são Wilfred Carr e Stephen Kemmis (1988). No entanto, Franco (2005) destaca que a pesquisa-ação sofreu modificações estruturais a partir da década de 1980, quando absorve os pressupostos da perspectiva dialética, através da incorporação dos fundamentos da teoria crítica de Habermas, e assume como finalidade a melhoria da prática educativa docente.

Nesse sentido, a pesquisa (e o pesquisador) precisa clarear os objetivos, as implicações possíveis na ação e radicalizar a democratização da construção do saber. Também é preciso ter um compromisso claro com a verdade conhecida e apreendida pelos sujeitos que se relacionam com a situação investigada. Neste intuito, Thiollent (2011) diz que "Toda pesquisa-ação possui um caráter participativo, pelo fato de promover ampla interação entre pesquisadores e membros representativos da situação investigada. Nela existe vontade de ação planejada sobre os problemas detectados na fase investigada" (p. 21).

A pesquisa-ação é aquela em que o pesquisador além de compreender, visa intervir na situação, com o objetivo de modificá-la. 0 conhecimento articula-se a uma finalidade intencional de alteração da situação pesquisada. Assim, ao mesmo tempo em que realiza o diagnóstico e a análise de uma determinada situação, a pesquisa-ação propõe ao conjunto de sujeitos envolvidos mudanças que levem ao aprimoramento das práticas analisadas (SEVERINO, 2007).

Define Thiollent (2011):

A pesquisa ação é um tipo de investigação social com base empírica que é concebida e realizada em estreita associação com uma ação ou com a resolução de um problema coletivo no qual os pesquisadores e os participantes representativos da situação ou do problema estão envolvidos de modo cooperativo ou participativo.

Por sua vez, Fonseca $(2002,34-5)$ precisa:

A pesquisa-ação pressupõe uma participação planejada do pesquisador na situação problemática a ser investigada. 0 processo de pesquisa recorre a uma metodologia sistemática, no sentido de transformar as realidades observadas, a partir da sua compreensão, conhecimento e compromisso para a ação dos elementos envolvidos na pesquisa. 0 objeto da pesquisa-ação é uma situação social situada em conjunto e não um conjunto de variáveis isoladas que se poderiam analisar independentemente do resto. Os dados recolhidos no decurso do trabalho não têm valor significativo em si, interessando enquanto elementos de um processo de mudança social. 0 investigador abandona o papel de observador em proveito de uma atitude participativa e de uma relação sujeito a sujeito com os outros parceiros. 0 pesquisador quando participa na ação traz consigo uma série de conhecimentos que serão o substrato para a realização da sua análise reflexiva sobre a realidade e os 
elementos que a integram. A reflexão sobre a prática implica em modificações no conhecimento do pesquisador.

Para Gil (2007), a pesquisa-ação tem sido alvo de controvérsia devido ao envolvimento ativo do pesquisador e à ação por parte das pessoas ou grupos envolvidos no problema. Apesar das críticas, essa modalidade de pesquisa tem sido usada por pesquisadores identificados pelas ideologias reformistas e participativas. Nesse sentido, Franco (2005) trabalha a pesquisa-ação numa vertente crítica e para ela a condição para ser pesquisa-ação crítica é o mergulho nas práxis do grupo social em estudo, do qual se extraem as perspectivas latentes, o oculto, o não familiar que sustentam as práticas, sendo as mudanças negociadas e geridas no coletivo.

A pesquisa-ação crítica considera a voz do sujeito, sua perspectiva, seu sentido, mas não apenas para registro e posterior interpretação do pesquisador: a voz do sujeito fará parte da tessitura da metodologia da investigação. Nesse caso, a metodologia não se faz por meio das etapas de um método, mas se organiza pelas situações relevantes que emergem do processo. Franco (2005) aponta que tem observado três conceituações diferentes em trabalhos de pesquisa-ação no Brasil, das quais será citada apenas a segunda, por ser a que mais se aproxima dos objetivos deste trabalho:

[...] se essa transformação é percebida como necessária a partir dos trabalhos iniciais do pesquisador com o grupo, decorrente de um processo que valoriza a construção cognitiva da experiência, sustentada por reflexão crítica coletiva, com vistas a emancipação dos sujeitos e das condições que o coletivo considera opressivas, essa pesquisa vai assumindo o caráter de criticidade e, então, tem se utilizado a conceituação de pesquisa-ação crítica. (FRANCO, 2005)

Miranda e Resende (2006) expõem que, em uma perspectiva vinculada a Jürgen Habermas, os australianos Carr e Kemmis (1988, p. 142-143), ao formularem sua concepção de pesquisa-ação na educação, defendem que a teoria educativa deve corresponder a cinco exigências:

a) rejeitar as noções positivistas de racionalidade, de objetividade e de verdade;

b) admitir a possibilidade de utilizar as categorias interpretativas dos docentes;

c) encontrar meios para distinguir as interpretações que estão ideologicamente distorcidas das que não estão devendo proporcionar também alguma orientação sobre como superar os auto-entendimentos distorcidos;

d) preocupar-se em identificar aspectos da ordem social existente que frustram a obtenção dos fins racionais, devendo poder oferecer explicações teóricas mediante as quais os docentes vejam como eliminar ou superar tais aspectos;

e) reconhecer que a teoria educativa é prática no sentido de que a questão de sua consideração educacional seja determinada pela maneira pela qual se relaciona com a prática.

Para as autoras, a verdadeira finalidade da teoria educativa seria informar e guiar a prática dos educadores, indicando quais ações devem empreender se querem superar os problemas e eliminar as dificuldades. Afirmam ainda, que se deve insistir no risco de fazer com que a pesquisa-ação seja convertida em estratégia de políticas com a finalidade de imprimir reformas no campo da retórica e da ação do professor, quando a sua discussão epistemológica e conceitual se transforme então em normalizações instituidoras da prática docente.

Com relação aos procedimentos e etapas da pesquisa-ação, Franco (2005) menciona as etapas definidas por Lewin (1946), sendo que a primeira fase é o planejamento, que envolve reconhecimento da situação e elaboração de um diagnóstico, a segunda fase é a tomada de decisão e a terceira é o encontro de fatos sobre os resultados da ação.

Baldissera (2012) ressalta que a pesquisa-ação como método de investigação agrega algumas técnicas de pesquisa comuns às ciências sociais. Utilizam-se de técnicas de coleta e interpretação dos dados, de intervenção na solução de problemas e organização de ações, bem como de técnicas e dinâmicas de grupo para trabalhar com a dimensão coletiva e interativa na produção do conhecimento e programação da ação coletiva.

Na década de 1960, nos estudos na área de Sociologia, rapidamente ganhou terreno a ideia de que o cientista social deveria sair de seu isolamento, assumindo as consequências dos resultados de suas 
pesquisas e colocá-los em prática, para inferir no curso dos acontecimentos. Além da Sociologia e da Psicologia, a pesquisa-ação é hoje amplamente aplicada também na área do ensino.

Nos estudos iniciais da pesquisa-ação, a teoria e a prática não eram percebidas como integrantes da vida profissional de um professor. Atualmente, esse tipo de estudo começa a ser implementado com a intenção de ajudar aos professores na solução de seus problemas em sala de aula, envolvendo-os na investigação. A pesquisa-ação em sala de aula também tem se revelado como um instrumento eficiente para o desenvolvimento profissional dos professores (ENGEL, 2000).

O autor destaca que, no ensino, a pesquisa-ação tem por objeto as ações humanas em situações que são percebidas pelo professor como sendo inaceitáveis sob certos aspectos, que são suscetíveis de mudança e que, portanto, exigem uma resposta prática. Já a situação problemática é interpretada a partir do ponto de vista das pessoas envolvidas, baseando-se, portanto, sobre as representações que os diversos atores têm da situação.

A pesquisa-ação, enquanto ferramenta metodológica realizada por meio do agir comunicativo e participativo, favorece o compartilhamento de saberes entre a universidade e a escola, além de tecer uma estrutura relacional de confiança e comprometimento com os sujeitos que integram a realidade a ser transformada.

A pesquisa-ação agrega discussões e explicações e possibilita gerar um conhecimento descritivo e mais crítico acerca das situações vivenciadas nos espaços organizacionais e sociais. Possibilita ainda a expressão e reflexão a respeito dos significados e sentimentos dos participantes e seus pares, atribuídos ao processo de avaliação de desempenho.

A pesquisa-ação constitui em uma importante ferramenta metodológica pelo fato da mesma não se sustentar em epistemologias positivistas e lineares, mas em abordagens que pressupõem a integração dialógica entre os sujeitos e sua existência, entre os fatos e valores, entre teoria e ação e, principalmente, entre pesquisador e pesquisado e o mais importante, os resultados sempre visam à melhoria do problema pesquisado.

\subsection{OS PROCEDIMENTOS DE COLETA DE DADOS}

O levantamento bibliográfico, com vista ao enriquecimento do marco teórico da pesquisa, constitui a análise de estudos anteriores sobre a mesma temática investigada ou temas correlatos. Alves-Mazzotti e Gewandsnajder (2000) diferenciam dois tipos de levantamento bibliográfico, sendo: aquele do qual o pesquisador necessita para seu próprio consumo, isto é, para ter clareza sobre as principais questões teórico-metodológicas pertinentes ao tema escolhido, e um outro que vai de fato integrar os resultados da pesquisa.

Em suma, o levantamento bibliográfico nada mais é que um empreendimento no sentido de adquirir familiaridade com o estado do conhecimento na área, que torna o pesquisador capaz de problematizar o tema e de indicar a contribuição que seu estudo pretende trazer a expansão do conhecimento. Auxilia também na definição das categorias de análise e categorias de investigação, na escolha dos instrumentos de coletas adequados e bem amarrados com a realidade do objeto de investigação.

O levantamento documental constitui basicamente na busca de informações documentais com vista ao enriquecimento da pesquisa. Em geral, é muito semelhante ao levantamento bibliográfico; o que difere é que, na busca por fontes documentais, não se refere apenas a documentos impressos. Nesse sentido, Fonseca (2002) esclarece que o levantamento documental recorre a fontes mais diversificadas, tais como: jornais, revistas, relatórios, documentos oficiais, cartas, filmes, fotografias, pinturas, gravuras, dentre uma infinidade de outras fontes.

O levantamento documental que alimentou a presente pesquisa tem como base inicial os PCN dos anos finais do ensino fundamental de 1998, seguido da análise das Diretrizes Curriculares Nacionais para o Ensino Fundamental de 9 (nove) anos, de 2010, o Referencial Curricular para o Ensino de Geografia do 6o ao 9o ano, elaborado pelo estado do Maranhão, de 2010, e o Plano Municipal de Educação de ImperatrizMA, de 2014.

Os espaços de pesquisa são as escolas municipais da cidade de Imperatriz-MA. Como recorte, a investigação foi feita somente nas escolas municipais, descartando assim as escolas alugadas e conveniadas, por considerar que somente nas escolas municipais há processo democrático de escolha dos gestores. Considerando o nível de ensino abordado na pesquisa, que é do 6o ao 9o ano do ensino 
fundamental, existem 88 escolas que trabalham com esse nível de ensino, das quais somente 26 são municipais, enquanto as demais funcionam em prédios alugados. Nesses estabelecimentos, não existe escolha dos gestores, visto que, em geral, os gestores são os donos do prédio onde funciona a escola.

0 trabalho de campo foi realizado durante três semestres letivos. Teve início no segundo semestre de 2015, com o cadastro e seleção das escolas municipais com a oferta dos anos finais do ensino fundamental, seguido da aplicação do questionário com os professores lotados para ministrarem aulas de Geografia. 0 próximo passou foi a realização de um curso teórico sobre a Teoria da Ação Comunicativa para os professores selecionados a participarem da pesquisa. No primeiro semestre de 2016, foram realizadas as entrevistas e elaborado o plano de ação para as escolas e, no segundo semestre do mesmo ano, foi desenvolvido o plano de ação e feito a avaliação do mesmo.

No entanto, foram aplicados questionários em apenas 15 das 26 escolas municipais. 0 motivo de 0 questionário ter sido aplicado apenas nesse número de escolas foi o fato de que nas demais unidades não havia professor lotado para ministrar aula de Geografia. Para cada série/ano havia um professor diferente, isso porque os professores dos demais componentes curriculares não completavam suas cargas horárias, o que fazia com que utilizassem o componente de Geografia para tanto. Assim, aplicou-se o questionário apenas nas escolas onde havia professores lotados para ministrarem aulas de Geografia.

Um pouco sobre as escolas municipais em Imperatriz-MA. Segundo dados do plano municipal de educação, existem 26 (vinte e seis) escolas municipais na cidade de Imperatriz, o que equivale a 30\% do total das escolas municipais ver tabela 2 .

Tabela 2 - Quantitativo de escolas municipais e privadas que ofertam o ensino fundamental no município de Imperatriz-MA

\begin{tabular}{|c|c|c|c|c|}
\hline \multirow{2}{*}{ Rede de Ensino } & \multicolumn{2}{|c|}{ Zona urbana } & \multirow{2}{*}{$\begin{array}{c}\text { Zona Rural } \\
\text { Prédios próprios }\end{array}$} & \multirow{2}{*}{ Total } \\
\hline & Prédios próprios & Prédios alugados & & \\
\hline Rede Municipal & 26 & 62 & 32 & 120 \\
\hline Rede Privada & \multicolumn{2}{|c|}{37} & - & 37 \\
\hline
\end{tabular}

Das 26 escolas municipais mencionadas na tabela acima e relacionadas no ANEXO C, apenas 15 têm professores de Geografia lotados na escola. Nas demais, o componente curricular Geografia é distribuído entre os professores que não completaram suas cargas horárias e acabam trabalhando com a disciplina sem a devida qualificação para tal. No caso das escolas onde não havia professores responsáveis pelo componente curricular Geografia não foi recolhido o questionário. Na Figura 4 constam as 15 escolas onde foram recolhidos os questionários.

Figura 4 - Localização das 15 Escolas da fase inicial da pesquisa.

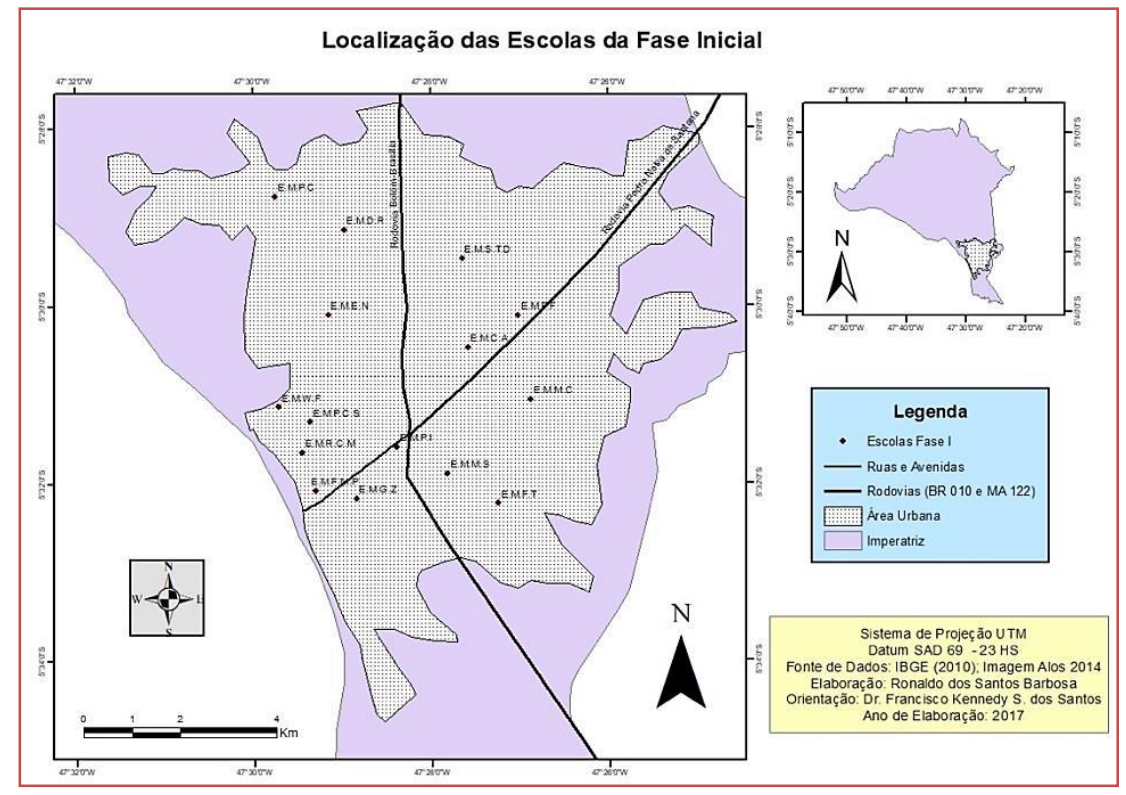

Fonte: Elaboração dos autores (2017). 
No quadro abaixo constam as escolas que tinham professores lotados na disciplina de Geografia. A sigla QE significa questionário entregue e QR questionário recolhido.

Quadro 1 - Escolas municipais onde os professores responderam o questionário

\begin{tabular}{|c|l|c|c|}
\hline \multicolumn{1}{|c|}{ № } & \multicolumn{1}{|c|}{ QE } & QR \\
\hline 1 & Escola Municipal Castro Alves & 4 & 4 \\
\hline 2 & Escola Municipal Morada do Sol & 2 & 2 \\
\hline 3 & Escola Municipal Darcy Ribeiro & 2 & 2 \\
\hline 4 & Escola Municipal Eliza Nunes & 2 & 2 \\
\hline 5 & Escola Municipal Frei Manoel Procópio & 2 & 2 \\
\hline 6 & Escola Municipal Frei Tadeu & 3 & 3 \\
\hline 7 & Escola Municipal Giovanni Zanni & 1 & 1 \\
\hline 8 & Escola Municipal Madalena de Canossa & 2 & 2 \\
\hline 9 & Escola Municipal Parsondas de Carvalho & 2 & 2 \\
\hline 10 & Escola Municipal Presidente Costa e Silva & 2 & 2 \\
\hline 11 & Escola Municipal Princesa Isabel & 2 & 2 \\
\hline 12 & Escola Municipal Renato Cortez Moreira & 2 & 2 \\
\hline 13 & Escola Municipal Santa Tereza D'Ávila & 34 & 34 \\
\hline 14 & Escola Municipal Wady Fiquene & 2 & 2 \\
\hline 15 & Escola Municipal Paulo Freire & 2 & 2 \\
\hline & & & 2 \\
\hline
\end{tabular}

Fonte: Trabalho de Campo (2015).

Após o recolhimento dos questionários, deu-se início o processo de seleção das escolas para o aprofundamento da investigação. Foram escolhidas as escolas municipais pelo fato de haver eleição para gestores, o que não ocorre nas escolas alugadas ou conveniadas. Acredita-se que nas escolas onde existe o processo democrático de escolha dos gestores, os mecanismos de tomada de decisões ocorram de forma comunicativa, permitindo aos professores e membros do conselho escolar oportunidades de argumentação nas tomadas de decisões.

Outros critérios foram a existência de conselho escolar atuante, participação nas avaliações do IDEB 2013 e 2015, além de ter professores que escolheram participar da pesquisa assinalado no questionário entregue aos docentes. Após a análise dos critérios mencionados, fez-se a seleção de cinco escolas municipais para continuação da investigação. A análise foi feita em cinco escolas municipais da cidade de Imperatriz-MA, selecionadas obedecendo alguns critérios tais como: ser municipal, ofertar o ensino fundamental anos finais, ter professor lotado na disciplina de Geografia e que esse(s) professor tenha sinalizado a sua anuência em participar da pesquisa através do questionário.

Quadro 2 - Escolas municipais selecionadas e número de professores que aceitaram continuar participando da pesquisa.

\begin{tabular}{|c|l|c|c|}
\hline \multicolumn{1}{|c|}{ ESCOLA } & \multicolumn{1}{|c|}{ TURNO } & PROFESSORES \\
\hline 1 & Escola Municipal Paulo Freire & Matutino & 1 \\
\hline 2 & Escola Municipal Frei Tadeu & Mat. e Vesp. & 2 \\
\hline 3 & Escola Municipal Madalena de Canossa & Mespertino & 2 \\
\hline 4 & Escola Municipal Giovanni Zanni & Vesp. & 2 \\
\hline 5 & Escola Municipal Wady Fiquene & & 1 \\
\hline & TOTAL & & 08 \\
\hline
\end{tabular}


Vale ressaltar que além dos oito professores de Geografia, duas pedagogas participaram da pesquisa na segunda fase, na qual estudou-se sobre a TAC.

Figura 5 - Localização das Escolas Selecionadas para a fase final da pesquisa.

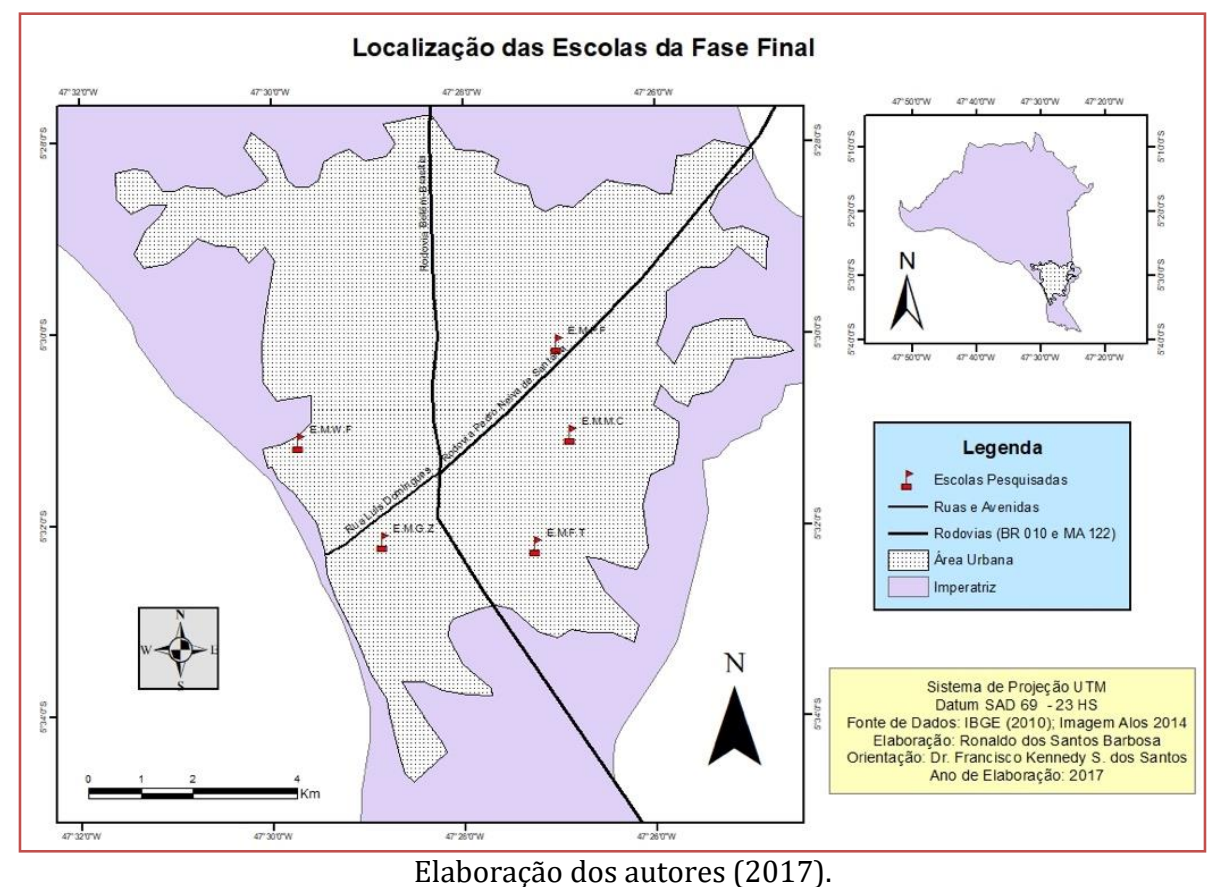

A cidade de Imperatriz conta com 88 escolas de ensino fundamental, sendo 26 escolas municipais e 62 escolas alugadas e/ou conveniadas, como visto na Figura 4. A presente pesquisa foi desenvolvida apenas nas escolas municipais, que somam um total de 26 escolas, destas apenas 15 escolas irão fazer parte diretamente da pesquisa pelo fato de oferecerem o ensino fundamental anos finais ver figura 6, pois algumas escolas oferecem apenas os anos iniciais do ensino fundamental ou não possuem professores lotados para ministrar aula de Geografia.

Dentre as 15 (quinze) escolas municipais em que foram aplicados os questionários escolheu-se cinco para o desenvolvimento da pesquisa, a escolha das escolas seguiu alguns critérios como: ser municipal; ofertar o ensino fundamental anos finais em um ou dois turnos; ter professor lotado na disciplina de Geografia; professores que aceitaram participar da pesquisa a partir do questionário; realizar eleição para escola do gestor; ter conselho escolar atuante e apresentar notas do IDEB nos anos 2011 e 2013. Segue abaixo o mapa com a localização das escolas selecionadas.

Após seleção das escolas, fez-se um levantamento de dados dessas instituições, incluindo alguns indicadores, como demonstra as tabelas abaixo, para então iniciar o trabalho com os professores. Das escolas selecionadas, apenas uma oferece o ensino fundamental anos finais em um turno (E.M Wady Fiquene) e as demais oferecem o ensino fundamental anos finais em dois turnos (matutino e vespertino).

Na Tabela 3 são apresentados alguns indicadores relevantes para compreender a realidade enfrentada pelos professores que ministram aulas nas escolas selecionadas: a quantidade de matrículas, de turmas e salas de aula. A última variável, porém, merece destaque, que é a média de alunos por sala. Embora os números aparentem estar dentro dos padrões do Instituto Nacional de Estudos e Pesquisas Educacionais Anísio Teixeira (IINEP), sabe-se que a média não representa a realidade, pois o que foi observado nas escolas pesquisadas foram as turmas de 6음 anos e 9o anos sempre lotadas com mais de 35 alunos em duas das cinco escolas. Além do elevado número de alunos, outro fator a ser considerado é a dimensão da sala de aula. Os prédios que foram construídos há mais de duas décadas têm salas muito pequenas para a quantidade de alunos. Já os prédios cuja construção é mais recente têm salas mais amplas e, portanto, suportam 35 alunos sem problema. 
Tabela 3 - Indicadores da Educação em Imperatriz

\begin{tabular}{|c|c|c|c|c|c|}
\hline Código & Escolas & Matrículas & Turmas & Salas & Densidade \\
\hline 21092508 & EM Giovanni Zanni & 320 & 13 & 8 & 25,8 \\
\hline 21092540 & EM Paulo Freire & 815 & 30 & 18 & 30,2 \\
\hline 21093172 & EM Wady Fiquene & 546 & 20 & 10 & 27,9 \\
\hline 21094225 & EM Madalena de Canossa & 893 & 27 & 12 & 37,6 \\
\hline 21264511 & EM Frei Tadeu & 667 & 22 & 12 & 38,9 \\
\hline
\end{tabular}

Fonte: IBEB (2015). Organização dos autores.

É importante citar que, ao buscar informações no portal IDEB Escola (idebescola.inep.gov.br) sobre as cinco escolas pesquisadas, as informações disponibilizadas no censo escolar de 2015 não conferiam com a realidade encontrada nas escolas. Dados como a existência de laboratórios, acesso à internet banda larga, quantidade de computadores disponível para uso dos alunos, dentre outros não eram os mesmos que aqueles verificados in loco.

Outro indicador que chamou atenção foi a projeção das metas para a nota IDEB e a nota real conferida a cada escola. A EM Giovanni Zanni, por exemplo, projetou metas muito acima das metas municipal e estadual, como pode-se observar na Tabela 4.

Tabela 4 - Dados do IDEB referente os anos de 2013, 2015 e 2017

\begin{tabular}{|c|c|c|c|c|c|c|c|}
\hline \multirow[b]{2}{*}{ Código } & \multirow[b]{2}{*}{ Escolas } & \multicolumn{5}{|c|}{ Nota IDEB } & \multirow[b]{2}{*}{$\begin{array}{l}\text { Nota } \\
2017\end{array}$} \\
\hline & & $\begin{array}{l}\text { Meta } \\
2013\end{array}$ & $\begin{array}{l}\text { Nota } \\
2013\end{array}$ & $\begin{array}{l}\text { Meta } \\
2015\end{array}$ & $\begin{array}{l}\text { Nota } \\
2015\end{array}$ & $\begin{array}{l}\text { Meta } \\
2017\end{array}$ & \\
\hline 21092508 & EM Giovanni Zanni & 5,8 & 3,7 & 6,1 & 4,1 & 6,3 & 4.8 \\
\hline 21092540 & EM Paulo Freire & 3,7 & 4,2 & 4,1 & 4,4 & 4,4 & 4.4 \\
\hline 21093172 & EM Wady Fiquene & 4,2 & 4,1 & 4,5 & 5,0 & 4,8 & 4.9 \\
\hline 21094225 & EM Madalena de Canossa & 4,0 & 3,9 & 4,4 & 4,1 & 4,6 & 4,8 \\
\hline 21264511 & EM Frei Tadeu & 3,5 & 3,8 & 3,9 & 4,4 & 4,1 & $*$ \\
\hline
\end{tabular}

Fonte: IBEB (2015). Organização dos autores.

Das escolas pesquisadas, apenas duas conseguiram atingir as metas propostas entre 2013 e 2015 como mostra a quadro 3.

Quadro 3 - Grupos de adequação da formação dos docentes em relação à disciplina que leciona.

\begin{tabular}{|c|l|}
\hline \multicolumn{1}{|c|}{ GRUPOS } & \multicolumn{1}{c|}{ DESCRIÇÃO } \\
\hline 1 & $\begin{array}{l}\text { Docentes com formação superior de licenciatura na mesma disciplina que lecionam, ou bacharelado na } \\
\text { mesma disciplina com curso de complementação pedagógica concluído. }\end{array}$ \\
\hline 2 & $\begin{array}{l}\text { Docentes com formação superior de bacharelado na disciplina correspondente, mas sem licenciatura ou } \\
\text { complementação pedagógica. }\end{array}$ \\
\hline 3 & $\begin{array}{l}\text { Docentes com licenciatura em área diferente daquela que leciona, ou com bacharelado nas disciplinas } \\
\text { da base curricular comum e complementação pedagógica concluída em área diferente daquela que } \\
\text { leciona. }\end{array}$ \\
\hline 4 & Docentes com outra formação superior não considerada nas categorias anteriores. \\
\hline 5 & Docentes que não possuem curso superior completo. \\
\hline
\end{tabular}


Os dados atestam o que foi evidenciado por Brito, Rodrigues e Barbosa (2011) exposto na introdução deste trabalho, de que na cidade de Imperatriz-MA existe uma grande quantidade de professores ministrando aula de Geografia sem a habilitação necessária, no caso, a Licenciatura em Geografia. A referida pesquisa foi desenvolvida em 2010 e 2011, e percebe-se que nada mudou até 2015, ano de realização do censo escolar.

Tabela 5 - A relação formação inicial e a prática docente.

\begin{tabular}{|c|c|c|c|c|c|c|}
\hline \multirow{2}{*}{ Código } & \multirow{2}{*}{ Escolas } & \multicolumn{5}{|c|}{ Indicador de Adequação da Formação Docente } \\
\hline & & Grupo 1 & Grupo 2 & Grupo 3 & Grupo 4 & Grupo 5 \\
\hline 21092508 & EM Giovanni Zanni & 42,9 & 0 & 26,4 & 9,9 & 20,8 \\
\hline 21092540 & EM Paulo Freire & 26,3 & 0 & 63,2 & 3,9 & 6,6 \\
\hline 21093172 & EM Wady Fiquene & 27,8 & 4,2 & 41,7 & 9,7 & 16,6 \\
\hline 21094225 & EM Madalena de Canossa & 33,1 & 3,4 & 42,1 & 9 & 12,4 \\
\hline 21264511 & EM Frei Tadeu & 23,7 & 0 & 67,1 & 0 & 9,2 \\
\hline
\end{tabular}

Fonte: INEP (2015). Organização dos autores.

$\mathrm{Na}$ tabela acima, chama-se atenção para os grupos 3 e 4, respectivamente. No grupo 3, temos os professores com diferentes formações ministrando aula de Geografia, e no grupo 5, os professores com formação superior incompleta tendo apenas o magistério em nível médio.

Um dos indicadores da educação de Imperatriz que tem merecido atenção é o nível de esforço docente. Este indicador mensura o esforço empreendido pelos professores da educação básica no exercício de sua profissão, representados no quadro abaixo.

Quadro 4 - Descrição dos níveis de esforço docente segundo INEP

\begin{tabular}{|c|c|}
\hline Níveis & Descrição \\
\hline 1 & Docente que tem até 25 alunos e atua em um único turno, escola e etapa. \\
\hline 2 & Docente que tem entre 25 e 150 alunos e atua em um único turno, escola e etapa. \\
\hline 3 & Docente que tem entre 25 e 300 alunos e atua em um ou dois turnos em uma única escola e etapa. \\
\hline 4 & $\begin{array}{l}\text { Docentes que tem entre } 50 \text { e } 400 \text { alunos e atua em dois turnos, em uma ou duas escolas e em duas } \\
\text { etapas. }\end{array}$ \\
\hline 5 & $\begin{array}{l}\text { Docente que tem mais de } 300 \text { alunos e atua nos três turnos, em duas ou três escolas e em duas etapas } \\
\text { ou três etapas. }\end{array}$ \\
\hline 6 & $\begin{array}{l}\text { Docente que tem mais de } 400 \text { alunos e atua nos três turnos, em duas ou três escolas e em duas etapas } \\
\text { ou três etapas. }\end{array}$ \\
\hline
\end{tabular}

Fonte: Nota técnica INEP no $039 / 2014$. 
Tabela 6 - A relação do nível de esforço docente.

\begin{tabular}{|l|l|c|}
\hline \multicolumn{1}{|c|}{ Código Escolas } & Nível \\
\hline 21092508 & EM Giovanni Zanni & 4 \\
\hline 21092540 & EM Paulo Freire & 6 \\
\hline 21093172 & EM Wady Fiquene & 4 \\
\hline 21094225 & EM Madalena de Canossa & 6 \\
\hline 21264511 & EM Frei Tadeu & 6 \\
\hline
\end{tabular}

Fonte: Nota técnica INEP no 039/2014.

Figura 6 - Localização dos prédios das escolas pesquisadas.

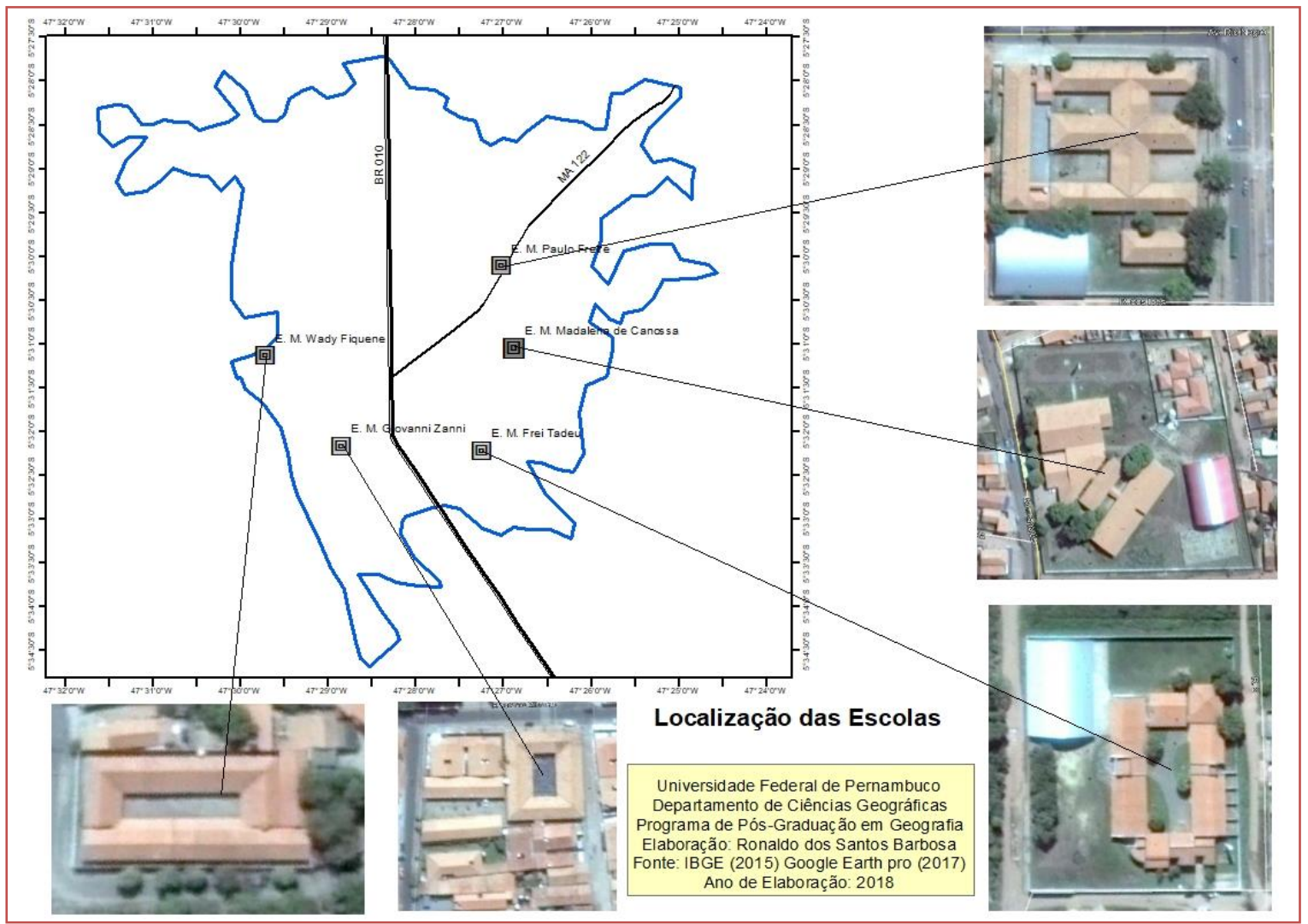

Fonte: Trabalho de campo. Organização dos autores (2018).

Constituem sujeitos da pesquisa os professores efetivos, com formação em Geografia ou não, que ministram aulas da disciplina do $6^{\circ}$ ao 90 ano nas escolas municipais de Imperatriz-MA que funcionam em prédios da prefeitura. Foram identificados 34 professores que representam o universo da pesquisa e oito professores que constituem a amostra da pesquisa.

Quadro 5 - Grupos de professores pesquisados.

\begin{tabular}{|c|c|c|}
\hline \multirow{2}{*}{ CATEGORIA } & SUBCATEGORIAS & GRUPOS \\
\multirow{2}{*}{ Professores efetivos - Pe } & Com Formação específica - CFe & Experiente - Ex \\
\cline { 2 - 3 } & Sem Formação específica - SFe & Iniciante - In \\
\cline { 2 - 3 } & & Experiente - Ex \\
\hline
\end{tabular}

Fonte: Trabalho de Campo. Organização dos autores. 


\subsection{ETAPAS DA INVESTIGAÇÃO}

\subsubsection{PRIMEIRA ETAPA}

Elaboração e aplicação de questionários: Sobre o questionário, segundo Rodríguez et al. (1999), não se pode dizer que seja uma das técnicas mais representativas na investigação qualitativa, pois a sua utilização está mais associada a técnicas de investigação quantitativa. Contudo, enquanto técnica de recolha de dados, pode prestar um importante serviço à investigação qualitativa. Essa técnica baseia-se na criação de um formulário, previamente elaborado e normalizado.

O questionário foi aplicado em 15 escolas a todos os professores de Geografia do 6o ao 9o ano das escolas municipais da cidade de Imperatriz, que totalizaram 34 professores. A seleção da amostra não foi probabilista, uma vez que, em pesquisas de abordagem qualitativa, a amostragem é feita pelo grau de relevância do sujeito e não pela quantidade dos sujeitos. No caso deste trabalho, ao responder o questionário, o sujeito declarava se tinha interesse ou não de participar das demais etapas (curso teórico, entrevista e plano de ação).

\subsubsection{SEGUNDA ETAPA}

Aproximação com o pensamento de Habermas por meio de estudos teóricos sobre os pressupostos da TAC. Nesta etapa da pesquisa participaram nove professores e duas pedagogas. Utilizou-se a técnica do grupo focal para orientar a dinâmica dos encontros, que totalizaram seis. Os encontros aconteceram no Laboratório de Cartografia e Ensino (LabCartE) da Universidade Estadual do Maranhão, Campus de Imperatriz.

\section{Quadro 6 - Cronograma do Curso Teórico}

\begin{tabular}{|c|l|l|}
\hline ENCONTROS & \multicolumn{1}{|c|}{ TEMÁTICA } & \multicolumn{1}{|c|}{ PARTICIPANTES } \\
\hline Primeiro Encontro & Apresentação do Projeto & $\begin{array}{l}\text { Professores e pedagogas de duas } \\
\text { escolas }\end{array}$ \\
\hline Segundo Encontro & Capítulo I - do livro de Boufleuer (2001) & $\begin{array}{l}\text { Professores e pedagogas de duas } \\
\text { escolas }\end{array}$ \\
\hline Terceiro Encontro & Capítulo IV - do livro de Boufleuer (2001) & $\begin{array}{l}\text { Professores e pedagogas de duas } \\
\text { escolas }\end{array}$ \\
\hline Quarto Encontro & Capítulo V - do livro de Boufleuer (2001) & $\begin{array}{l}\text { Professores e pedagogas de duas } \\
\text { escolas }\end{array}$ \\
\hline Quinto Encontro & Capítulo VI - do livro de Boufleuer (2001) & $\begin{array}{l}\text { Professores e pedagogas de duas } \\
\text { escolas }\end{array}$ \\
\hline Sexto Encontro & Capítulo VII - do livro de Boufleuer (2001) & $\begin{array}{l}\text { Professores e pedagogas de duas } \\
\text { escolas }\end{array}$ \\
\hline
\end{tabular}

Fonte: Trabalho de Campo. Organização dos autores.

Foram realizadas seis sessões com um grupo de nove professores e duas pedagogas. Uma professora teve que deixar o grupo em função da aprovação no mestrado e a consequente necessidade de se ausentar. As sessões aconteceram no LabCartE (Laboratório de Cartografia e Ensino) da Universidade Estadual do Maranhão (UEMA) atual Universidade Estadual da Região Tocantina do Maranhão (UEMASUL).

O grupo focal pode ser entendido, segundo Morgan (1997), como uma técnica de pesquisa qualitativa que coleta dados por meio das interações entre sujeitos, ao se discutir um tópico sugerido pelo grupo ou pelo moderador. Para Veiga e Gondim (2001), o grupo focal também pode ser caracterizado como um recurso para compreender o processo de construção das percepções, atitudes e representações de grupos humanos.

A intenção neste trabalho foi de apresentar o pensamento de Habermas ao grupo de professores e pedagogas, além de ouvir as dúvidas e contribuições dos participantes. A escolha do material teórico foi feita pelo moderador e pelas pedagogas. Foram selecionados dois livros e desses escolhidos alguns capítulos para compor o cronograma dos encontros, como mostra no quadro abaixo. 
Quadro 7 - Cronograma das sessões do grupo focal.

\begin{tabular}{|c|l|l|}
\hline SESSÕES & \multicolumn{2}{|c|}{ TEMÁTICAS } \\
\hline Primeira & $\begin{array}{l}\text { Apresentação do projeto “Habermas e } \\
\text { a Linguagem Cartográfica em Sala de } \\
\text { Aula”. }\end{array}$ & $\begin{array}{l}\text { BARBOSA, R, dos S. Hebermas e Linguagem Cartográfica } \\
\text { em sala de aula. Projeto de Extensão com interface à } \\
\text { pesquisa. São Luís: FAPEMA, 2014. }\end{array}$ \\
\hline Segunda & $\begin{array}{l}\text { Conhecendo as categorias do } \\
\text { pensamento de Habermas. }\end{array}$ & $\begin{array}{l}\text { BOUFLEUER, J. P. Pedagogia da ação comunicativa: uma } \\
\text { leitura de Habermas. 3. ed. Ijuí, RS: EdUnijuí, 2001. Cap. 1. }\end{array}$ \\
\hline Terceira & $\begin{array}{l}\text { O conhecimento em sua estrutura } \\
\text { Comunicativa. }\end{array}$ & $\begin{array}{l}\text { BOUFLEUER, J. P. Pedagogia da ação comunicativa: uma } \\
\text { leitura de Habermas. 3. ed. Ijuí, RS: EdUnijuí, 2001. Cap. 4 }\end{array}$ \\
\hline Quinta & $\begin{array}{l}\text { Os processos pedagógicos de } \\
\text { aprendizagem orientados pela } \\
\text { racionalidade comunicativa. }\end{array}$ & $\begin{array}{l}\text { BOUFLEUER, J. P. Pedagogia da ação comunicativa: uma } \\
\text { leitura de Habermas. 3. ed. Ijuí, RS: EdUnijuí, 2001. Cap. 5. }\end{array}$ \\
\hline A TAC no âmbito da sala de aula. & $\begin{array}{l}\text { BOUFLEUER, J. P. Pedagogia da ação comunicativa: uma } \\
\text { leitura de Habermas. 3. ed. Ijuí, RS: EdUnijuí, 2001. Cap. 6. }\end{array}$ \\
& A TAC no âmbito da escola & $\begin{array}{l}\text { BOUFLEUER, J. P. Pedagogia da ação comunicativa: uma } \\
\text { leitura de Habermas. 3. ed. Ijuí, RS: EdUnijuí, 2001. Cap. 7. } \\
\text { ALARCÃO, I. Escola reflexiva e nova racionalidade. Porto } \\
\text { Alegre: Artmed, 2001. Cap. 1 e 3. }\end{array}$ \\
\hline
\end{tabular}

Fonte: Trabalho de Campo. Organização dos autores.

0 tempo de duração das sessões era de uma hora aproximadamente. No início de cada sessão, com exceção da primeira, um membro do grupo fazia a memória do encontro anterior de forma breve e um outro membro fazia apresentação da temática a ser discutida naquele encontro. Chamamos a primeira técnica de "memória" e a segunda de "introdução".

Além dos participantes (professores e as pedagogas) o grupo contou com um moderador e um observador. 0 papel do moderador era de conduzir a discussão durante o encontro e o papel do observador era de fazer anotações sobre falas e possíveis comportamentos dos participantes. Ao final de cada encontro, as anotações eram discutidas entre o moderador e o observador.

\subsubsection{TERCEIRA ETAPA}

Realização da entrevista com os professores que ministram aulas de Geografia nas cinco escolas selecionadas. A entrevista é uma das fontes de informação mais importantes e essenciais nas pesquisas que utilizam a abordagem qualitativa. Conforme Fontana e Frey (1994), entrevistar é uma das formas mais comuns e poderosas de tentar compreender outros seres humanos. A entrevista é um ótimo instrumento para captar a diversidade de descrições e interpretações que as pessoas têm sobre a realidade.

0 investigador qualitativo tem, na entrevista, um instrumento adequado para captar essas realidades múltiplas (STAKE, 1999). Assim sendo, a entrevista é considerada uma interação verbal entre, pelo menos, duas pessoas: o entrevistador, que solicita informações, e o entrevistado, que fornece respostas, das quais o primeiro, a partir de uma sistematização e interpretação adequada, poderá extrair conclusões sobre o estudo em causa.

No presente estudo optou-se por trabalhar com a entrevista semiestruturada. Nesse tipo de entrevista, o entrevistador estabelece os âmbitos sobre os quais incidem as questões. Como referem Vázquez e Angulo (2003), comparadas com as entrevistas estruturadas, as semiestruturadas não pressupõem uma especificação verbal ou escrita do tipo de perguntas a serem formuladas nem, necessariamente, da ordem de formulação. Além de possuírem características diferentes, Flick (2009) aponta também algumas vantagens das entrevistas semiestruturadas sobre as estruturadas, dado que essas últimas limitam o ponto de vista do sujeito ao impor quando, em que sequência e como tratar os assuntos.

As entrevistas semiestruturadas combinam perguntas abertas e fechadas, nas quais o informante tem a possibilidade de discorrer sobre o tema proposto. 0 pesquisador deve seguir um conjunto de questões previamente definidas, mas ele o faz em um contexto muito semelhante ao de uma conversa informal. 0 entrevistador deve ficar atento para dirigir, no momento em que achar oportuno, a discussão para o assunto que o interessa, fazendo perguntas adicionais para elucidar questões que não ficaram claras ou 
ajudar a recompor o contexto da entrevista, caso o informante tenha "fugido" ao tema ou tenha dificuldades com ele. Esse tipo de entrevista é muito utilizado quando se deseja delimitar o volume das informações, obtendo assim um direcionamento maior para o tema, intervindo a fim de que os objetivos sejam alcançados.

Para a pesquisa, a entrevista foi realizada com a amostra selecionada de oito professores a partir da aplicação dos questionários e teve como objetivo a seleção dos professores para a observação de suas práticas. Para definir a amostra da entrevista foram selecionados apenas os professores efetivos com ou sem formação em Geografia, que fossem iniciantes ou experientes. Vale ressaltar que os professores entrevistados são os mesmos que participaram do estudo teórico sobre a TAC. A terminologia "professores experientes" e "professores iniciantes" é uma adaptação do ciclo de vida profissional dos professores descritos por Huberman (2000).

\subsubsection{QUARTA ETAPA}

Elaboração do Plano de Ação e realização das Observações nas escolas. Nesta etapa foram utilizadas duas técnicas diferentes para a coleta de informações. A primeira foi a elaboração do plano de ação, sendo elaborado um plano para cada professor ou um plano para cada escola. A segunda foi a observação realizada nas escolas com o objetivo de acompanhar o desenvolvimento do plano de ação, bem como auxiliar os professores, caso necessário. Não foi determinado a priori uma quantidade de observações em cada escola. Houve casos em que o número de observações foi maior que em outros. Utilizou-se o caderno de campo para anotações consideradas importantes para a pesquisa.

Quadro 8 - 0 plano de ação foi definido em quatro etapas descritas no quadro abaixo.

\begin{tabular}{|l|l|l|}
\hline \multicolumn{2}{|c|}{ Etapas } & \multicolumn{1}{c|}{ Descrição } \\
\hline Diagnóstico das turmas & $\begin{array}{l}\text { Feito a partir da aplicação de um } \\
\text { questionário nas turmas em que cada } \\
\text { professor trabalhava. Elaboração conjunta. }\end{array}$ & Professores \\
\hline Planejamento de atividades & $\begin{array}{l}\text { Feito individualmente com cada professor, } \\
\text { haja vista que cada escola usava livro } \\
\text { didático diferente. }\end{array}$ & Pesquisador e professores \\
\hline Oficinas pedagógicas & Realizada nas escolas com os professores. & Professores e pesquisador \\
\hline $\begin{array}{l}\text { Execução das atividades em } \\
\text { sala de aula. }\end{array}$ & $\begin{array}{l}\text { Após as oficinas, os professores } \\
\text { executaram as atividades em sala. }\end{array}$ & Professores \\
\hline
\end{tabular}

Fonte: Trabalho de Campo. Organização dos autores.

No quadro abaixo estão descritas as etapas de desenvolvimento das atividades e os responsáveis por cada etapa. Vale ressaltar que, embora o cronograma tenha sido o mesmo para as escolas, as atividades desenvolvidas em cada uma foram diferentes, como representada no Quadro 9.

Quadro 9 - Atividades do Plano de Ação das Escolas

\begin{tabular}{|l|l|l|}
\multicolumn{2}{|c}{ № } & \multicolumn{1}{c|}{ Plano de Ação } \\
\hline 21092508 & Escola Municipal Giovanni Zanni & $\begin{array}{l}\text { Feira de Ciências: Alimentação (de onde } \\
\text { vem nosso alimento) }\end{array}$ \\
\hline 21092540 & Escola Municipal Paulo Freire & Feira de Ciências: Riacho bacuri \\
\hline 21093172 & Escola Municipal Wady Fiquene & Movimentos migratórios \\
\hline 21094225 & Escola Municipal Madalena de Canossa & Feira das Nações: África \\
\hline 21264511 & Escola Municipal Frei Tadeu & Mostra de Ciências: O relevo terrestre \\
\hline
\end{tabular}


Para Whyte (2005) a observação participante implica, necessariamente, em um processo longo. Muitas vezes, o pesquisador demora inúmeros meses para "negociar" sua entrada na área a ser observada. Uma fase exploratória é, assim, essencial para o desenrolar ulterior da pesquisa. Geralmente, as primeiras observações não são registradas, pois trata-se de um período de reconhecimento da área e dos sujeitos. 0 tempo é também um pré-requisito para os estudos que envolvem o comportamento e a ação de grupos: para se compreender a evolução do comportamento de pessoas e de grupos é necessário observá-los por um longo período e não em um único momento.

As observações realizadas nas escolas da cidade de Imperatriz ocorreram no período de 10 de fevereiro a 22 de novembro de 2016. Foram realizadas visitas semanais em cada escola, além de eventos específicos como: reunião de planejamento, reunião do conselho de classe, reunião de discussão da BNCC e reunião para escolha do livro didático.

A observação participante supõe a interação pesquisador/pesquisado. As informações que o investigador obtém, as respostas que são dadas às suas indagações, dependerão, ao final das contas, do seu comportamento e das relações que desenvolve com o grupo estudado. Uma autoanálise faz-se, portanto, necessária, e convém ser inserida na própria história da pesquisa. A presença do pesquisador tem que ser justificada (p. 301) e sua transformação em "nativo" não se verificará, ou seja, por mais que se pense inserido, sobre ele paira sempre a "curiosidade", quando não a desconfiança.

Whyte (2005) reconhece que desenvolver uma rotina de trabalho é fundamental. Para o autor, o pesquisador não deve recuar em face de um cotidiano que muitas vezes se mostra repetitivo e de dedicação intensa. Mediante notas e manutenção do diário de campo, o pesquisador se autodisciplina a observar e anotar sistematicamente. Sua presença constante no ambiente estudado contribui, por sua vez, para gerar confiança na população estudada. Cada espaço tem uma dinâmica própria, uma forma de organizar os espaços coletivos, como a sala de professores, de modo que os docentes se sintam bem neste espaço.

Durante a pesquisa, a sala de professores foi um dos espaços que permitiu fazer anotações relevantes para o estudo. Atividades como: comemoração de aniversários, encontro com alunos bolsistas do Programa Institucional de Bolsas de Iniciação à Docência (PIBID), reunião de escolha do livro didático, encontro com o(a) professor(a) de Geografia para uma conversa. Porém, cada escola organiza esse espaço de forma diferente; algumas escolas disponibilizam armário para que os professores acondicionem seus materiais, geladeira, cafeteira, televisão, ar condicionado; outras disponibilizam apenas uma mesa grande com cadeiras e um ventilador de teto. Vale ressaltar que Imperatriz é uma cidade que apresenta elevadas temperaturas durante todo o ano, com médias térmicas que variam entre $25^{\circ} \mathrm{C}$ de mínima e $35^{\circ} \mathrm{C}$ de máxima, porém entre os meses de agosto e novembro a temperatura máxima chega a $40^{\circ} \mathrm{C}$ com uma sensação térmica de $42^{\circ} \mathrm{C}$ (INMET, 2017).

Figura 7 - Médias térmicas para a cidade de Imperatriz-MA, (2010-2017).

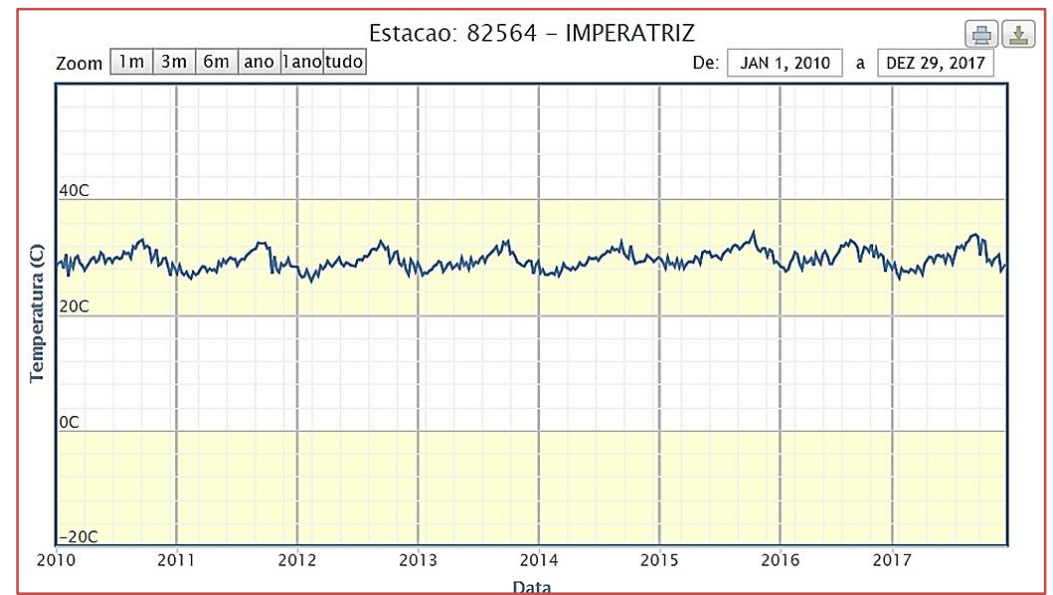

Fonte: INMET (2017) 
Para esta etapa, utilizou-se a observação participante, na qual foram observadas as práticas de oito professores no segundo semestre do ano de 2016, desde o planejamento inicial até o encerramento do ano letivo. Não foram feitas observações em sala de aula. Em geral, as observações em sala de aula provocam uma mudança no comportamento do professor bem como no comportamento dos alunos, o que pode comprometer os dados da pesquisa. Vianna (2003), ao tratar de problemas dessa natureza sugere que as observações sejam feitas várias vezes até que professor e alunos acostumem-se com a presença do pesquisador. A autora recomenda ainda que o pesquisador não faça anotações das primeiras observações por considerar que a presença do investigador cause uma alteração na dinâmica da sala de aula. Porém, não existe recomendações sobre um número mínimo ou máximo de observações a serem feitas em ambiente de pesquisa, pois acredita-se que isso dependa dos objetivos do estudo, bem como da disponibilidade do pesquisador. Vale ressaltar que, quanto maior o número de observações, mais dados e elementos o pesquisador terá para construir suas argumentações.

A observação não aconteceu só no ambiente escolar, pois considera-se que a prática docente não acontece somente na sala de aula ou na escola; ela ocorre também em espaços extraescolar, como: reuniões da categoria, reuniões da Secretaria de Educação, dentre outros. Foi utilizado nas observações o caderno de anotações (diário de bordo); os professores também receberam um caderno para fazerem anotações referentes ao plano de ação desenvolvido nas escolas. No final da pesquisa, os cadernos utilizados pelos professores foram devolvidos ao pesquisador com as anotações sobre as etapas de desenvolvimento do plano de ação.

\subsubsection{QUINTA ETAPA}

Avaliação do plano de ação. A avaliação do plano de ação constituiu um espaço de diálogo, no qual os envolvidos na pesquisa (pesquisador, professores e pedagogas) avaliaram as atividades desenvolvidas e seu impacto no cotidiano das escolas e da prática dos professores, bem como no aprendizado dos alunos. O processo de análise iniciou pela leitura de cada caderno de anotação, o que foi denominado de diário de bordo, além da realização de reunião em cada escola com coordenador pedagógico e professores participantes da pesquisa. 


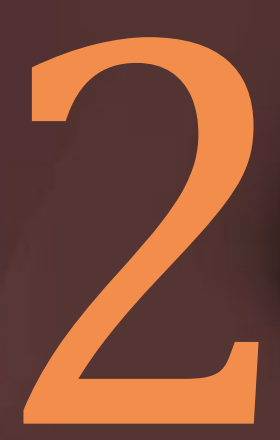

A Geografia, a Cartografia e o Ensino 
Faz parte da tradição científica, seja em momentos de investigação empírica ou de reflexão epistemológica, a busca por diferentes aportes paradigmáticos para a conexão das ideias que se faz da realidade em determinado espaço-tempo. Os diferentes paradigmas pela qual a ciência e, neste caso específico, a ciência geográfica, tem vivenciado ao longo de sua trajetória são responsáveis pelo legado de conhecimento produzido ao longo da história da Geografia Moderna.

Nesse sentido, em conformidade com o pensamento de Sposito (2001), considerando-se que um paradigma se define pelo conjunto de ideias, teorias, doutrinas e abordagens construídas com a intermediação de um método e que caracterizam uma tendência científica, pode-se afirmar também que, historicamente, houve três grandes grupos de paradigmas que foram fundamentais na orientação metodológica da produção do conhecimento geográfico, a saber: as abordagens ancoradas no Positivismo predominantes na Geografia Tradicional, no Neopositivismo, que orientou a Nova Geografia e as abordagens críticas presentes na Geografia Contemporânea. Não significa que tais paradigmas deixaram de existir ou que, o início de uma nova abordagem significa o fim de outra. Porém, é importante frisar que, a partir dos anos 80 do século passado, uma renovação na forma de produção do conhecimento geográfico apontou para uma tendência multiparadigmática ou críticas que teve seus reflexos também no ensino da Geografia.

As diferentes concepções paradigmáticas adotadas pelos geógrafos têm provocado, ao longo do tempo, tanto na universidade como na vida civil, diferenças de posturas e de ações na sua prática política, profissional e cotidiana. Essas diferenças são as demonstrações empírico-teóricas das influências que os paradigmas provocam no movimento da sociedade (SPOSITO, 2001). 0 autor destaca ainda que a relação entre as teorias e os paradigmas vigentes em determinado período da história da ciência são fundamentais para a compreensão da maneira como é proposta a interpretação das diferentes leituras que se pode fazer da realidade, porque sem esses dois elementos (a teoria e o paradigma), a ciência não se desenvolve. Partindo desse apontamento, tem-se a intenção de estabelecer um paralelo entre a produção do conhecimento na Geografia e na Cartografia e seus reflexos no ensino de Geografia durante os séculos XX e XXI.

Na trajetória da Geografia, serão abordados os termos Geografia Moderna, Nova Geografia e Geografia Contemporânea, enquanto na Cartografia serão utilizadas as denominações sugeridas por Fernández e Buchroithner (2014), com adaptações. Iniciando com a Cartografia Analítica, que foi praticada durante a Geografia Moderna e Nova Geografia e neopositivista, com atenção especial para a Linguagem Cartográfica e a Comunicação Cartográfica; em seguida com a Cartografia Crítica, que permearia o período da passagem da Nova Geografia para a Geografia Crítica, com destaque para a Visualização Cartográfica e as Novas Práticas da Cartografia; e, por fim, a Cartografia Contemporânea, que engloba as tendências pós-críticas na Geografia até os dias atuais, que compreende as últimas tendências da Cartografia no século XXI.

Parte-se, portanto, de uma análise do lugar da Cartografia no cenário da discussão histórico-temporal das correntes do pensamento geográfico, respaldados em pesquisas tipo "estado da arte" ou "estado do conhecimento" de caráter bibliográfico, para dar suporte às intervenções propostas (BRZEZINSKI; GARRIDO, 1999; FERREIRA, 2002; THERRIEN; NÓBREGA-THERRIEN, 2004). A realização de estados da arte possibilita a efetivação de balanço da pesquisa de uma determinada área de conhecimento e podem significar uma contribuição importante na constituição de seu campo teórico, pois procuram identificar os aportes significativos da construção da teoria e prática, elucidando as possíveis lacunas e ao mesmo tempo revelando experiências inovadoras investigadas que apontem alternativas de solução para os problemas da prática e reconhecimento das contribuições da pesquisa na constituição de propostas na área focalizada.

A abordagem está colocada a partir de três matrizes epistemológicas, a saber: Positivismo, neoPositivismo e a matriz contemporânea, que engloba vários paradigmas. Matrizes são as formas de pensamento que partem de um núcleo racional por meio do qual uma estrutura global emerge como discurso de mundo, uma estrutura matricial se distinguindo da outra justamente pela maneira como o intelectual vê e interliga o mundo (MOREIRA, 2008a, p. 47). Dentro de cada matriz são abordadas as correntes do pensamento geográfico desde o determinismo, passando pelo possibilismo, método regional, Geografia Quantitativa, Geografia Crítica, Humanística e Ambiental, paralelo a isso o destaque para a contribuição da Cartografia na leitura do objeto da Geografia e seus reflexos no ensino dessa disciplina. Com relação ao marco temporal, tem-se como ponto de partida o final do século XIX até os dias atuais. No tocante à abordagem dos reflexos no ensino da Geografia, esta abordagem fica restrita ao século XX, em especial a segunda metade deste século. 


\subsection{AS CORRENTES DO PENSAMENTO GEOGRÁFICO E SUA RELAÇÃO COM A CARTOGRAFIA}

Analisar as correntes do pensamento geográfico e as correntes teóricas da Cartografia não é tão fácil como aparenta, principalmente se tratando de uma análise de cunho bibliográfico, pois as obras consultadas e disponíveis não dão ênfase ao uso da Cartografia no tratamento das informações espaciais e, quando aparece tal ênfase, não se usa o mapa para representar a produção do período, portanto as abordagens ficam apenas no campo da descrição e do imaginário.

Diversas áreas do conhecimento utilizam-se do mapeamento para representar e analisar a distribuição espacial de objetos e fenômenos, contudo, o mapeamento é atividade compreendida principalmente pela Geografia e pela Cartografia. Com a diversificação e ampliação dos conteúdos e técnicas de mapeamento, a Cartografia conquistou status de disciplina independente, o que resultou na especialização das atribuições do mapa e do mapeamento na Geografia e na Cartografia. 0 espaço, embora concebido de forma diferente, está presente nas preocupações dessas duas ciências. Na Geografia ele é considerado objeto principal de análise e o seu mapeamento é parte do processo investigativo e comunicativo. Como afirma Douglas Santos (2002), o mapa é parte do discurso geográfico. Para a Cartografia, o espaço é fonte de informações para o seu objeto de estudo - o mapa. Nesse sentido, na Cartografia a ênfase está em levantar e representar as informações primárias do espaço e descobrir melhores formas para esta tarefa.

Enquanto a preocupação da Cartografia está na representação e, aí, o mapa é o fim, a Geografia se preocupa com o uso do mapa na análise do espaço geográfico e, para isso, o mapa é um meio. Todos os mapas são de interesse do geógrafo e do cartógrafo, porém, esses dois profissionais possuem habilidades e objetivos diferentes no que diz respeito a sua condição de mapeador e/ou usuário do mapa (ARCHELA; ARCHELA, 2002).

\subsection{A GEOGRAFIA MODERNA}

As pesquisas e estudos desenvolvidos no período da chamada Geografia Moderna ou tradicional tiveram como base teórico-metodológica o Positivismo. Foi uma Geografia pautada na observação e descrição de fatos, que se dividiu em duas correntes, a saber: o determinismo geográfico e o possibilismo. Moraes (1983) cita que a organização da Geografia Científica ocorreu sobre as bases do Positivismo e foi nesta concepção filosófica e metodológica que os geógrafos foram buscar as orientações para o desenvolvimento de seus estudos. Para o Positivismo, os estudos devem restringir-se ao visível, real, mensurável e palpável; como se os fenômenos se demonstrassem diretamente ao cientista, que seria um simples observador (ANDRADE, 1987). Segundo Moraes (1983), o Positivismo leva à redução da realidade ao mundo dos sentidos e, com base nele, os trabalhos científicos foram desenvolvidos a partir da aparência dos fenômenos. Nessa corrente teórica predomina a máxima de que a "Geografia é uma ciência empírica, pautada na observação". A descrição, enumeração e classificação dos fatos foram os procedimentos aos quais a Geografia Tradicional se limitou.

Na busca por bases teórico-metodológicas sobre as evidências das contribuições da Cartografia nas correntes do pensamento geográfico, é possível constatar que a produção da Geografia Brasileira é deficitária a este respeito, sendo o mapa e o mapeamento negligenciados na grande maioria das obras publicadas. Essa situação é resultado da difusão da Geografia Crítica como corrente teórica predominante no Brasil, pois essa corrente, no movimento de renovação da Geografia, associou o uso do mapa e do mapeamento unicamente aos objetivos e análise das correntes tradicional e pragmática, o que não é correto.

Assim como um texto, o mapa transmite a visão de mundo de seu autor e é, por excelência, parte do discurso geográfico e instrumento da análise geográfica. Fernández e Buchroithner (2014) destacam que nesta fase da história da Cartografia aqui chamada de Cartografia Analítica, duas tendências receberam total atenção e contribuição, que foram a linguagem cartográfica e a comunicação cartográfica. No campo da linguagem cartográfica, vale destacar o trabalho de Lech Ratajski, Joel Morrison, Aleksandr Vasmut e Jaques Bertin. Segundo os autores, foi a partir da contribuição destes teóricos que se deu a gramática do mapa (ponto, linha, área e volume) ou como se chama no Brasil, o alfabeto cartográfico. No tocante à corrente teórica da comunicação e informação cartográfica, os trabalhos de Anton Kolacny, Christopher Board, Michael Peterson, Arthur Robinson e Barbara Petchenik foram fundamentais para facilitar o processo de construção e uso do mapa.

0 determinismo, enquanto corrente do pensamento geográfico, surge final do século XIX, na Alemanha, tendo Friedrich Ratzel como pioneiro. A concepção que Ratzel tinha de Geografia foi herdada em parte de Humboldt e Ritter, porém estruturada numa visão darwinista (CLAVAL, 2006). A corrente do 
determinismo aborda as contribuições das condições naturais determinantes no comportamento e desenvolvimento do homem. Pelo fato de Ratzel apoiar suas análises na visão darwinista, ele procurou entender a difusão dos povos pela superfície terrestre, problemática que, segundo ele, articularia história, etnologia e Geografia em uma mesma discussão (MOREIRA, 2008). Para o determinismo, as diferentes formas de organização do espaço e as desigualdades existentes eram explicadas pelas condições ambientais, em especial as climáticas. Sobre esse pensar, Correa (1995) escreve:

Na Geografia, no entanto, as ideias deterministas tiveram no geógrafo alemão Ratzel seu grande organizador e divulgador, ainda que ele não tivesse sido o expoente máximo. A formação básica de Ratzel passou pela zoologia, geologia e anatomia comparada; foi aluno de Haeckel, o fundador da ecologia, que o introduziu no darwinismo (p. 10).

Para entender melhor o determinismo é importante analisar o contexto do período. Corrêa (2003) esclarece que o determinismo geográfico foi o primeiro paradigma a caracterizar a Geografia no século XIX, em razão da passagem do capitalismo de sua fase comercial para a fase monopolista. Ainda segundo o autor, o determinismo foi amplamente utilizado para justificar o processo de expansão nos continentes africano e asiático. Embora não seja possível identificar nas obras dos autores consultados tópicos específicos tratando do uso da Cartografia durante esta corrente, pode-se fazer constatações em função das características comuns que a matriz do Positivismo empregava nos estudos científicos do período, que se limitava à descrição dos espaços estudados, baseados nas observações empíricas.

A produção dos mapas na Geografia determinista era fruto de dados de distância de viagens, de contorno de litoral e de pontos de referência. A determinação e a exposição dos aspectos espaciais da realidade por meio de mapeamento foram de importância fundamental (PATTISON, 1977). Os mapas produzidos no período faziam uma mistura de visão vertical com visão oblíqua, sendo o espaço representado através da visão vertical e os objetos representados através da visão oblíqua.

A segunda corrente, o possibilismo, surge também no final do século XIX, na França, tendo Paul Vidal de La Blache como idealizador. Nesta corrente, considera-se a natureza fornecedora de possibilidades para que o homem a modificasse. 0 homem é o principal agente geográfico. Na França, La Blache passou a estudar profundamente a Geografia desenvolvida pelos alemães, principalmente os trabalhos de Ratzel, para quem dedicou profundas críticas (MOREIRA, 2008). Assim, La Blache desenvolveu outra concepção da relação "homem-meio", na qual passou a pensar a possibilidade que o homem tem de superar as imposições naturais, dependendo do nível cultural, das condições técnicas e da disposição de recursos, podendo, dessa forma, atuar sobre a natureza e modificá-la. Em uma área fisicamente delimitável eram integrados e descritos tantos os aspectos físicos como os humanos/sociais e econômicos, dando origem ao possibilismo (MORAES, 2003).

Corrêa (1986) aponta que o possibilismo, francês em sua origem, opõe-se ao determinismo ambiental germânico. Essa oposição fundamenta-se nas diferenças entre os dois países. Vale a pena ressaltar que a competitividade existente entre França e Alemanha, acirrou-se com a perda da região francesa da AlsáciaLorena para a Prússia (atual Alemanha) durante a guerra franco-prussiana (ANDRADE, 1987).

Utilizado nas escolas de Humboldt, Ritter e Ratzel, o mapa ganha destaque ainda maior com Vidal de La Blache, juntamente com as tipologias. Os estudos consistiam em um levantamento cartográfico inicial e "a conclusão em geral constituída por um conjunto de cartas, cada uma referente a um capítulo, as quais sobrepostas dariam relações entre os elementos da vida regional" (MORAES, 2003, p.78). Através da influência da proposta de La Blache, Max Sorre propõe uma metodologia de pesquisa geográfica que segue o seguinte roteiro:

[...] partia da Cartografia: a ideia de uma sobreposição de dados da observação, em um mesmo espaço, analisando historicamente a formação de cada elemento desde os naturais (solo, vegetação etc.) até os sociais (hábitos alimentares, religião etc.). Assim, se chegaria a compor, por sobreposição das informações, um quadro de situação atual, e aí se estudaria seu funcionamento, inter-relacionando os elementos presentes. (MORAES, 2003, p.81)

Observa-se que, a partir do possibilismo, a Cartografia começa a fazer parte dos estudos geográficos de modo mais efetivo, facilitando assim uma abordagem mais completa da realidade de acordo com os princípios do período, pois, a partir da espacialização das informações, era possível fazer generalizações com mais evidências. 
A terceira corrente de matriz positivista, conhecida como método regional, opõe-se às duas correntes antecedentes, visto que a diferenciação de áreas não é vista a partir das relações entre o homem e a natureza, mas sim da integração de fenômenos heterogêneos em uma dada porção da superfície da Terra. Portando, esta corrente está vinculada ao estudo de áreas e regiões, ou seja, unidades espaciais menores. Nesse sentido, Corrêa (1986) destaca que o método regional já vinha sendo estudado desde o século XVII por Varenius, passando por Kant no século XVIII e por Ritter no século XIX, e não tratava-se de algo inédito nos estudos da Geografia. Essa corrente de pensamento corroborava a necessidade de se produzir uma Geografia Regional, isto é, um conhecimento resumido sobre as diferentes áreas globais com maior nível de detalhe sobre as variáveis espaciais.

O Método Regional surge com maior força no início do século XX, a partir da década de 1930, nos Estados Unidos, tendo Richard Hartshorne como grande ícone dessa corrente. A partir da década de 1930, Hartshorne procurou trabalhar o conceito de "unidade-área" como uma parte do espaço geográfico definida pelo pesquisador em função do objeto de estudo e da escala de trabalho, cujo objetivo era a demonstração de áreas como características individuais próprias. Daí o autor propõe duas formas de abordagem, uma denominada como Geografia Idiográfica e a outra, Geografia Nomotética.

Para a Geografia Idiográfica de Hatshorne, os fenômenos variam de lugar a lugar e as suas interrelações também. Os elementos possuem relações internas e externas à área na qual estão inseridos. Nesse sentido, o processo de análise deveria integrar o maior número possível de fenômenos interrelacionados. Esse processo pode ser repetido várias vezes, até o pesquisador achar suficiente para se compreender o caráter da área enfocada. Nessa perspectiva, fazia-se uma análise singular (de um só lugar) e unitária (apreendendo vários elementos). Assim, obter-se-ia um conhecimento bastante amplo e verticalizado de determinado local.

Já na perspectiva da Geografia Nomotética realizavam-se estudos generalizados, apesar de parciais. 0 pesquisador pararia na primeira integração e a reproduziria (usando os mesmos fenômenos e mesmas interrelações) em outros lugares. Com as comparações obtidas se chegaria a um padrão de variação dos fenômenos abordados. Assim, através de comparações, obter-se-ia um conhecimento genérico. A Geografia Nomotética abriu novas vertentes no estudo geográfico, agilizando o estudo regional e criando perspectivas de planejamento e diagnósticos, além de estabelecer a possibilidade de quantificação e computação.

Mormul e Rocha (2013) apontam que, para Hartshorne, as várias partes do campo da Geografia, tais como Geografia Física, Geografia Política e Geografia Econômica foram apontadas para o tratamento especial por influência da Geografia alemã, que considerou que a Geografia se constituía enquanto ciência concreta desde que em primeiro lugar buscase compreender e explicar o mundo, todavia sem desconsiderar a descrição das totalidades como um produto do conhecimento geográfico. Assim, essa nova corrente procurou superar os limites da escola francesa, bem como do determinismo geográfico.

Rodrigues (2008) afirma que foi Hartshorne quem articulou a Geografia Geral com a Geografia Regional, diferenciando-as pelo nível de profundidade das inter-relações dos elementos estudados; quanto menor o número de elementos inter-relacionados, maior a possibilidade de generalização e, quanto maior o número de elementos inter-relacionados, mais profunda a análise, maior o conhecimento da singularidade da "área", maior a possibilidade de estudo regional. Já Christofoletti (1985) explica que o método regional considerava que cada categoria de fenômeno era objeto de determinada ciência e que caberia a estas ciências executarem as análises sobre os assuntos particulares. À Geografia, considerando a totalidade, correspondia o trabalho de síntese, reunindo e coordenando todas as informações a fim de salientar a visão global da região ou área estudada.

A ampla utilização dos mapas na Geografia Tradicional, trazida para o Brasil principalmente pelos franceses, é fruto do processo de sistematização da disciplina e do momento histórico dos seus fundadores. A busca pelo aperfeiçoamento das técnicas cartográficas foi constante na Geografia Tradicional, para a qual "o próprio desenvolvimento das técnicas de descrição e representação também foi um saldo favorável” (MORAES, 2003, p.91). A concepção de espaço estava ligada à área mapeável. Os levantamentos de informações tinham como destino o mapeamento e o cruzamento das informações eram realizados através dos mapas. Geografia e mapa eram indissociáveis para os pesquisadores dessa corrente. 


\subsection{A NOVA GEOGRAFIA}

A segunda matriz epistemológica da Geografia começa a ser construída a partir de meados da década de 1970, momento em que ocorre o processo de renovação da Geografia, principalmente porque as fundamentações teórico-metodológicas e o instrumental da Geografia Tradicional não conseguiam explicar as mudanças ocorridas na realidade pelo desenvolvimento do capitalismo. Nesse paradigma, a concepção de ciência é baseada na causalidade e na percepção empírica e utiliza, como meio de exposição, a linguagem matemática. A essas características, soma-se a (a)criticidade do investigador ou dos resultados das pesquisas. "[...] baseado nos fundamentos do neoPositivismo, teve a linguagem matemática, a neutralidade da ciência e as temáticas espaciais como suas principais características para a produção do conhecimento científico" (SPÓSITO, 2001, p. 101).

A Geografia Pragmática ou Nova Geografia, ou ainda Geografia Quantitativa, está baseada no neoPositivismo e realiza uma crítica à incapacidade da Geografia Tradicional em explicar a realidade e às características não práticas (observação e descrição) de seus estudos. 0 objetivo principal dessa nova corrente é criar uma tecnologia geográfica. As análises são baseadas em dados, o uso de modelos é amplo e o trabalho de campo é negligenciado em detrimento da análise indireta (MORAES, 2003). Compõem o conjunto metodológico da Geografia Pragmática o tratamento estatístico dos dados, o uso do computador, do sensoriamento remoto e do mapeamento automático, principalmente na elaboração de tipologias. 0 uso do mapa e dos procedimentos de mapeamento são ainda mais intensos na Geografia Pragmática, pois o advento do computador possibilitou trabalhar com mais agilidade e com um volume maior de dados. 0 processo de mapeamento se tornou mais rápido, aumentando as possibilidades de produção e reprodução de mapas. De acordo com Moraes (2003) e Fernandes (2000), as principais críticas feitas a essa corrente teórica estão direcionadas ao distanciamento da realidade através de sua matematização.

A Geografia Neopositivista, que se pautou pelo recurso aos modelos e à linguagem matemática como elementos universais da produção científica, elaborou, principalmente na década de 1970, um conhecimento padronizado e repetitivo, sem qualquer compromisso social. 0 diálogo com outros grupos da sociedade civil só se fez pelo caminho burocrático ou estatal, sem se praticar, na relação sujeito-objeto, o exercício (dedutivo ou indutivo) das relações empírico-teóricas (SPÓSITO, 2001). Essa corrente surge no século XX a partir da década de 1950, na Inglaterra, Suécia e Estados Unidos. A mesma recebe várias nominações como: Geografia Quantitativa, Geografia Teorética, Nova Geografia. Tinha como destaque o uso da matemática, da informática e da estatística. Claval (2006) cita que a partir da década de 1950, a renovação da Geografia provém cada vez mais dos programas desenvolvidos nas universidades dos EUA, da Grã-Bretanha e, em menor medida, do Norte da Europa. Isso deve-se ao papel crescente do mundo anglo saxônico em todos os domínios da vida internacional, incluindo as ciências.

Os geógrafos esperam encontrar uma ordem no mundo real. Para a descobrirem, prontificam-se a confiar nas matemáticas, que evoluíram e estão mais preparadas do que no início do século para evidenciar as sutilezas das realidades sociais. A melhoria dos procedimentos de cálculo torna mais fácil o emprego de algoritmos até então considerados demasiado complexos. Essa mutação é importante para os geógrafos. As séries corológicas que lhe interessam são tão difíceis de tratar que a única maneira de tirar partido delas era cartografá-las. Os meios de cálculo tornam possível a decomposição das séries nas suas componentes principais: em vez de acumular mapas redundantes, retém-se apenas a informação significativa (CLAVAL, 2006).

Christofoletti (1985) explica que a Geografia Quantitativa se caracterizou pelo maior rigor na aplicação da metodologia científica embasada no neoPositivismo, no uso de técnicas de estatística e matemática, na abordagem sistêmica e no uso de modelos. Santos (1986) aponta que a Nova Geografia se manifestou, sobretudo, através da quantificação e da abordagem sistêmica. Para o autor, a quantificação ocorreu em razão da procura de uma linguagem matemática que desse cientificismo à Geografia. Corrêa (2003) cita que o emprego de técnicas estatísticas como: média, desvio padrão, coeficiente de correlação, entre outros, foram muito utilizados nos estudos geográficos no período.

A década de 1970 fica marcada como o período de grandes mudanças nas ciências humanas e sociais. Na Cartografia, essas mudanças são identificadas com a criação de vários modelos de comunicação da informação cartográfica, devido ao desenvolvimento industrial nos Estados Unidos. Inicialmente, esse movimento é percebido em âmbito internacional e posteriormente no Brasil. Archela e Archela (2002) apontam que, em âmbito internacional, podem se destacar as contribuições do Soviético K. A. Salichtchev, dos Americanos A. H. Robinson, B. B. Petchenik e J. L. Morrison, do Polonês L. Ratajski, do Holandês C. Koeman e do Eslovaco A. Kolacny. 
Sob esse enfoque teórico, o mapa é considerado um veículo de informação. 0 desenvolvimento máximo desta teoria cartográfica foi atingido por Kolacny (1969). Para ele, a Cartografia é definida como teoria, técnica e prática de duas esferas de interesses: a criação e o uso de mapas. Seu modelo de comunicação cartográfica inspirou pesquisas e debates posteriores. No Brasil, Simielli (1986) analisou exaustivamente todos os modelos de comunicação apresentados até aquele momento e avaliou o mapa como meio de transmissão de informação.

Figura 8 - Organização dos Elementos da Teoria da Comunicação Cartográfica.

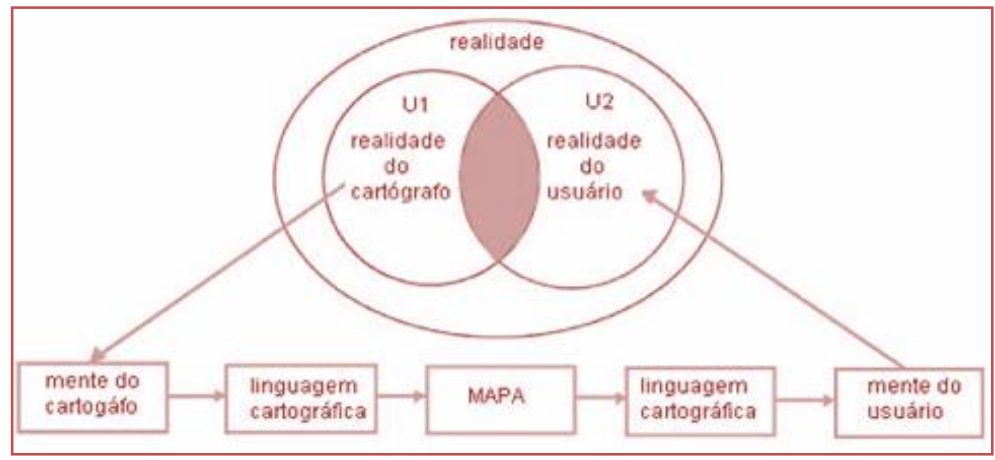

Fonte: Simieli (1987).

Embasado nesta teoria, Libault (1971) propôs um roteiro de investigação com base essencialmente cartográfica, que consiste em quatro níveis, sendo eles: compilatório, correlatório, semântico e normativo. A modelização cartográfica como base teórica foi introduzida no Brasil na década de 1970, especialmente nos trabalhos do IBGE, nas pesquisas desenvolvidas pela UNESP de Rio Claro e pela UFRJ.

Quadro 10 - Níveis de análise da informação cartográfica segundo Libault (1971).

\begin{tabular}{|c|l|}
\hline \multicolumn{2}{|c|}{ Níveis } \\
Compilatório & $\begin{array}{l}\text { Envolve o levantamento de dados que podem ser oriundos de pesquisa direta ou a } \\
\text { consulta a banco de dados. }\end{array}$ \\
\hline Correlatório & $\begin{array}{l}\text { Na análise de dados é indispensável atenção na a) homogeneidade e comparabilidade dos } \\
\text { dados; b) condições de caracterização de um fenômeno geográfico em relação aos valores } \\
\text { numéricos e em função da localização geográfica; c) a ordenação dos dados antes de } \\
\text { passar para a análise definitiva. }\end{array}$ \\
\hline Semântico & $\begin{array}{l}\text { Se busca da localização dos problemas parciais para organizar os elementos dentro de } \\
\text { um problema global, isso é a síntese, busca elaborar uma representação convencional do } \\
\text { conjunto dos resultados e haverá a necessidade de se proceder várias reduções, para } \\
\text { comunicar as soluções parciais já explicitadas. }\end{array}$ \\
\hline Normativo & $\begin{array}{l}\text { Envolve a tradução dos resultados fatoriais em normas aproveitáveis, onde haverá a } \\
\text { necessidade de organizar os dados de forma matricial. }\end{array}$ \\
\hline
\end{tabular}

Fonte: Archela e Archela (2002). Organização dos autores.

Pinheiro (2005 a) aponta que a Nova Geografia ganha destaque no Brasil principalmente em instituições públicas como o IBGE, UNESP de Rio Claro e UFRJ, aponta ainda o destaque dos trabalhos de Antonio Christofoletti na área da geomorfologia e a criação da AGETEO, em 1971. No plano do ensino de Geografia, as duas universidades citadas UNESP e UFRJ sendo que a USP também apresenta pesquisas sobre ensino só que em menor quantidade. Os estudos eram focados principalmente na análise relacionada à orientação, localização e questões cartográficas, utilizando em especial a quantificação e a pesquisa experimental. 
circula amplamente em todo o circuito escolar, mas não transita no circuito universitário. Já as ideias teórico-quantitativas circulam no circuito universitário, mas não chegam a escola. George é a referência dos manuais da escola. Mas é Christaller a referência dos manuais universitários. (MOREIRA, 2014. p. 152)

Fernández e Buchroithner (2014) reportam que, nessa fase, o foco foi dado ao processo de visualização cartográfica, o que Archela e Archela (2002) chamaram de modelização cartográfica. Autores que tiveram destaque neste período foram Alan MacEacren e David DiBiase.

\subsection{AS GEOGRAFIAS CONTEMPORÂNEAS}

Para Pinheiro (2005 b), todos os movimentos surgidos no Brasil após os anos 60 que tinham como propósito questionar as bases teórico-metodológicas da Geografia Tradicional de base positivista ou neopositivista podem ser incluídos no que se passou a conhecer como Movimento de Renovação do Pensamento Geográfico. Segundo o autor, os reflexos destas mudanças na forma de pensar a produção da Geografia Brasileira são também refletidos no ensino da Geografia Escolar, em especial nas décadas de 80 e 90 .

Esse período pode ser caracterizado pelo surgimento da Geografia Contemporânea. Para Corrêa (2011), a contemporaneidade é entendida como o tempo presente, que se estende de aproximadamente 1970 aos dias atuais. 0 autor afirma que trata-se de um período denso, no qual ocorre um combinação de características que o distingue dos períodos que o antecederam ou que irão ocorrer. Dessa forma, para atender às características da Geografia Contemporânea um só paradigma não daria conta de fazer a leitura da realidade, daí uma das características principais do momento é a pluralidade de paradigmas.

Por paradigma entende-se o conjunto de ações intelectuais que possibilitam estabelecer uma dada inteligibilidade à realidade, com base em conexões de ideias de natureza descritiva, explicativa, normativa, preditiva ou compreensiva. Nessa conexão estão diferentes relações entre sujeito do conhecimento e objeto do conhecimento. Das conexões emergem também problemáticas, questionamentos e os procedimentos operacionais. Um paradigma tem uma vertente teórico-conceitual e outra metodológica, tratando-se, em realidade, de uma matriz intelectual. Um paradigma não leva conteúdo à seleção de alguns temas e à exclusão de outros, pois cada tema é passível de ser abordado por mais de um paradigma, ainda que preferências temáticas tenham sido estabelecidas no âmbito de um dado paradigma. A reclusão de um tema em um único paradigma é um equívoco, derivado da adoção de uma visão reducionista, seja qual for o paradigma considerado (CORRÊA, 2011).

A necessidade de vários paradigmas em dar conta da leitura do espaço geográfico se justifica pela crise do paradigma fragmentário que, segundo Moreira (2008), se evidencia no decorrer dos anos 1960-1970. Embora se possa datar a nova fase dos anos 1960, é na década de 1970 que o surgimento aparece com mais evidência. $\mathrm{O}$ autor traça um panorama da Geografia nesse período e descreve novas tendências surgidas com a crise do pensamento geográfico.

É nessa década que a crise do paradigma fragmentário e físicomatemático se mostra mais visível, seja pela exacerbação do modelo, na forma da Geografia teorético-quantitativa (Corrêa, 1982), seja pela emergência de novas linhas teórico-metodológicas, na forma de uma Geografia de referência no marxismo, no subjetivismo e num ambientalismo de novo tipo. Mais recentes, e podendo-se dizer ainda nos seus primeiros ensaios, são as correntes que se referenciam na filosofia da linguagem de Ludwig Wittgenstein e Mikail Bakthin e na filosofia da complexidade de Edgar Morin, Esabelle Stengers e Henri Atlan. (MOREIRA, 2008, p. 39)

No entanto, para este trabalho será abordada apenas a Geografia Crítica apoiada no materialismo dialético, a Geografia Humanista ancorada na fenomenologia e a Geografia Ambiental, que tem usado a visão sistêmica como eixo norteador de suas pesquisas, tentando identificar o papel da Cartografia nessas correntes ao longo das duas últimas décadas do século passado e na primeira década deste século.

Parece salutar evidenciar as tendências atuais da Cartografia Contemporânea antes de abordar as tendências da Geografia. Três tendências merecem destaque nesta parte do texto, sendo a primeira o mapa como construção social, a segunda a Cybercartografia e, por fim, a Cartografia para crianças. 
No período pós Segunda Guerra Mundial se iniciou o movimento de renovação do pensamento geográfico. Isso se deu em função das condições sociais em que o mundo se encontrava, com sérios problemas de pobreza, desigualdades sociais, fome e conflitos localizados. Santos (1986) coloca que a Geografia não podia escapar às enormes transformações ocorridas em todos os domínios científicos após 1950.

[...] os geógrafos que adotaram a dialética como método, tiveram seu conhecimento produzido, excessivamente carregado pelo discurso, com forte e explícita tendência ideológica, cujas manifestações ocorreram, principalmente, no campo da política. Mesmo tendo preocupações de caráter empírico, muitos geógrafos resvalaram na vertente do discurso repetitivo, procurando nas obras de Marx o único fundamento possível para se explicar a realidade, esquecendo-se que o próprio Marx elaborou suas teorias na perspectiva histórica, de transformação da realidade. (SPÓSITO, 2001. p. 101).

No campo das ciências, as modificações vivenciadas nesse período eram principalmente inerentes às novas tecnologias desenvolvidas, o que levou inúmeros pesquisadores a refletirem na busca de novas possiblidades teórico-metodológicas no século XX, a partir da década de 1970 na França e Brasil, tendo Yves Lacoste e Milton Santos como principais expoentes.

0 pensamento marxista chega à Geografia nos anos 1970, e em diferentes cantos do mundo. Nos anos 1950 um grupo de geógrafos de que fizeram parte Jean Tricart, Pierre George, René Guglielmo, Jean Dresch e Bernard Kayser e ainda podemos acrescentar Yves Lacoste, buscam criar na França uma Geografia fundada no materialismo histórico e dialético, que, entretanto, pouco avança nesse intento. Nos anos 1970, é a vez de um naipe de geógrafos, espalhados por vários países, como David Harvey e Edward Soja nos Estados Unidos, Milton Santos e Armando Corrêa da Silva no Brasil, Yves Lacoste na França e Massimo Quani na Itália, trazer de volta a relação entre marxismo e Geografia, fazendo dessa vez ir mais fundo o mergulho cruzado que ficara no meio do caminho com os geógrafos franceses. (MOREIRA, 2008, p. 40)

A Geografia Crítica “[...] baseou-se no materialismo histórico como doutrina e na dialética como método de investigação da realidade e se pautou, ora mais, ora menos explicitamente, pelo engajamento ideológico do pesquisador" (SPÓSITO, 2001. p. 101). É válido afirmar que a ação, a crítica e a autocrítica são aspectos fundamentais da prática intelectual dos profissionais que trabalham com a dialética.

Em termos teóricos, essa tendência caracteriza-se pela tentativa de desvendar conflitos de interesses, pela fundamentação teórica por meio da eleição das categorias de análise e na sua articulação com a realidade estudada, pelo questionamento da visão estática da realidade, por utilizar apontamentos para o caráter transformador dos fenômenos, relacionado à preocupação com a transformação da realidade estudada e da proposta teórica, procurando sempre o resgate da dimensão histórica dessa realidade, propondo-se as possibilidades de mudanças com base em uma postura marcadamente crítica. A Geografia Brasileira contemporânea, pela grande influência da Geografia Crítica, negligencia o mapa como instrumento da análise geográfica e como parte do discurso geográfico. Para entender melhor a atual situação do mapa na Geografia Brasileira, é necessário analisar seu papel nas correntes geográficas tradicional, pragmática e crítica (GIRARDI, 2008).

É relevante, neste momento, resgatar na abordagem de Seemann (2012) trechos da reflexão acercar da Geografia e da Cartografia Crítica no Brasil. Para o autor, "seria uma tentação estabelecer paralelos entre a Cartografia Crítica e a trajetória da Geografia Crítica no Brasil". Seria necessária uma análise dos pormenores do próprio movimento da Geografia Crítica a partir dos anos 60 para daí então ter um prognóstico da relação entre a práxis dos geógrafos ditos críticos e o uso dos mapas. Para o autor, tal trabalho ainda está por ser feito. Seemann (2012) comenta que nos anos 70 e 80 a Geografia Crítica brasileira possuía uma base teórica e filosófica consolidada para lutar contra as injustiças sociais, mas não era capaz de repensar e aproximar a o mapa dos estudos da Geografia Crítica. De igual modo, Kaecher (2004) verifica que na Geografia Escolar, bem como no livro didático de natureza crítica, o mapa não fazia parte do discurso ou da leitura do mundo por parte dos "militantes" desta corrente geográfica.

As influências que a Geografia Crítica teve sobre o não uso do mapa são perceptíveis não só nas pesquisas, mas também no ensino. Souza e Katura (2001) relatam que boa parte dos professores formados sob a 
égide da Geografia Crítica não utilizam o mapa em sala de aula, seja por não possuírem habilidade, ou até mesmo por não considerarem importante a espacialização das informações e/ou conteúdo das aulas.

Se por um lado a Geografia Neopositista se respaldou nos modelos matemáticos para a reflexão teórica e abandonou a ciência empírica, por outro Geografia Crítica continuou com forte base empírica, mesmo que tenha negligenciado a Cartografia como possibilidade da representação dos fenômenos geográficos. Essa corrente se materializa na segunda metade do século XX, a partir da década de 1980, na U.R.S.S e França, com o soviético Sotchava e os franceses Bertrand e Tricart. Nesse período, cresce o uso e aplicação da Cartografia Temática e do Geoprocessamento. Na Cartografia, vivencia-se o crescimento da Linha da Comunicação Cartográfica.

Claval (2006) coloca que a Nova Geografia Física põe, então, em termos adaptados às situações do mundo contemporâneo, com destaque para o problema das relações do homem e do ambiente. A análise das relações homem-meio ganha destaque com as técnicas de teledetecção; os sistemas de informação geográfica em parceria com os progressos da informática colocam a disposição dos apaixonados pela temática base de dados atualizados e de uma riqueza de detalhes que não fora possível outrora.

A Semiologia como Teoria Geral dos Signos também teve papel significativo no desenvolvimento teórico da Cartografia, dando origem à Semiologia Gráfica. Como linguagem cartográfica, fundamenta-se em uma ciência denominada semiótica, que tem por objeto de investigação todas as linguagens, em especial a dos signos. Signos são componentes linguísticos do sistema de informação cartográfica. Os trabalhos que mais se destacaram foram os do francês J. Bertin (1967), que sistematiza a linguagem gráfica como um sistema de símbolos gráficos com significado e significante. Os significantes são as variáveis visuais, utilizadas para transcrever as relações entre os dados. As variáveis visuais são: tamanho, valor, textura, cor, orientação e forma.

Figura 9 - Variáveis visuais criadas por Jaques Bertin.

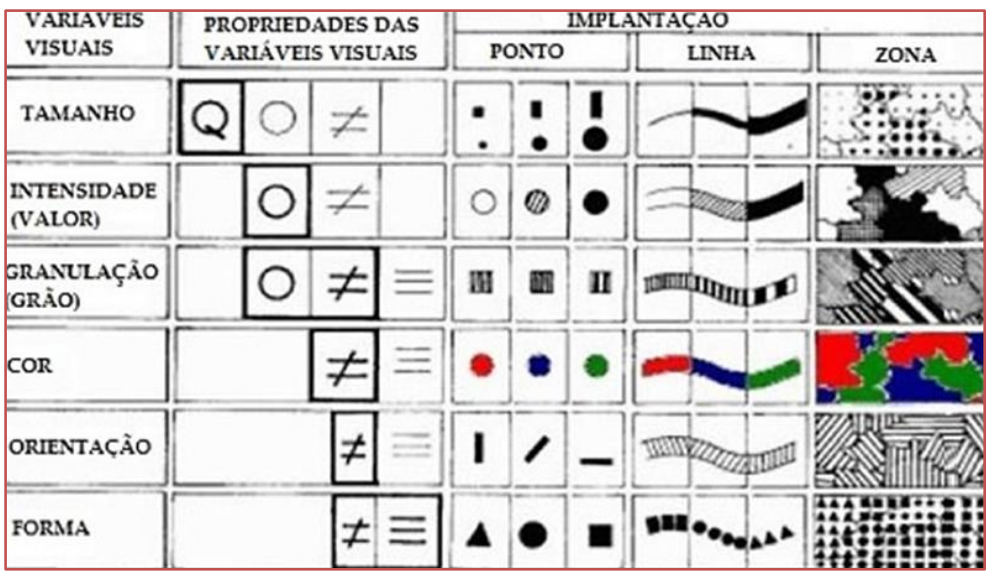

Fonte: Martinelli (2000)

Bertin foi o primeiro pesquisador a organizar um quadro de variáveis visuais, com as propriedades perceptivas da linguagem gráfica. Ele enfatizou a transcrição da linguagem escrita para a visual, considerando as relações apresentadas entre os dados. Assim, a sistematização de tais relações e sua representação gráfica são o ponto de partida na caracterização da linguagem gráfica. A Semiologia Gráfica começa a aparecer nas pesquisas do Brasil por volta dos anos de 1980, com a tradução de um artigo de Bertin e publicado na Revista Brasileira de Geografia (IBGE), no qual propõe uma orientação direcionada aos pesquisadores e usuários de mapas e gráficos. Os trabalhos de Marcelo Martinelli da USP tiveram grandes contribuições para a Geografia Brasileira.

O programa de Pós-Graduação em Geografia Humana da USP teve grande contribuição com as pesquisas de Martinelli com a linha de Cartografia Temática. Archela e Archela (2008) destacam três etapas no desenvolvimento das pesquisas em Semiologia Gráfica no Brasil. A primeira fase, de 1980 a 1984 , caracteriza-se pela introdução das bases desse enfoque, realizada através de artigos em periódicos de circulação nacional, em especial a Revista Brasileira de Geografia do IBGE. A segunda fase, de 1985 a 1989 , considerado pela autora como de grande produção científica, principalmente de artigos e trabalhos em 
eventos. A terceira fase de 1989 a 1995 apresentou muitas dissertações de mestrado baseados na semiologia gráfica como metodologia de ensino de Geografia.

Sposito (2001, p. 107) salienta que [...] nas últimas décadas do século XX, surgiram algumas novas orientações na produção do conhecimento geográfico. Muitas vezes, as orientações temáticas foram se transformando em paradigmas. Essa tendência, que podemos chamar de fenomenológica, tem sido utilizada com reconhecida consistência na Geografia Humanística para a interpretação das manifestações culturais de grupos específicos e do cotidiano urbano. No entanto, quando ela está na base teórica de instrumentos fundamentais para orientar o ensino de Geografia no Brasil, como os Parâmetros Curriculares Nacionais, que tem papel político na formação de professores dos ensinos fundamental e médio e dos futuros cidadãos, demonstra sua fragilidade na sua relação com a complexidade da realidade, principalmente por suas dificuldades em tratar a escala, na perspectiva epistemológica.

Moreira (2008) afirma que a fenomenologia é definida como a filosofia das essências e que sua origem moderna se deve a Edmund Husserl. A fenomenologia husserliana tem, de um lado, fortes vínculos com a filosofia de vida, de Wilhelm Dilthey, dela extraindo o conceito do real vivido e, de outro com a filosofia neokantiana, sua contemporânea, de onde extrai o conceito de essência. 0 autor evidencia ainda o percurso da fenomenologia dentro de algumas tendências da Geografia Contemporânea. Segundo ele, é a percepção ambiental a porta de entrada das correntes de Geografia no universo da fenomenologia husserliana, numa sequência em que, da Geografia da Percepção vai para a Geografia Humanística e desta para a Geografia Cultural, sendo que o fundamento fenomenológico viem a aparecer mais como um projeto que como um fato efetivado.

Moreira (2008) destaca que a fenomenologia huserliana chega á Geografia também nos anos 1970. Porém, não como uma fenomenologia das essências, mas como uma fenomenologia existencial, uma visão da fenomenologia mais afeiçoada à filosofia de Merleau-Ponty. Perfilam no seu terreno a Geografia da Percepção, a Geografia Humanística e a Geografia Cultural, além da Geografia Histórica, quatro versões derivadas das matrizes norte-americanas criadas por Sauer, aprofundadas por David Lowenthal e Anne Buttimer nos anos 1960 e dimensionadas por Yi-fu Tuan e Edward Relph, entre outros, nos anos 1970, com esses últimos chegando à matriz fenomenológica.

Holzer (2009) coloca que ainda na primeira metade da década de 1970, dois nomes foram importantes para a construção da identidade da Geografia Humanística, a saber: Tuan e Buttimer, ao introduzirem os conceitos de lugar e mundo vivido. No entanto, grande parte da literatura nacional destaca que a Geografia Humanística se consolida como corrente da Geografia a partir da década de 1980, na França e Estados Unidos, com Paul Claval e Yi-fu Tuan, respectivamente.

Na Cartografia tivemos o crescimento da linha da percepção e representação cognitiva do espaço. Essa corrente teórica da Cartografia Cognitiva teve no Brasil a contribuição da Psicologia Genética de Jean Piaget. Trabalhos como o de Lívia de Oliveira marcaram o início dos trabalhos desta linha (SILVA; CASSOL, 2010. p. 90). A Teoria da Cognição como método cartográfico envolve operações mentais lógicas como a comparação, análise, síntese, abstração, generalização e modelização cartográfica. Segundo Archela e Archela (2002), nessa corrente o mapa é considerado como uma variável de informações, dependendo das características do usuário.

Essa corrente foi desenvolvida a partir da Psicologia e trouxe grandes avanços para a Cartografia, tanto no processo de mapeamento, em que o cartógrafo passou a ter uma preocupação maior com as características do usuário, como no processo de leitura, no qual o mapa passou a ser um instrumento para a aquisição de novos conhecimentos sobre a realidade representada. Dentre as contribuições da linha da percepção e representação cognitiva do espaço destaca-se a Cartografia Escolar e a criação dos mapas mentais e da alfabetização cartográfica.

No entanto, a partir dos anos 80 é possível perceber uma aproximação da Geografia com a Cartografia a partir das teorias sociais críticas. Nesse momento, os estudos ligados à linha da Cartografia Escolar ganham destaque a partir do trabalho de Oliveira (1978), com trabalhos desenvolvidos principalmente ligados à epistemologia genética de Piaget e à percepção de Yi-Fu Tuan.

No nível teórico, as histórias de vida e o discurso próprio, com a incorporação da informação a partir da postura do investigador, é a base para se utilizar as técnicas qualitativas, que se realizam por meio da pesquisa participante, de entrevistas, de relatos de vivências, da observação e de práticas alternativas e inovadoras. Em termos epistemológicos, essa tendência, que pode ser também considerada um 
terceiro grande paradigma da ciência ocidental, pauta-se pela postura crítica de autores da fenomenologia, com interesse em desvendar as características do objeto. (SPOSIT0, 2001.p. 105)

Acredita-se que seja insuficiente em poucas linhas traçar o perfil da Geografia a partir de suas correntes de pensamento e estabelecer uma relação entre a produção do conhecimento geográfico e a Cartografia. Nas investigações teóricas realizadas para produção deste trabalho fica evidente que nas correntes apoiadas no Positivismo, embora demonstrem uma preocupação na caracterização do espaço geográfico, é pouco expressiva a ênfase dada à Cartografia, tanto nas obras clássicas quanto nas obras mais recentes que fazem referências as características destas correntes.

\subsection{ESTADO DA ARTE E PERSPECTIVAS DO ENSINO DE GEOGRAFIA NO BRASIL}

Inicia-se esta parte com a apresentação dos resultados de quatro grandes levantamentos realizados com o intuito de apresentar o estado da arte dos estudos sobre ensino de Geografia no Brasil. Inicialmente, temse os dados da tese de doutorado de Pinheiro (2005), publicado em forma de livro, seguido pelo trabalho de Cavalcanti (2010), Buitoni (2014) e Callai et. al. (2016).

O primeiro trabalho representa um levantamento de dissertações e teses representando a produção do conhecimento especialmente da segunda metade do século XX, no qual o autor já aponta um crescimento significativo da temática ligada à representação espacial. Os trabalhos pioneiros nessa linha aparecem a partir do final dos anos 70 e apresentam um crescimento até o início do século XXI.

Quadro 11 - Focos Temáticos Identificados por Pinheiro (2005)

\begin{tabular}{|c|l|}
\hline Ordem & \multicolumn{1}{|c|}{ Focos Temáticos } \\
\hline 1 & Prática Docente e Educativa \\
\hline 2 & Representações Espaciais \\
\hline 3 & Educação Ambiental \\
\hline 4 & Formação de Professores \\
\hline 5 & Características dos Alunos \\
\hline 6 & Livro Didático \\
\hline 7 & Currículo e Programas \\
\hline 8 & Formação de Conceitos \\
\hline 9 & Conteúdo-Método \\
\hline 10 & História da Geografia \\
\hline
\end{tabular}

Fonte: Pinheiro (2005). Organização dos autores.

No segundo caso, Cavalcanti (2010) apresenta uma diversidade de focos temáticos presentes nas pesquisas sobre o ensino de Geografia, com destaque para o trabalho com os conceitos geográficos e a utilização da linguagem cartográfica. Um detalhe a considerar nesse segundo caso é a presença da grande quantidade de trabalhos/temáticas abordando o ensino de Geografia nos anos iniciais do ensino fundamental. Chama-se atenção para esse detalhe pelo fato de que a atuação na docência nos anos iniciais cabe ao pedagogo e não ao geógrafo licenciado. No entanto, a autora chama atenção para um detalhe presenta na proposta curricular para o ensino fundamental, organizada em ciclos, na qual a Cartografia aparece como sugestão de eixo temático no terceiro ciclo (6ํㅜ e $7^{\circ}$ ano). 
Quadro 12 - Focos temáticos identificados por Cavalcanti (2010)

\begin{tabular}{|c|l|} 
Ordem & \multicolumn{1}{c|}{ Focos Temáticos } \\
\hline 1 & O lugar como referência no tratamento dos conteúdos geográficos \\
\hline 2 & Formação de conceitos instrumentalizados pelo pensamento espacial \\
\hline 3 & Utilização da Linguagem Gráfica e Cartográfica \\
\hline 4 & $\begin{array}{l}\text { Utilização de linguagens alternativas (literatura, música, cinema, jogos e outros } \\
\text { produtos digitais) }\end{array}$ \\
\hline 5 & Tratamento das temáticas físico-ambientais \\
\hline
\end{tabular}

Organização dos autores.

O terceiro trabalho traz um levantamento das temáticas presentes nos eventos da Associação dos Geógrafos Brasileiros (AGB), considerando apenas os Encontros Nacionais de Geógrafos entre 2008 e 2012. No entanto, vale ressaltar que além desse são realizados com a mesma periodicidade os Encontros Nacionais de Estudantes de Geografia (ENEG), bem como o Congresso Brasileiro de Geógrafos, esse último realizado a cada dez anos.

Tabela 7 - Temáticas presentes nos Eventos da AGB

\begin{tabular}{|l|c|c|c|}
\hline \multicolumn{1}{|c|}{ TEMÁTICAS } & 27 & 42 & 56 \\
\hline Cartografia Escolar & 26 & 38 & 24 \\
\hline Reflexões sobre Geografia Escolar & 25 & 63 & 56 \\
\hline Educação Ambiental & 23 & 47 & 50 \\
\hline Formação de Professores & & & 5012 \\
\hline
\end{tabular}

Fonte: Buitoni 2014. Organização dos autores.

Callai et. al. (2016) apontam uma evolução quantitativa e qualitativa dos trabalhos apresentados no evento da Associação Nacional de Pós-Graduação e Pesquisa em Geografia, ressaltando que as pesquisas destacam maior rigor teórico e metodológico, clareza dos objetivos, bem como maior cuidado com a linguagem acadêmica. Os autores agrupam os trabalhos em quatro grupos temáticos e, dentro de cada um dos quatro grupos, identificam categorias predominantes, como se observa no quadro abaixo.

Quadro 13 - Temáticas a presentadas no XI ENAPEGE em 2015

\begin{tabular}{|c|l|l|c|}
\multicolumn{1}{|c|}{ Ordem } & \multicolumn{1}{|c|}{ Trupos temáticos } & \multicolumn{1}{c|}{ Categorias } \\
\hline 1 & Metodologia de Ensino de Geografia & $\begin{array}{l}\text { Ensino por } \\
\text { Conceitos }\end{array}$ & 18 \\
\hline 2 & Ensino e Aprendizagem em Geografia & $\begin{array}{l}\text { Livro didático e } \\
\text { Conteúdo }\end{array}$ & 10 \\
\hline 3 & Currículo no Ensino da Geografia & Formação Inicial & 06 \\
\hline 4 & Formação de Professores de Geografia & & 48 \\
\hline
\end{tabular}


Os autores destacam um aprofundamento teórico das pesquisas em dois aspectos: primeiro, para as análises e busca de entendimento do fenômeno da educação geográfica. Segundo uma produção significativa de dados empíricos que sustentam e contribuem para a compreensão do fenômeno. Apontam ainda para algumas temáticas emergentes que estão sempre presentes nos anis dos eventos ligados ao ensino como: a Cartografia Escolar/Cartografia para crianças e escolares, métodos e metodologias de ensino, políticas educacionais, currículo escolar, avaliação da aprendizagem, formação de professores, aprendizagem escolar, construção de conhecimentos, conceitos geográficos.

Com relação às temáticas apresentadas, destaca-se uma delas, que é a Cartografia no ensino de Geografia. A Cartografia Escolar tem sido um tema bastante presente em eventos acadêmicos no Brasil nas últimas duas décadas (trabalhos da AGB; Cartografia para Escolares; e PINHEIRO, 2005). A Cartografia é trabalhada e entendida hoje não somente como um conteúdo, mas como uma linguagem capaz de facilitar a forma de leitura e compreensão do mundo. Relacionadas à Cartografia escolar os autores apresentam algumas vertentes presentes nos anais do evento, como: a construção de conceitos cartográficos em alunos do ensino fundamental e a importância do raciocínio espacial para crianças em idade escolar.

Para Callai (2009), o processo de explicação do mundo através de uma análise geográfica exige o desenvolvimento de um olhar espacial, de um raciocínio espacial ou geográfico para daí então fazer a interpretação da realidade e da sociedade expressa no tempo. Isso se faz no decorrer da formação inicial e prossegue na trajetória da formação continuada e no mundo do trabalho. Portanto, ao se falar de formação de professor deve-se levar em consideração no mínimo três aspectos que são: a formação inicial, a formação continuada e o mundo do trabalho. Para muitos, a formação inicial e continuada é vista e tratada como sinônimo, porém há de se considerar que a formação continuada acontece enquanto os sujeitos encontram-se submergidos no mundo do trabalho e que nem sempre é uma garantia por parte do poder público, seja qual nível de governo for, salvo quando o próprio professor resolve fazer um investimento pessoal em sua formação continuada.

Há de se reconhecer que no atual estágio em que se encontra a sociedade, mudaram as características das relações sociais, assim como alteraram também as noções de espaço e tempo. Hoje, grande parte dos alunos em idade escolar são filhos de pais separados, os professores são pais/mães, têm vida social/cultural, exercem funções domésticas. A escola assume um novo papel de disseminadora de cultura para abrigo de jovens sem perspectivas de vida diante de um currículo que não dialoga com suas realidades. Diante disso, o que fazer para que a Geografia Escolar contribua de fato com a ressignificação da escola e do ensino de Geografia?

Atualmente, tem-se a sensação de que a formação inicial de professores no Brasil deixa muito a desejar. Para os estudantes da educação básica, a Geografia não tem significado algum para sua vida cotidiana. Muitas vezes até tem, mas não é feita uma reflexão usando o olhar espacial e o raciocínio geográfico tão necessário. Os estudantes da universidade em processo de formação veem-se diante de um labirinto de especialidades compartimentadas através de grupos de pesquisas, laboratórios que, na maioria das vezes, acarreta em uma escolha prematura por uma área específica dentro da Geografia, seja por necessidade de uma bolsa de iniciação científica, extensão ou ensino, seja pela falta de um espaço acadêmico que tenha de fato a real preocupação com a formação plena do acadêmico.

O exercício do magistério é atomizado na Geografia universitária. E necessariamente integrado na Geografia escolar. Na Geografia universitária o ensino é exercício de uma diversidade de especialidades tanto na Geografia física, quanto na humana, já na escola é exercido por um único professor. Isso cria uma dinâmica de concepção e de formulação prática de Geografia e de vida inteiramente distinta. (MOREIRA, 2014. p. 153)

Essa realidade acontece não só nos grandes centros, mas já chega aos pequenos centros, na maioria das vezes transplantada por professores recém-formados na pós-graduação que acabam reproduzindo tais práticas onde iniciam sua atuação docente. Vale lembrar do que aponta Moreira (2014), que defende que, na educação básica, a Geografia é um componente curricular sob a responsabilidade de um único professor. Na academia existe o fatiamento em áreas e subáreas. Cada um é especialista em uma parte da Geografia e cabe ao futuro professor em processo de formação fazer essa conexão, que nem sempre acontece no chão da sala de aula.

Cavalcanti (1998) relembra que a Geografia desenvolveu uma linguagem, um corpo conceitual que acabou por constituir-se numa linguagem geográfica. Seja na Geografia Acadêmica, seja na Geografia Escolar, essa 
linguagem está permeada por conceitos que, para a autora, são requisitos básicos para se fazer uma leitura geográfica do mundo.

Callai (2009) faz um questionamento importante para a reflexão que se faz neste momento: qual a dificuldade de encarar essa realidade e buscar a compreensão de como tornar significativo este ensino? A resposta para tal questionamento não é tão fácil, pois depende de uma infinidade de variáveis, atores e decisões a serem tomadas. Acredita-se que as mudanças anunciadas no sistema de ensino nacional sejam as já aprovadas e publicadas, sejam as em processo de reformulação tendem a causar um certo mal-estar principalmente no espaço acadêmico, não por ser um espaço que privilegia tais discussões e sim por vaidades acadêmicas. Fala-se de vaidades acadêmicas no sentido de que as elaborações dessas reformulações são feitas por universidades ou por grupos de professores universitários e sempre fica claro nos documentos oficiais referentes ao ensino a identidade de quem os elabora; foi assim com os PCN, BNCC do ensino fundamental e não é de se esperar muitas mudanças na BNCC do ensino médio.

Um aspecto adicional que se põe hoje tanto para a Geografia acadêmica quanto para a Geografia escolar é o processo de reforma pela qual estão passando mesmo que lentamente, não se sabe ao certo se pelo agravamento da crise política, ou se é de fato intencional esta lentidão. (MOREIRA, 2014. p. 154)

No entanto, para isso, o professor necessita ter construído solidamente seus referenciais teóricos que lhe permitam sustentar debates, apresentar proposições e soluções criativas nos processos de conhecimento, de planejamento e de gestão pedagógica dos conteúdos de ensino da Geografia Escolar. É no chão da sala de aula, ou seja, no mundo do trabalho que o professor precisa tomar certas decisões do que ensinar e como ensinar de forma a atender as necessidades dos sujeitos da aprendizagem. Para isso, é importante que o professor conheça tanto a realidade do mundo empírico quanto as proposições teóricas que lhe habilitam para tal. Daí a necessidade de voltar a mencionar o binômio formação inicial e continuada. Sabese que a formação inicial não dá conta de prepará-lo cem por cento para exercer a docência, daí a necessidade de políticas públicas que vissem à formação continuada em exercício e contribua de forma efetiva para melhorias da prática docente.

É a partir da Nova Geografia que a Cartografia começa a fazer parte dos estudos geográficos. Talvez devido aos investimentos sucessivos feitos pelas potências do período, a saber, U.R.S.S e Estados Unidos, nesse período foram lançados vários satélites e a tecnologia espacial ganha destaque. No entanto, é a partir doa anos de 1970 que essas tecnologias chegam de fato, através dos SIG, do Sensoriamento Remoto e Cartografia Digital. 0 uso de imagens de satélites, GPS, fotografias aéreas e mais recentemente dos VANT tem contribuído de forma gigantesca para os estudos do espaço geográfico. Mas, vale considerar que essas tecnologias não resolvem o problema maior na construção de conhecimentos significativos, pois são os métodos que vão nortear a produção de conhecimento nos diversos campos da Geografia.

0 mapa não é apenas uma descrição da realidade, mas, em sentido literal, representa um retrato de uma realidade. Os mapas que são elaborados por intermédio dos vários softwares SIG são propositalmente seletivos, pois são representados no mapa apenas os aspectos que interessam, sendo desprezadas todas as divergências entre os aspectos representados. Um dado importante a ser considerado é que todas as correntes teóricas da Cartografia desenvolvidas a partir da década de 1960, independente da terminologia recebida, têm em comum o sistema de análise, a saber: a realidade, o criador de mapas, o usuário de mapas e imagem da realidade expressa através do mapa. Assim, varia apenas o veículo de informação através da modelização, da semiologia ou a cognição, o que torna a Cartografia uma linguagem fundamental para o processo de comunicação na contemporaneidade.

Portanto, a Cartografia é uma dentre muitas linguagens que os seres humanos utilizam para facilitar o processo de comunicação entre seus pares. A palavra "linguagem" pode ser definida como um conjunto ou sistema de signos usado para expressar ideias e sentimentos como a fala, a escrita ou a mímica. Um signo, por sua vez, é composto de dois componentes: uma palavra, um desenho ou outra expressão simbólica (chamado de significante), que é usado para descrever ou apresentar um conceito, um objeto ou um processo chamado de significado (SANTAELLA, 2012). 


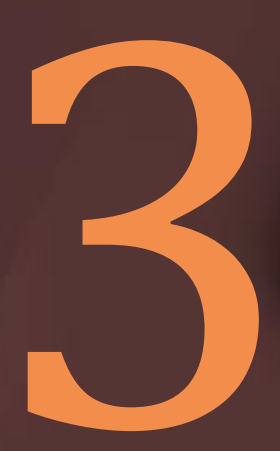

A Linguagem Cartográfica no currículo de Geografia 
Existe atualmente uma grande quantidade de estudos referentes à Cartografia Escolar no Brasil, que abordam os diferentes níveis de ensino e vão desde as séries iniciais do ensino fundamental até o ensino superior. Ao verificar tais estudos, é possível identificar ainda algumas lacunas no conhecimento existente acerca da Cartografia Escolar e seus reflexos no ensino da Geografia. Pode-se citar dentre elas: poucos trabalhos que abordam o processo de ensino da Geografia, a grande maioria dos estudos dão ênfase à aprendizagem em Geografia, em especial focam o uso da linguagem cartográfica nas séries iniciais como princípio da alfabetização cartográfica. São poucos os trabalhos referentes ao ensino que utilizam a linguagem cartográfica no ensino superior e no ensino fundamental do 6ํㅜ ao 9o ano.

As abordagens teóricas que sustentam a cientificidades dos referidos estudos são pouco incipientes também. Em geral, os trabalhos referem-se a experiências isoladas, aplicação de metodologias, atividades feitas em sala com alunos, uso de recursos didáticos associados a conteúdos geográficos. Poucos são os trabalhos que tentam revelar os saberes que fundamentam o trabalho do professor de Geografia concernente ao uso da Cartografia enquanto linguagem nos processos pedagógicos em sala de aula.

Com relação aos trabalhos desenvolvidos no Brasil a partir do final da década de 1970, é possível apresentar um desenho das principais teorias que têm norteado os trabalhos com a linguagem cartográfica. Inicialmente e em grande maioria temos os trabalhos que utilizaram e ainda utilizam a Epistemologia Genética de Jean Piaget como modelo teórico de análise; são trabalhos que, em geral, enfocam a aprendizagem dos conceitos e noções espaciais e focam as séries iniciais do ensino fundamental. Temos os trabalhos orientados pela Semiologia de Jaques Bertin, em especial os trabalhos com atlas escolares, gráficos e Cartografia Temática. É possível também identificar o uso da Teoria Simbólica (Dialogismo) de Mikhail Bakhtin e mais recente os trabalhos orientados pela Teoria HistóricoCultural de Vygotsky, Teoria da Complexidade de Edgar Morin e Teoria do Ensino Desenvolvimental de Davidov.

Feita essa exposição inicial do arsenal teórico que tem norteado as pesquisas na linha da Cartografia Escolar, cabem alguns questionamentos para pensar o papel desempenhado por esta linha de pesquisa no ensino da Geografia Escolar. O primeiro questionamento é qual o lugar da linguagem cartográfica no currículo da Geografia para a educação básica? Segundo, até que ponto as produções na linha da Cartografia Escolar têm contribuído para melhorias no ensino de Geografia?

Dessa forma, o capítulo está assim estruturado: apresentam-se inicialmente os primeiros trabalhos desenvolvidos nas décadas de 1970 e 1980, em seguida apresentam-se os demais trabalhos desenvolvidos mais recentemente, agrupados em eixos temáticos, as teorias que nortearam os trabalhos desenvolvidos e, por fim, as perspectivas dessa linha no mundo contemporâneo.

\subsection{CARTOGRAFIA ESCOLAR NO BRASIL}

A Cartografia Escolar encontra-se inserida na Teoria Cognitiva como método cartográfico, pois envolve operações mentais lógicas como a comparação, análise, síntese, abstração, generalização e modelização cartográfica (ARCHELA; ARCHELA, 2002). Nessa corrente de pesquisa da Cartografia Moderna, o mapa é considerado como uma fonte variável de informações, dependendo das características do usuário. Desenvolvida a partir da Psicologia, trouxe grandes avanços para a Cartografia, tanto no processo de mapeamento, em que o cartógrafo passou a ter uma preocupação maior com as características do usuário, como no processo de leitura e interpretação, no qual o mapa passou a ser um instrumento para aquisição de novos conhecimentos sobre a realidade representada. Entre as principais contribuições estão os mapas mentais e a alfabetização cartográfica.

No Brasil, o primeiro trabalho na linha da cognição cartográfica foi desenvolvido por Lívia de Oliveira (1978), na obra Estudo metodológico e cognitivo do mapa, baseado na Psicologia Genética de Piaget. Para a autora, havia naquele momento a necessidade do estabelecimento de uma metodologia que ajudasse o professor a ensinar Geografia com o uso do mapa. Ela também indicou a urgência de desenvolver uma Cartografia para crianças, pois, em geral, usam-se mapas feitos por adultos para ensinar conteúdos geográficos a crianças.

Esse trabalho, considerado como um impulso inicial na direção do ensino e aprendizagem do mapa no Brasil, deu origem a outras pesquisas em Cartografia e cognição, como também em semiologia gráfica e comunicação cartográfica, como as obras de Cartografia para o ensino fundamental. Podem-se destacar os trabalhos de Simielli (1993) e Almeida e Passini (1989). Apoiada nessa mesma linha teórica ligada à cognição na Cartografia, Nogueira (1994) apresentou reflexões e questionamentos quanto aos mapas mentais, vistos como representações mentais que cada indivíduo possui dos espaços que conhece. Com 
base em vários autores, argumentou que os mapas mentais podem ser utilizados como material didático pelos professores, para estudar o espaço e introduzir ao mesmo tempo o ensino elementar das representações cartográficas.

Outros trabalhos de renomados pesquisadores do país merecem destaque. Ao selecionar apenas alguns trabalhos, a intensão não é colocá-los como mais importantes, e sim ser fiel ao procedimento de investigação (pesquisa bibliográfica e documental) proposto neste trabalho. Iniciamos com a obra de Almeida (2007), Cartografia Escolar, no qual a autora reúne os principais trabalhos dessa linha. Os trabalhos estão organizados em torno de duas correntes teóricas sendo a primeira a Epistemologia Genética de Piaget com os seguintes trabalhos: Oliveira (1978), Paganelli (1987), Simielli (1987), Almeida (1993), Almeida (1994) e Passinni (1996). A segunda corrente é a Semiologia Gráfica de Bertin, com os trabalhos de Le Sann (1983) e Martinelli (1999).

Dito isso, a intenção agora é mostrar como o trabalho desses pesquisadores pioneiros influenciaram novas pesquisas e novas abordagens sob a ótica de teorias até então ausentes nos estudos da Cartografia Escolar no país. As obras de Souza e Katuta (2001) e Almeida e Almeida (2014) são de grande relevância para o entendimento do desenvolvimento e evolução dessa linha de pesquisa e para ajudar a compreender melhor a trajetória dessa linha de pesquisa.

\subsection{OS ESTUDOS E AVANÇOS DA CARTOGRAFIA ESCOLAR NO BRASIL}

A partir do final dos anos 70 e início da década de 80, surgem no Brasil pesquisas em que a Cartografia Escolar vem se estabelecendo como um conhecimento construído nas interfaces entre Cartografia, Educação e Geografia (ALMEIDA, 2010). Mais recentemente, Francischett (2001) defende sua tese de doutorado A Cartografia no ensino de Geografia: a aprendizagem mediada, na qual desenvolve o trabalho objetivando construir uma proposta metodológica de ensino-aprendizagem da Geocartografia no ensino superior. Em uma abordagem interdisciplinar, verificou-se a importância das representações cartográficas, especificamente da maquete, para o estudo do espaço geográfico.

Girardi (2008), em sua tese de doutorado Proposição teórico-metodológica de uma Cartografia geográfica crítica e sua aplicação no desenvolvimento do atlas da questão agrária brasileira, expõe uma proposta teórico-metodológica de uma Cartografia geográfica crítica cujo objetivo principal é contribuir para o desenvolvimento da Geografia Crítica com a reparação da negligência dessa corrente em relação ao mapa, o que implica valorizar o uso do mapa e do mapeamento.

Richter (2010), em sua tese de doutorado Raciocínio geográfico e mapas mentais: a leitura espacial do cotidiano por alunos do ensino médio, salienta que no desenvolvimento do raciocínio geográfico as atividades didáticas de Geografia utilizam diferentes linguagens que buscam ampliar as leituras e as análises dos alunos em relação aos elementos que compõem o espaço. Entre as linguagens, a cartográfica contribui significativamente para o processo de ensino-aprendizagem da Geografia, pois se ocupa da representação do espaço. Argumenta também que no processo desconstrução da representação cartográfica, o mapa mental pode ser validado como um recurso que permite a inserção de leituras e interpretações espaciais (raciocínio geográfico) que o aluno produz em relação ao cotidiano.

No livro Cartografia Escolar, Almeida (2007) reúne quatro autoras consagradas no âmbito educacional brasileiro, que condensam alguns de seus trabalhos mais importantes, tanto pela expressividade quanto por serem, atualmente, os referenciais teóricos mais utilizados. Oliveira (1978) apresenta, neste livro, um dos estudos pioneiros no país, ao condensar sua tese de livre-docência intitulada Estudo metodológico e cognitivo do mapa, enfatizando a necessidade de o aluno estar preparado para entender mapas e da elaboração de uma Cartografia Infantil como uma metodologia para ensino do mapa. Paganelli (1982) sintetiza sua dissertação de mestrado para a construção do espaço geográfico na criança analisando o papel da percepção e da locomoção no espaço geográfico por crianças em diferentes faixas de idade. Simielli (1986) expõe sua tese de doutorado 0 mapa como meio de comunicação: implicações no ensino de Geografia no 1ำ Grau, avaliando a eficácia do mapa como instrumento transmissor de informação e como meio de comunicação. Almeida (1994), organizadora do livro, apresenta parte de sua tese de doutorado intitulada Uma proposta metodológica para a compreensão de mapas geográficos, e traz uma orientação metodológica para o ensino de conceitos cartográficos fundamentada na representação espacial pela criança.

Autora também do livro Do desenho ao mapa: iniciação cartográfica na escola, co-autora de Espaço geográfico: ensino e representação e organizadora do livro Novos rumos da Cartografia Escolar: currículo, linguagem e tecnologia. 
Rosangela Doin de Almeida é conhecida pelas publicações sobre a linguagem cartográfica em contexto escolar tanto em nível nacional quanto em nível internacional. Seus trabalhos são de grande importância, tanto pela representatividade como por suscitarem novas pesquisas na esfera acadêmica e profissional. A UNESP de Rio Claro mais uma vez destaca-se na produção intelectual, como visto em tópico anterior neste trabalho. Durante a Geografia Teorética essa IES foi destaque com os trabalhos de Christofoletti e posteriormente com os trabalhos de Lívia de Oliveira.

Atualmente, um grupo de pesquisadores liderados por Rosangela Doin de Almeida e Maria Isabel Castreghini de Freitas tem apresentado uma produção significativa de trabalhos ligados à Cartografia Escolar, com destaque para a publicação da editora Springer da obra Maps for the Future: children, education and internet, organizada pelos húngaros Zentai e Nunez (2012), com nove capítulos de autores brasileiros. Além das autoras citadas, alguns de seus ex-orientandos e Marcelo Martinelli compõem a equipe de brasileiros com trabalhos publicados na referida obra.

Muitos artigos também enfocam a importância da linguagem cartográfica aplicada ao ensino de Geografia. Alguns bem recentes são bastante representativos para a proposta deste texto. Santos (2007), em artigo intitulado Ensino de Geografia nos anos iniciais: leitura de mundo através de conceitos e mapas, publicado na revista Poiésis Pedagógica, põe em questão a relevância da Cartografia nos anos iniciais, possibilitando às crianças uma variedade de representações para o estudo dos lugares e do mundo. Girardi (2009), em artigo publicado na revista Pro-Posições, com o título Mapas desejantes: uma agenda para a Cartografia Geográfica, discute como imagens cartográficas difundidas na vida social produzem diversos ambientes. A autora ainda propõe reflexões sobre a utilização de mapas em dimensões diversas da vida em sociedade.

Richter, Marin e Decanini (2010), em artigo intitulado Ensino de Geografia, espaço e linguagem cartográfica, publicado na revista Mercator, consideram que a análise espacial necessita da inserção de práticas pedagógicas que articulem os conceitos com a linguagem cartográfica, e que o mapa mental é uma proposta muito pertinente para desenvolver o raciocínio geográfico. Silva e Cassol (2010), no artigo Evolução da Cartografia no ensino da Geografia: um olhar sobre os caminhos percorridos, tratam da elucidação teórica da evolução da Cartografia na perspectiva da Geografia Escolar. Em suas análises, constataram que a representação dos elementos espaciais contribuiu, desde sempre, para que os alunos aprendam a analisar o cotidiano geograficamente e a construir uma consciência espacial dos fatos e fenômenos socialmente produzidos ou grupos envolvidos no processo de ensino e aprendizagem.

Na fase germinativa da Cartografia Escolar, sob a luz da Psicologia Genética e da Semiologia, a primeira se desenvolve inicialmente na UNESP de Rio Claro e a segunda na USP. A partir do final do século XX e início do XXI outros centros de pesquisas começam a fazer parte deste movimento e novas temáticas surgem, novas teorias são inseridas no senário da pesquisa acadêmica. Souza e Katura (2001) apresentam o estado da arte da Cartografia Geográfica no Brasil, agrupado em três grandes eixos. A ordem dos eixos apresentada no texto não obedece a ordem que os autores apresentam na obra. Optou-se por esta ordem por uma questão didática e cronológica.

Quadro 14 - Estado da arte da Cartografia no Brasil

Técnicas de comunicação cartográfica

Teoria da

aprendizagem

Metodologia

de ensino
Neste eixo se enquadram os trabalhos produzidos desde a década de 60 até os dias atuais. Em geral, estes trabalhos foram guiados pela Teoria da Semiologia de Jaques Bertin. No Brasil, os autores destacam os trabalhos de Marcelo Martinelli, da USP, com a linha da Cartografia Temática.

Este eixo tem início com o trabalho da Lívia de Oliveira, no final da década de 70 e guiado pela Epistemologia Genética de Jean Piaget. Outros trabalhos foram desenvolvidos a partir das contribuições da Teoria Histórico-Cultural de Vygotsky.

Neste eixo se enquadram os trabalhos que se valem das pesquisas ligadas a duas linhas acima (Epistemologia Genética e Teoria Histórico-Cultural) que servem como propostas de orientação didática a fim de contribuir com o ensino da Geografia Escolar.
Trabalhos pioneiros segundo os autores foram: Teixeira Neto (1982), Le Sann (1983), Martinelli (1984), Simielli (1986).

Destaque para os trabalhos de: Oliveira (1978; 1985), Paganelli (1987), Almeida e Passini (1989), Katuta (1992, 1993), Passini (1994; 1997).

Os autores destacam os seguintes trabalhos: Simielli (1986), Almeida (1994), Passini (1997). 
No primeiro eixo, referente as técnicas de comunicação cartográfica, os autores destacam que o objetivo é discutir duas questões fundamentais que são: a Teoria da Comunicação (Kolacny) e as diferentes técnicas de representação cartográfica (Bertin). Já no segundo eixo os autores apontam as teorias que auxiliam no processo de aprendizagem dos conceitos e conteúdos geográficos e cartográficos. Vale ressaltar que um dos conceitos cartográficos mais estudados nesse eixo foi o de alfabetização cartográfica. Para Silva e Cassol (2010), o processo de alfabetização cartográfica deve ser iniciado a partir da realidade do aluno por meio do emprego da percepção, estando o professor atento às capacidades de cada faixa etária dos estudantes e suas experiências pessoais.

Por fim, o terceiro eixo refere-se a metodologias de ensino, e procura discutir problemas sobre as dificuldades de leitura de mapas ou elaborar técnicas de aprendizagem que facilitem a construção de conceitos geográficos e cartográficos junto a alunos que vão desde os anos iniciais até o ensino médio, com o intuito de que esses alunos se tornem leitores de mapas.

Feita essa abordagem inicial do estado da arte da pesquisa em Cartografia, com base na obra de Souza e Katura (2001), segue-se a abordagem do desenvolvimento da pesquisa em Cartografia Escolar especificamente. Mediante um levantamento dos trabalhos desenvolvidos no Brasil, procurou-se reunir as principais teorias que têm orientado a produção acadêmica nas universidades, seja por meio de grupos de pesquisa ou de programas de pós-graduação. A fonte básica de coleta de dados foi o banco de teses e dissertações da CAPES.

No Quadro 15 estão reunidas as principais teorias, seus respectivos autores e seguidas de alguns trabalhos desenvolvidos por pesquisadores. Ressalta-se que o fato de ser citado apenas um trabalho por corrente teórica, não significa que outros trabalhos existentes, porém não citados neste trabalho, não tenham importância para a Cartografia Escolar.

Quadro 15 - Teorias que Nortearam as Pesquisas na Cartografia Escolar no Brasil

\begin{tabular}{|l|l|l|}
\multicolumn{2}{|c|}{ TEORIA } & \multicolumn{1}{c|}{ AUTOR } \\
\hline Psicologia Genética & Jean Piaget & Oliveira (1978) \\
\hline Semiologia Gráfica & Jaques Bertin & Martinelli (1984) \\
\hline Comunicação Cartográfica & Kolacny & Simielli (1986) \\
\hline Linguagem Semiótica & Mikail Bakhtin & Teixeira (2001) \\
\hline Teoria Histórico Cultural & Vygotsky & Richter (2010) \\
\hline Teoria da Complexidade & Edgar Morin & Silva (2013) \\
\hline Aprendizagem Desenvolvimental & Davidov & Moraes (2014) \\
\hline
\end{tabular}

Organização dos autores.

Vale ressaltar ainda que as teorias citadas no quadro acima não representam a totalidade das teorias que têm auxiliado a produção acadêmica no Brasil. A intenção não é esgotar o tema, e sim trazer uma contribuição para a compreensão do crescimento e da importância dessa linha de pesquisa para a Geografia Brasileira. Diante do exposto, cabe agora pensar nos desafios e perspectivas da pesquisa em Cartografia Escolar para as próximas décadas.

\subsection{PERSPECTIVAS DA CARTOGRAFIA ESCOLAR NO BRASIL}

Na tentativa de conhecer como andam as pesquisas na linha da Cartografia Escolar, fez-se uma busca no diretório de grupos de pesquisa do CNPq e foram identificados 22 grupos de pesquisa com linhas de pesquisa ligadas à Cartografia Escolar e ao ensino de Geografia (ver Quadro 16). 
Quadro 16 - Distribuição dos grupos de pesquisa com a linha de Cartografia Escolar no Brasil.

\begin{tabular}{|c|c|c|}
\hline REGIÕES & GRUP & IES \\
\hline Norte & 1 & UEPA \\
\hline Nordeste & 8 & UFAL, UNEAL, UEMA, UESPI, UVA, UFBA, IFBAIANO, UERN \\
\hline Centro Oeste & 1 & UFG \\
\hline Sudeste & 7 & UFU, UFSJ, USP, UFRRJ, UNESP (PP), UNESP (RC), UFSCAR \\
\hline Sul & 5 & UFFS, UEM, UEL, UFSM, UFSC \\
\hline Total & & 22 \\
\hline
\end{tabular}

Fonte: Diretório de Grupos de Pesquisa do CNPq (2017). Acesso em 16.11.2017. Organização dos autores.

Observa-se no quadro acima que as regiões Nordeste e Sudeste concentram a maior quantidade de grupos de pesquisa que têm uma linha de pesquisa ligada à Cartografia Escolar. No entanto, vale ressaltar que embora a região Nordeste concentre um número maior de grupos de pesquisa em relação à região Sudeste estes grupos não estão ligados a programas de pós-graduação stricto sensu.

Com a intenção de mostrar as novas perspectivas da Cartografia Escolar no Brasil, Almeida e Almeida (2014), através da análise dos anais do Colóquio de Cartografia para Escolares apontam algumas áreas de ação sendo: iniciação à linguagem gráfica e cartográfica, concurso Cartografia para crianças, atlas escolares, a Cartografia no livro didático, materiais paradidáticos, recursos digitais e interativos, interface com artes em geral. As autoras apresentam quatro eixos temáticos, e em cada eixo, indicam os temas pesquisados.

Representação do espaço: nesse eixo incluem as pesquisas de cunho mais teórico sobre a linguagem cartográfica, os mapas mentais, a Etnocartografia e representação de conceitos sócio espaciais.

Metodologia de ensino: Envolve os conteúdos teórico-práticos voltados para a busca de caminhos didáticos no ensino da Cartografia Escolar, incluindo iniciação cartográfica, educação especial (Cartografia Tátil) e ensino-aprendizagem de habilidades e conceitos específicos da Cartografia nos três níveis da educação básica (anos iniciais e finais do ensino fundamental e ensino médio).

Tecnologias e produção de materiais didáticos cartográficos: inclui as pesquisas sobre atlas escolares, maquetes, Cartografia multimídia, mapas e internet, educação a distância, sensoriamento remoto e geoprocessamento aplicados ao ensino de Geografia.

Formação de professores e currículo: inclui as pesquisas sobre saberes e práticas docentes, cotidiano escolar, cultura, currículo e formação de professores.

As autoras destacam dois campos da Cartografia Escolar que têm crescido bastante nos últimos anos, a saber: Cartografia Tátil e Etnocartografia. Segundo as pesquisadoras, "Etnocartografia e Cartografia tátil são exemplos de metodologias e iniciativas que trabalham para os direitos de todos os cidadãos, incluindo crianças e jovens, dando-lhes as mesmas oportunidades que os demais" (ALMEIDA; ALMEIDA, 2014. p. 88).

Após mais de 30 anos de iniciativas positivas e resultados impressionantes, tais como o número de publicações, eventos científicos organizados, materiais didáticos e paradidáticos, a área da Cartografia Escolar no Brasil enfrenta grandes desafios para o futuro. Um deles é o de encontrar formas inovadoras para direcionar suas ações e realizações no âmbito da sala de aula. Em geral, pesquisas e publicações deverão abordar questões teóricas, conhecimento aplicado e práticas educativas em Cartografia Escolar. (ALMEIDA; ALMEIDA 2014).

Passados quase 40 anos da origem da Cartografia Escolar como linha de pesquisa, percebe-se que muito já foi feito, porém os desafios ainda existem para que essa linha de pesquisa possa fazer parte da formação inicial do professor de Geografia como um componente curricular e seu reflexo na educação básica seja sentido em curto e médio prazo em todo o território nacional.

Vale a pena citar que iniciativas positivas têm sido feitas, como o crescente número de projetos de PIBID que procuram empregar a linguagem cartográfica no ensino de Geografia como princípio metodológico. Os professores da educação básica são conscientes da necessidade de ensinar e utilizar a linguagem 
cartográfica em sala de aula, porém muitos deles não têm o preparo suficiente para isso. Esse problema acompanha o professor desde a formação inicial e perdura na prática pedagógica, pois estados e municípios não oferecem formação continuada. Esse é um dos maiores desafios da Cartografia escolar para os próximos anos.

Para tanto, os cursos de formação de professores desconhecem essa necessidade e mantem seus currículos recheados de componentes curriculares mais ligados ao bacharelado do que à licenciatura. Para não concluir e sim possibilitar novos horizontes para a pesquisa nessa linha, considera-se de fundamental importância um questionamento que não necessita de uma resposta imediata e sim de uma reflexão. Até que ponto o professor do ensino superior, responsável em parte pela formação do professor da educação básica, conhece a realidade da educação?

\subsection{LUGAR DA CARTOGRAFIA ESCOLAR NO CURRÍCULO DE GEOGRAFIA}

Como visto na parte anterior, a Cartografia Escolar tem se destacado entre um dos temas pesquisados nos eventos acadêmicos no Brasil (PINHEIRO, 2005a; CAVALCANTI, 2010; BUITONI, 2014; CALLAI et. al., 2016). Apesar dos inúmeros trabalhos publicados nos últimos anos sobre os assuntos referentes à Cartografia e sua relação com a Educação e a Geografia, seja na forma de livro, capítulo de livro, artigos de periódico e/ou trabalhos em eventos nacionais e regionais, é necessário ressaltar a importância da obrigatoriedade do uso da linguagem cartográfica nos livros didáticos de Geografia utilizados na escola, como está inserido nos guias, propostas, orientações e parâmetros curriculares. A linguagem cartográfica, tão peculiar à ciência geográfica, ainda é pouco usada em sala de aula, demonstrando a dificuldade de professores e alunos dos variados níveis de ensino em lidarem com os conceitos cartográficos.

Os Parâmetros Curriculares Nacionais (PCN) de Geografia (6o ao 9o ano) indicam um eixo do terceiro ciclo, "A Cartografia como instrumento na aproximação dos lugares e do mundo", em que se enfatiza a importância da Cartografia para o ensino e aprendizagem da Geografia Escolar, já que

[...] a Cartografia torna-se recurso fundamental para o ensino e a pesquisa. Ela possibilita ter em mãos representações dos diferentes recortes desse espaço e na escala que interessa para o ensino e pesquisa. Para a Geografia, além das informações e análises que se podem obter por meio dos textos em que se usa a linguagem verbal, escrita ou oral, torna-se necessário, também, que essas informações se apresentem especializadas, com localizações e extensões precisas, e que possam ser feitas por meio da linguagem gráfica/cartográfica. É fundamental, sob o prisma metodológico, que se estabeleçam as relações entre os fenômenos, sejam eles naturais ou sociais, com suas espacialidades definidas. (BRASIL, 1998, p. 76)

Figura 10 - Conteúdo do terceiro ciclo do ensino fundamental.

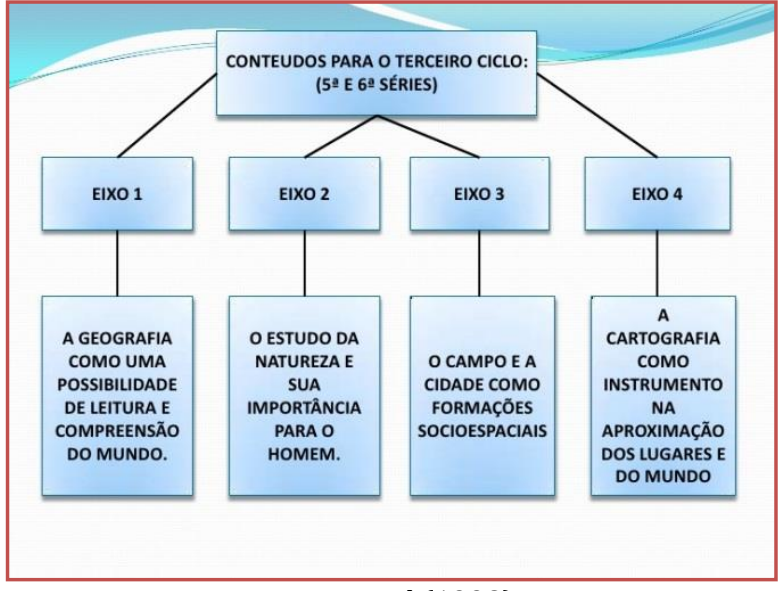

Fonte: Brasil (1998) 
Na tentativa de encontrar respostas para uma das questões norteadoras deste trabalho, referente ao lugar da linguagem cartográfica no currículo escolar, buscou-se suporte nos PCN, no Referencial Curricular de Geografia do ensino fundamental do 6으 ao 9o ano do estado do Maranhão e o texto final do componente Geografia da Base Nacional Comum Curricular.

É importante frisar que tanto os PCN quanto a BNCC não representam o currículo praticado pelas escolas, seja no nível estadual ou municipal. Esses documentos constituem um referencial nacional para que, a partir deles, os estados, municípios e escolas possam construir seus respectivos currículos.

Figura 11 - Mapa conceitual da Cartografia no ensino fundamental.

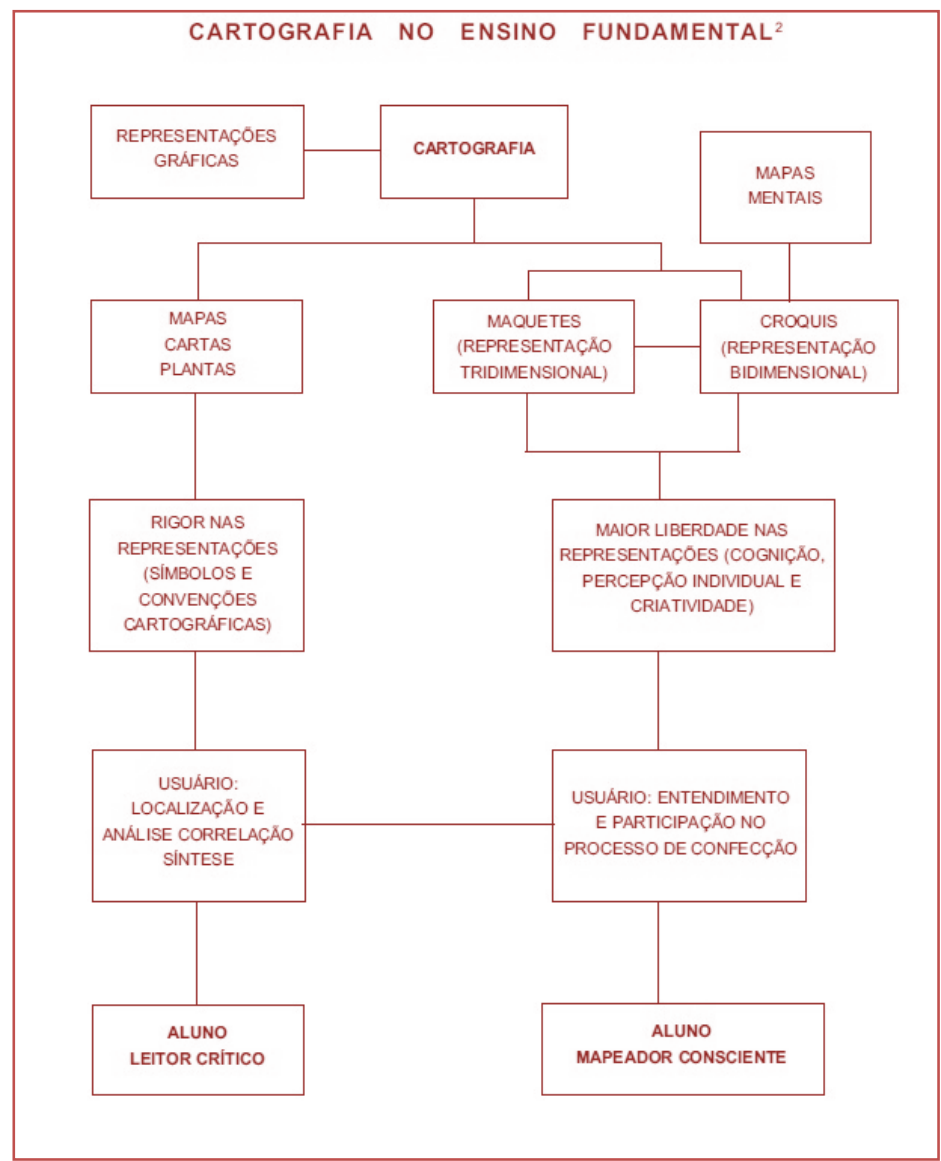

Fonte: Brasil (1998)

Dito isso, parte-se para a análise dos documentos na ordem em que foram citados nos parágrafos anteriores. Os PCN, elaborados e aprovados em 1998, apresentaram uma proposta de trabalhar a Cartografia no terceiro ciclo (6ํㅜ e 7ํano) do ensino fundamental como eixo temático e dentro do eixo abordar dois temas (ver Quadro 17). Num primeiro momento, propõe-se iniciar o processo de alfabetização cartográfica e, em seguida, a leitura autônoma do mapa. Para tal, foram utilizados dois mapas conceituais construídos por Simieli (1986).

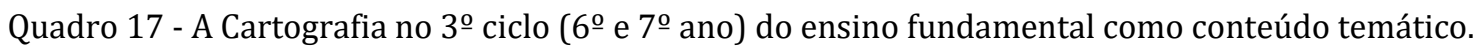

\begin{tabular}{|l|l|}
\hline \multicolumn{2}{|c|}{ Eixo } \\
$\begin{array}{l}\text { Eixo 4: A Cartografia como instrumento na aproximação } \\
\text { dos lugares e do mundo. }\end{array}$ & $\begin{array}{l}\text { Da alfabetização à leitura crítica e mapeamento } \\
\text { consciente. }\end{array}$ \\
\cline { 2 - 2 } & $\begin{array}{l}\text { Os mapas como possibilidade de compreensão e estudos } \\
\text { comparativos das diferentes paisagens e lugares. }\end{array}$ \\
\hline
\end{tabular}


Com base nos dados do quadro acima, a Cartografia aparece como sugestão de conteúdo a ser ministrado no $3^{\circ}$ ciclo, que corresponde ao $6^{0}$ e $7^{\circ}$ ano do atual currículo do ensino fundamental de nove anos. 0 retrato da fidelidade à proposta apresentada nos PCN está nos livros didáticos utilizados na escola, nos quais os conteúdos de Cartografia são inseridos no 6ํㅜ ano e em raros casos aparecem nas séries subsequentes, seja no final das unidades ou como anexo no final do livro.

Poucos estados ousaram construir seus currículos de forma a atender as necessidades locais ou regionais. A maioria construiu um currículo na tentativa de atender aos critérios estabelecidos pelo Programa Nacional do Livro Didático (PNLD) a partir de 2010, ou seja, o conteúdo do livro didático serviu muito mais de referência para a elaboração ou reformulação dos currículos de alguns estados e municípios do que os PCN. Um exemplo claro dessa realidade foi a elaboração do currículo maranhense, que resultou na rejeição do mesmo pela maioria dos municípios do estado.

A seguir, passa-se a analisar a estrutura e composição do currículo do Maranhão, reformulado e aprovado em 2010. Com o nome de Referencial Curricular de Geografia para o ensino fundamental do $6^{\circ}$ ao $9^{\circ}$ ano (RCGEF), o referido documento apresenta a proposta de trabalhar as quatro séries que compõem os anos finais do ensino fundamental a partir de eixos temáticos, como representado no quadro abaixo.

Quadro 18 - A Linguagem Cartográfica no Currículo de Geografia do Ensino Fundamental anos finais no Maranhão.

\begin{tabular}{|c|c|}
\hline Eixos & Características \\
\hline $\begin{array}{l}\text { Linguagem e } \\
\text { representação } \\
\text { cartográfica }\end{array}$ & $\begin{array}{l}\text { Destaca a necessidade de trabalhar a Cartografia de forma contextualizada e inserida } \\
\text { no decorrer do desenvolvimento dos conteúdos ao longo da etapa dos anos finais do } \\
\text { ensino fundamental. }\end{array}$ \\
\hline $\begin{array}{l}\text { A construção do espaço } \\
\text { brasileiro e maranhense }\end{array}$ & $\begin{array}{l}\text { Prioriza o reconhecimento do espaço geográfico maranhense e brasileiro, dando } \\
\text { ênfase ao estado do Maranhão de forma a contextualizar a realidade brasileira e local } \\
\text { com a dinâmica mundial, nos diversos conteúdos disciplinares e dos temas social ao } \\
\text { longo da etapa dos anos finais do ensino fundamental. }\end{array}$ \\
\hline $\begin{array}{l}\text { Meio ambiente e } \\
\text { sociedade }\end{array}$ & $\begin{array}{l}\text { A proposta de Geografia para o estudo das questões ambientais favorece ao aluno a } \\
\text { concepção clara dos problemas de ordem local, regional e local a compreensão e a } \\
\text { formação de novas atitudes em relação ao desenvolvimento de um ambiente } \\
\text { saudável. }\end{array}$ \\
\hline $\begin{array}{l}\text { Globalização: produção } \\
\text { consumo e tecnologia. }\end{array}$ & $\begin{array}{l}\text { Enfatiza o estudo das grandes mudanças ocorridas como resultado do processo de } \\
\text { globalização. A análise deve permitir a comparação entre o Brasil e outras realidades } \\
\text { do mundo capitalista, aprofundando os fenômenos sociais, econômicos, políticos, } \\
\text { culturais e ambientais que acontecem no espaço geográfico mundial. }\end{array}$ \\
\hline
\end{tabular}

Fonte: Maranhão (2010). Organização dos atores.

Os quatro eixos definidos no RCGEF seguem a mesma estrutura para as quatro séries que compõem os anos finais do ensino fundamental, mudando apenas capacidades e conteúdos básicos. No referido documento, a linguagem cartográfica aparece como primeiro eixo como o nome "Linguagem e Representação Cartográfica". Nesse eixo é sugerido o emprego da linguagem cartográfica ao trabalharem com os conteúdos específicos da Geografia.

Como dito anteriormente, poucos municípios maranhenses usam esse documento como currículo, haja vista que, após sua aprovação e publicação, não houve a formação continuada prevista no projeto inicial. Diante do descumprimento desse item da proposta, alguns municípios se recusaram a trabalhar com o novo currículo. No entanto, algumas escolas têm procurado definir o que chamam de currículo mínimo para o ensino fundamental, ou seja, conteúdos considerados importantes para a formação básica em cada componente curricular.

Desde 2015 se presencia o processo de reformulação do currículo nacional da educação básica, restando apenas a apresentação do texto final do ensino médio. Para muitos, o texto final do ensino fundamental apresenta avanços, para outros o documento é um retrocesso à educação do país. No entanto, vale frisar que a BNCC, assim como foi com os PCN, não será considerada o currículo nacional e sim uma base para que, a partir dela, os estados, municípios e escolas possam reformular ou até mesmo criar seus respectivos currículos. 
No quadro a seguir são apresentadas as unidades básicas consideradas eixos organizadores dos conteúdos escolares, seguidas das características, ou seja, o que se espera alcançar ao final de cada unidade temática.

Quadro 19 - A Cartografia na BNCC de Geografia no Ensino Fundamental anos finais.

\begin{tabular}{|l|l|}
\hline \multicolumn{2}{|c|}{ Unidades temáticas } \\
\hline C sujeito e seu lugar no mundo. & Focalizam-se as noções de pertencimento e identidade. \\
\hline Conexões e escalas. & $\begin{array}{l}\text { Promover articulação de diferentes espaços e escolas de análise, } \\
\text { possibilitando que os alunos compreendam as relações existentes entre fatos } \\
\text { nos níveis local e global. }\end{array}$ \\
\hline Mundo do trabalho. & $\begin{array}{l}\text { Abordam-se os processos e as técnicas construtivas e o uso de diferentes } \\
\text { materiais produzidos pelas sociedades em diversos tempos. }\end{array}$ \\
\hline $\begin{array}{l}\text { Formas de representação e } \\
\text { pensamento espacial. }\end{array}$ & $\begin{array}{l}\text { Promover ampliação gradativa da concepção do que é um mapa e de outras } \\
\text { formas de representação gráfica são reunidas aprendizagens que envolvam o } \\
\text { raciocínio geográfico. }\end{array}$ \\
\hline $\begin{array}{l}\text { Natureza, ambiente e qualidade de } \\
\text { vida. }\end{array}$ & $\begin{array}{l}\text { Busca-se a unidade da Geografia, articulando Geografia Física e Geografia } \\
\text { Humana, com destaque para a discussão dos processos físico-naturais do } \\
\text { planeta Terra. }\end{array}$ \\
\hline
\end{tabular}

Fonte: Brasil (2017). Organização dos autores.

Na BNCC para o ensino fundamental de nove anos, as cinco unidades temáticas definidas seguem o currículo do $1^{\circ}$ ao $9^{\circ}$, mudando apenas os objetos de conhecimentos e as habilidades. Vale destacar que a unidade temática "Formas de representação e pensamento espacial" indica a possibilidade de inserção da tão sonhada "alfabetização cartográfica" desde os anos iniciais, como defendem os pesquisadores da Cartografia Escolar que têm dedicado seus estudos ao processo de iniciação a leitura e interpretação de mapas (PASSINI, 2012). 


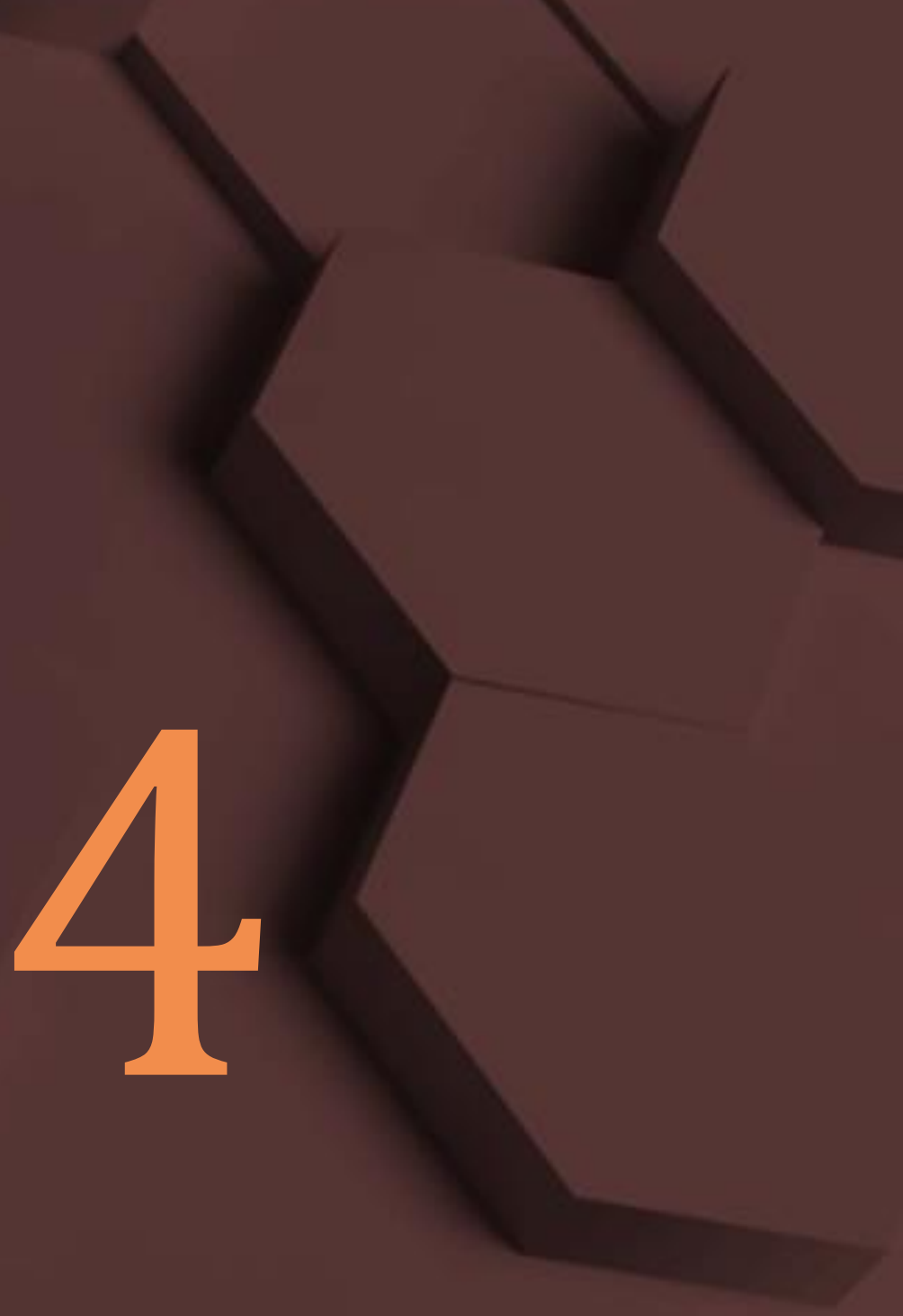

Teoria da Ação Comunicativa e a Dimensão da Linguagem 
Uma breve reflexão do retrato da educação no Brasil se faz necessária para que possamos entender a necessidade de mudanças não só na estrutura do currículo, mas na forma de pensar e agir diante da realidade que se apresenta. Acredita que os educadores, tanto os que se dedicam à pesquisa e formação de professores para atuação na educação básica, quanto os envolvidos diretamente na atividade docente da educação básica, enfrentam uma realidade educativa imersa em perplexidades, crises, incertezas, pressões sociais e econômicas, relativismo moral, dissoluções de crenças e utopias. Talvez a palavra que melhor representa este momento seja a precarização do trabalho docente.

O reflexo de tudo isso dá-se exatamente na sala de aula, onde decisões precisam ser tomadas e ações imediatas e pontuais precisam ser efetivadas visando a promover mudanças qualitativas no desenvolvimento e na aprendizagem dos sujeitos. Pensar e agir no campo da educação, enquanto atividade social prática de humanização das pessoas, implica responsabilidade social e ética de dizer não apenas o porquê fazer, mas o que fazer e como fazer. Isso envolve necessariamente uma tomada de posição, que revela exatamente o tipo de racionalidade que orienta a tomada de decisões dos responsáveis pelo processo educativo, não só a pessoa do professor, mas todos os atores envolvidos no processo.

Vale ressaltar que a escola existe para formar sujeitos preparados para sobreviver na sociedade e, para isso, precisam da ciência, da cultura, da arte, precisam saber de coisas, saber resolver dilemas, ter autonomia e responsabilidade diante de suas ações, saber dos seus direitos e deveres, construir sua dignidade humana, ter uma autoimagem positiva, desenvolver capacidades cognitivas para se apropriar criticamente dos benefícios da ciência e da tecnologia em favor do seu trabalho, da sua vida cotidiana, do seu crescimento pessoal e coletivo, mesmo sabendo que essas aprendizagens impliquem saberes originados nas relações cotidianas e experiências socioculturais, isto é, a cultura da vida cotidiana.

É notório que o modelo de ciência ainda presente nas instituições de pesquisa e formação de professores não tem dado conta de atender tais necessidades a partir dos currículos, normas e diretrizes para a formação de professores. Pesquisas e mais pesquisas são desenvolvidas, novas metodologias são anunciadas, grupos de pesquisa e novas linhas de pesquisas são criadas e/ou redesenhadas. Mas os resultados de tais pesquisas não têm chegado às escolas da educação básica, ou tem chegado de forma tímida. O que está faltando então? A universidade responsável pela formação inicial do professor da educação básica tem conhecimento da realidade para a qual está formando estes profissionais? 0 currículo criado pela universidade leva em conta a dimensão da cultura, da sociedade e do indivíduo no processo de formação? Qual o perfil do profissional formado pela universidade hoje? Inúmeros questionamentos podem ser feitos com relação à problemática apresentada, mas acredita-se que um deve ser mais relevante: que paradigmas têm norteado as pesquisas ligadas ao campo da educação geográfica no Brasil?

Não existem respostas satisfatórias para tantos questionamentos. Buscando na literatura nacional, tem-se as reflexões de Libâneo (2005) que, ao falar das teorias pedagógicas, destaca o papel das teorias ditas críticas ou usa a designação "sociocrítica" quando se refere às mesmas. Segundo o autor, esse termo está sendo utilizado para ampliar o sentido de "crítica" e abranger teorias e correntes que se desenvolvem a partir de referenciais marxistas ou neomarxistas (e mesmo apenas de inspiração marxista) e que são frequentemente divergentes entre si, principalmente quanto a premissas epistemológicas. As abordagens sociocríticas, segundo o autor, convergem na concepção de educação como compreensão da realidade para transformá-la, visando à construção de novas relações sociais para superação de desigualdades sociais e econômicas. Dentre as teorias pedagógicas modernas ditas "sociocríticas", o autor destaca a Teoria da Ação Comunicativa (TAC) de Habermas, que interessa neste trabalho, pois é a partir da Teoria Crítica que se buscou fazer uma aproximação da Teoria de Habermas com a linguagem cartográfica com vistas a transformação das práticas docentes de professores de Geografia da educação básica.

Para Libâneo (2005), a TAC, formulada por J. Habermas, está associada à Teoria Crítica da Educação originada dos trabalhos da Escola de Frankfurt. Essa teoria realça no agir pedagógico a ação comunicativa, entendida como interação entre sujeitos por meio do diálogo para se chegar a um entendimento e cooperação entre as pessoas nos seus vários contextos de existência. Constitui-se, assim, numa Teoria da Educação assentada no diálogo e na participação, visando à emancipação dos sujeitos.

O que difere então a Teoria Crítica da Escola de Frankfurt das outras teorias ditas sociocríticas na visão de Libâneo (2005)? Buscou-se explicitar algumas características específicas desta teoria e de seus pensadores nos parágrafos a seguir, bem como tentar mostrar a evolução das gerações que formaram na referida escola, que para muitos já se encontra na terceira geração. São utilizadas então, além das características do pensamento dessa escola, os principais pensadores de cada uma das gerações. 
Para o cumprimento desta tarefa, recorreu-se ao trabalho de Barbara Freitag (1995), no qual ela cita alguns dos temas mais estudados pelos membros da Escola de Frankfurt entre 1920 e 1985, que foram os seguintes:

- $\quad$ A dialética da razão iluminista e a crítica à ciência;

- $\quad$ A dupla face da cultura e a discussão da indústria cultural;

- $\quad$ A questão do Estado e suas formas de legitimação na moderna sociedade de consumo;

- Uma Teoria Crítica permeada pelo desencanto com a realidade, o que faz com que ela seja uma "escola do desencantamento".

O objetivo dos fundadores da Escola de Frankfurt e de toda a primeira geração era apresentar um modelo de marxismo que pudesse ser uma alternativa ao conflito que dividia o próprio pensamento marxista e, por isso, pode-se dizer que o Instituto de Pesquisa Social nasceu dentro da tradição marxista e tinha o firme propósito de continuar esse legado. 0 primeiro objetivo do Instituto e da Teoria Crítica foi, portanto, reunir pesquisadores de diferentes especialidades de forma interdisciplinar, tendo como referência comum o marxismo (NOBRE, 2004).

Os principais autores da primeira geração da Escola de Frankfurt foram Max Horkheimer, Theodor Adorno, Herbert Marcuse e Walter Benjamim, que contribuíram para o fomento da Teoria Crítica (FREITAG, 1995). O pensamento crítico dos filósofos da Escola de Frankfurt tinha em comum o direcionamento de suas críticas à ordem política e econômica do "mundo administrado". Essa ordem vigora aos moldes de um aparato tecnológico que, de certa forma, incide na sociedade o seu condicionamento padronizado, homogêneo e, sobretudo, sem a perspectiva de empreender a vida de cada indivíduo de forma autônoma.

A Teoria Crítica não se limita a descrever o funcionamento da sociedade, mas pretende compreendê-la à luz de uma emancipação ao mesmo tempo possível e bloqueada pela lógica própria da organização social vigente [...] sendo efetivamente possível uma sociedade de mulheres e homens livres e iguais. (NOBRE, 2004, p. 09)

Quando o Instituto de Pesquisa Social retorna para Frankfurt no período pós-guerra, começa a se formar a segunda geração de pensadores sociais da Escola de Frankfurt, dos quais Jürgen Habermas e Karl Otto Apel se tornam seus mais eminentes representantes. Habermas ingressou na Escola em 1962, com a publicação de sua tese de doutorado: Mudança estrutural da esfera pública. Dez anos depois, Karl Otto Apel também ingressa em Frankfurt como catedrático em filosofia; no ano seguinte publicou o artigo $\mathrm{O}$ a priori da Comunidade de Comunicação, lançando as bases de um novo paradigma pragmático para a Filosofia, considerando o fato da comunicação estar na base de todo discurso científico, resultando disto que, para uma norma ser considerada válida, seria necessário, além da livre aceitação de um acordo, os esclarecimentos que devem atender às exigências de justificação dos ouvintes que participam da conversação. Ele teve o apoio de Habermas nessa virada epistemológica e filosófica para um novo conceito de racionalidade que tem, a partir de então, a comunicação como sua forma de sustentação. Habermas procura fundamentar a sua Teoria Crítica em uma filosofia da linguagem, tendo como base uma pragmática universal e servindo de base para a ação comunicativa (SILVA, 2001).

A partir de 1996, tem início o que alguns estudiosos chamam de terceira geração da Escola de Frankfurt. Em maio de 2001, Axel Honneth assumiu a direção do Instituto de Pesquisa Social, depois de ter sido assistente de Habermas no Instituto de Filosofia da Universidade de Frankfurt, entre 1984 e 1990, e sucedido Habermas em seu posto em 1996. Apesar disso, para Nobre (2004), Honneth não pode ser considerado como um integrante da Escola de Frankfurt, pois "tal como Habermas, também Honneth apresentou primeiramente sua própria posição teórica em contraste e confronto com seus antecessores" (NOBRE, 2004, p. 10) e a despeito de não ser um integrante da Escola, "parece-me correto, entretanto, incluí-lo na tradição da Teoria Crítica" (id., ibidem, p. 10). Honneth critica o posicionamento de Habermas na busca de um consenso e entendimento como método de procedimento de se fazer política, sem considerar que o conflito e a luta por reconhecimento constituem a base das interações e ações sociais.

A figura mais proeminente dentre os teóricos da terceira geração de Frankfurt é Axel Honneth. Os seus estudos concentram-se nas áreas: filosofia social, política e moral, tratando, principalmente, da explicação teórica e crítico-normativa das relações de poder, respeito e reconhecimento na sociedade atual. (SALVADORI, 2011, p. 189) 
Dito isso, o que interessa a partir de agora é entender a arquitetura do projeto da TAC de Habermas para poder então analisar a possibilidade de aproximação dos pressupostos teóricos da referida teoria com os elementos da Linguagem Cartográfica (LC).

\subsection{UM POUCO SOBRE JÜRGEN HABERMAS}

Jürgen Habermas é um importante filósofo e sociólogo do século XX. Nasceu em Dusseldorl, na Alemanha, em 1929, é conhecido pelas teorias sobre a racionalidade comunicativa e a esfera pública. No presente trabalho, será abordado a racionalidade comunicativa e sua aproximação com a linguagem cartográfica, com vista à orientação do trabalho pedagógico de professores que ministram aulas de Geografia nos anos finais do ensino fundamental.

Com relação à vida acadêmica, Jürgen Habermas licenciou-se em 1954 na Universidade de Bonn, com a tese intitulada 0 absoluto e a história. No período de 1956 a 1959 foi auxiliar de Theodor Adorno, em Frankfurt. No início da década de 1960 realizou pesquisas sobre a participação estudantil na política alemã, intitulada Estudante e política.

Em 1968, Habermas mudou-se para Nova York para lecionar na New School for Social Research (Nova Escola de Investigação Social). A partir de 1971 foi diretor do Instituto Max Planck, em Starnberg, na Baviera, Alemanha. Em 1983 foi para a Universidade Johann Wolfgang Von Goethe, de Frankfurt, até se aposentar em 1994. Porém, continua publicando e participando de debates e atuando em jornais como cronista político.

Habermas é considerando um dos principais herdeiros das discussões da Escola de Frankfurt, uma das bases da corrente do Marxismo Ocidental. Não obstante, superou o pessimismo dos fundadores da Escola ao apresentar um projeto moderno para ela, pois, com as ideias iluministas e os desastres da Segunda Guerra Mundial, houve predominância entre conhecimento racional e a dominação social, o que resultou numa espécie de falência das ideias modernas de emancipação social.

Em seu projeto filosófico, Habermas adota o paradigma comunicacional. 0 ponto de partida é a ética comunicativa inspirada em Karl Otto Apel e no conceito de "razão objetiva", de Adorno, também presente na filosofia de Platão, Aristóteles e no Idealismo alemão hegeliano. Com isso, Habermas dá origem à razão comunicativa - e à ação comunicativa, isto é, a comunicação livre, racional, crítica e emancipatória - como alternativa e superação da razão instrumental e iluminista. Esse, portanto, é o projeto moderno empreendido no desejo de restabelecer vínculos entre o Socialismo e a democracia.

Para Habermas, existem na sociedade duas esferas: o sistema e o mundo da vida. 0 sistema trata da "reprodução material", dirigido pela lógica instrumental das adequações de meios e fins nas relações do poder político e poder econômico. Já o mundo da vida refere-se ao espaço social em que a ação comunicativa permite a realização da razão comunicativa, calcada no diálogo e na força do melhor argumento em contextos interativos, livre de coação.

Os estudos de Habermas também se voltam para o conhecimento e a ética. Habermas explica a produção do saber humano recorrendo ao Evolucionismo, pois a racionalidade comunicativa é "aprendente". A falibilidade, por exemplo, possibilita desenvolver capacidades mais complexas de conhecer a realidade e se evoluir através dos erros, entendidos como falhas de coordenação de planos de ação.

Habermas defende uma ética universalista, deontológica (ciência que estuda o dever, a obrigação), formalista e cognitivista. Os princípios éticos não devem ter conteúdo, mas garantir a participação dos interessados nas decisões públicas através de discursos, em que se avaliam os conteúdos normativos a partir das necessidades naturais da vida.

Suas teorias discursivas também são aplicadas à filosofia jurídica, pela característica de integração social em prol da democracia e da cidadania. A teoria coloca a possibilidade de resolução dos conflitos vigentes na sociedade pelo viés do consenso de todos. Com isso, ele pretende dar fim à arbitrariedade, propondo a participação ativa e igualitária de todos os cidadãos em busca de justiça. Para Habermas, essa forma consiste no agir comunicativo que se manifesta e ramifica no discurso.

Para um indivíduo garantir seu sucesso, faz-se necessário perseguir seus interesses individuais, organizando uma estratégia baseada em ações. Para a sociedade, Habermas, defende a organização partindo da ação estratégica para a ação comunicativa. Ação que ultrapassa o sucesso individual para o entendimento mútuo, abrindo diálogo para pensar em conjunto o bem social. 
No tocante à importância de Habermas no cenário internacional destaca-se inicialmente os países com maior número de estudos utilizando a Teoria da Ação Comunicativa e o conceito de racionalidade; destacam-se os seguintes países que mais publicam sobre Habermas: EUA, Inglaterra, Canadá, Alemanha e Brasil. Dentre as áreas de maior volume de publicações estão: Ciências Políticas, Filosofia, Sociologia, Direito, Comunicação e Ciências Sociais, incluindo a Educação.

Já com relação aos principais periódicos com publicações sobre os estudos de Habermas temos os representados na tabela abaixo.

Tabela 8 - Relação dos periódicos com publicações sobre Habermas.

\begin{tabular}{|c|c|}
\hline Periódicos & Número de Artigos \\
\hline Journal of Planning Education and Research & 6 \\
\hline Deutsche Zeitschrift fur Philosophie & 3 \\
\hline Journal of Communication & 3 \\
\hline New German Critique & 3 \\
\hline Philosophy Social Criticism & 3 \\
\hline
\end{tabular}

Fonte: Machado et. al. (2017).

No cenário brasileiro, as áreas de destaque são: Direito, Filosofia, Administração, Comunicação e Educação. Na área da Educação, encontram-se disponíveis algumas teses, dissertações, livros, anais de eventos e artigos. A difusão dos trabalhos e ideias de Habermas no Brasil ganham destaque com a realização de eventos chamados de Colóquio Habermas, presididos pelo Grupo de Pesquisa: Filosofia e Política da Informação do Instituto Brasileiro de Informação em Ciência e Tecnologia (IBICT); a XIII edição do evento foi realizada em setembro de 2017, no Rio de Janeiro, e a XIV será realizada em Santa Catarina, em meados de setembro de 2018.

Não foi possível o acesso a informações referente a todas as edições do referido evento. No site do IBICT estão disponíveis todas as informações, bem como os anais das últimas nove edições, sendo que as três primeiras foram realizadas na forma de espaço de diálogo entre os membros do grupo de pesquisa. No quadro abaixo segue a descrição das edições do evento, seguido da temática, cidade onde o evento foi realizado e o ano.

Quadro 20 - Edições do Colóquio Habermas

\begin{tabular}{|c|l|c|c|}
\hline EDIÇÃO & \multicolumn{2}{c}{ TEMA } & LOCAL \\
\hline V Colóquio & O pensamento vivo de Habermas uma visão interdisciplinar & Florianópolis & 2008 \\
\hline VI Colóquio & Ideologia e crítica na Teoria da Ação Comunicativa & Rio de Janeiro & 2010 \\
\hline VII Colóquio & Esfera pública pós-secular: tolerância ou reconhecimento? & Londrina & 2011 \\
\hline VIII Colóquio & Mudança estrutural na esfera pública 50 anos depois. & Rio de Janeiro & 2012 \\
\hline IX Colóquio & Habermas e os sentimentos morais & Rio de Janeiro & 2013 \\
\hline X Colóquio & "Representação, democracia e controle social” & Rio de Janeiro & 2014 \\
\hline XI Colóquio & Os limites para a liberdade comunicativa & Rio de Janeiro & 2015 \\
\hline XII Colóquio & Conflitos contemporâneos: direitos humanos e solidariedade & Rio de Janeiro & 2016 \\
\hline XIII Colóquio & A inclusão do outro & Rio de Janeiro & 2017 \\
\hline
\end{tabular}

Fonte: IBICT (2018) disponível em: https://coloquiohabermas.wordpress.com. Organização dos autores.

Para Freitag (1995), a Teoria da Modernidade é parte integrante da TAC, juntamente com o conceito de sociedade a partir de duas perspectivas. A primeira perspectiva seria a objetiva, externa (sistêmica); a segunda, subjetiva interna (mundo da vida). A partir de então dar-se-á o resgate do conceito de 
racionalidade dialógica. Para a autora, a Teoria da Modernidade pode ser entendida como uma "Teoria Evoluída"; nesse sentido, considera-se evoluída pelo fato da mesma estar preocupada em reconstruir os processos de formação, os princípios de organização e as crises pelas quis passam as formações societárias no decorrer do tempo.

Mas, afinal, o que se pode entender como "modernidade"? A modernidade refere-se ao período histórico compreendido entre os séculos XVIII-XX a partir de três eventos históricos, a saber: a Reforma Protestante, o Iluminismo e a Revolução Francesa. Com relação ao recorte espacial de ocorrências destes eventos, ocorre inicialmente na Europa e propaga-se pelo Hemisfério Norte, em especial os países banhados pelo Atlântico Norte.

As patologias da Modernidade e os processos de colonização ${ }^{1}$ e emancipação ${ }^{2}$. Freitag (1995) aponta duas patologias da modernidade sendo: 1. Dissociação: entendida como a separação ou quebra do elo entre o "sistema" e o "mundo da vida", fazendo com que os homens modernos submetam suas vidas às leis do mercado e à burocracia estatal, como se fossem forças estranhas contra as quais não há nada a se fazer. Isso permite que a economia e o Estado sejam controlados por uma minoria de homens de negócios e políticos que determinam as regras do jogo dos processos societários contemporâneos, sem consultar a maioria. 2. Racionalização: entendida como a contaminação dos subsistemas capital e poder e por atingir os elementos constitutivos do mundo da vida. Em decorrência do que acontece com a primeira, o sistema vai se fortalecendo em detrimento do mundo da vida, passando a impor sua própria lógica e as regras do jogo. Daí a ação comunicativa cotidiana ou o discurso passa a ser dirigida pelos mecanismos de integração sistêmica, ou seja, o capital e o poder.

\subsection{TEORIA DA AÇ̃̃O COMUNICATIVA}

Jürgen Habermas descreve, em sua Teoria Crítica, a grande inquietação a respeito dos efeitos do Positivismo nas sociedades modernas, em que impera a razão técnica e instrumental, própria do capitalismo avançado. Longe de se contentar com essa abordagem, desenvolve suas pesquisas na busca sistemática de um novo entendimento de racionalidade, que se materializa por meio da ação comunicativa. Para o autor, a mudança de paradigma para o da teoria da comunicação possibilitará um retorno às tarefas de uma teoria crítica da sociedade, desde então negligenciadas pela crítica da razão instrumental.

A obra em que Habermas expõe bem detalhadamente a TAC, contém dois volumes, cada um com mais de 500 páginas, publicados originalmente em alemão em 1981. HABERMAS, Jürgen. Theorie des Kommunikativen Handels. Band I. Handlungsrationalität und geselchaftliche Rationalisierung. Frankfut am Main: Suhrkamp, 1981e HABERMAS, Jürgen. Theorie des Kommunikativen Handels. Band II. Zur Kritik der funktionalistischen Vernunft. Suhrkamp: Frankfut am Main, 1981. Traduzido para o espanhol em 1988, HABERMAS, Jürgen. Teoria de la acción comunicativa. Tomo I. Racionalidad de la acción y racionalización social. Madrid: Taurus, 1988 e HABERMAS, Jürgen. Teoria de la acción comunicativa. Tomo II. Crítica de la razón funcionalista. Madrid: Taurus, 1988. Em 2012 a editora Martins Fontes publica a tradução para o português HABERMAS, J. Teoria do agir comunicativo: Racionalidade da ação e racionalização social. Volume I. Tradução de Paulo Astor Soethe. Revisão técnica Flávio Beno Siebeneichler. São Paulo: Editora WMF Martins Fontes, 2012. e HABERMAS, J. Teoria do Agir Comunicativo: Sobre a crítica da razão funcionalista. Volume 2. Tradução Flávio Beno Siebeneichler. - São Paulo: Editora WMF Martins Fontes, 2012

Em sua teoria, Habermas parte do princípio de que os homens são capazes de ação e, para tanto, utilizam a linguagem para a comunicação com seus pares, buscando chegar a um entendimento válido. Portanto, o entendimento é guiado por atos comunicativos e intersubjetivos entre seus participantes.

Sendo assim, a razão comunicacional se dá por meio de relações intersubjetivas na interação de sujeitos que buscam compreender um determinado fato. Das relações intersubjetivas é que se pode discernir a universalização dos interesses numa discussão. É nesse ponto que o fundamento de uma ética da discussão exige a reconstrução de um espaço crítico, aberto e pluralista. Dessa forma, a racionalidade

${ }^{1}$ A colonização refere-se à penetração da racionalidade instrumental e dos mecanismos de integração do dinheiro e do poder no interior das instituições culturais (FREITAG, 1995. p. 145).

2 A emancipação pode ser entendida na perspectiva da Teoria da Ação Comunicativa como uma ação de ser ou de se tornar independente, livre. 
passa a ser vista como uma fonte inspiradora nas ações humanas, com vistas à emancipação dos homens e a um maior entendimento do mundo.

Na relação dialética entre sistema e mundo da vida ocorrem dois processos distintos, segundo Habermas, que são: processo de colonização do mundo da vida pelo sistema (figura 12) e o processo de emancipação do mundo da vida.

Figura 12 - Colonização do mundo da vida pela razão instrumental.

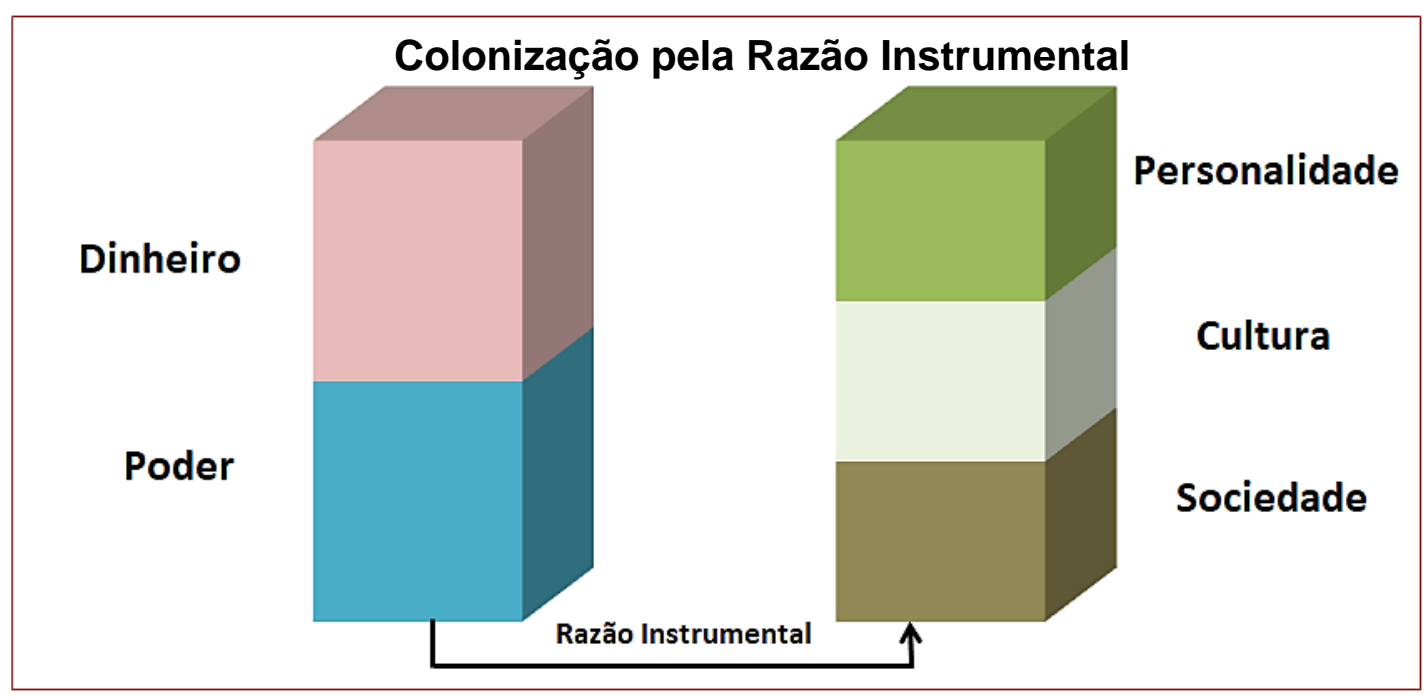

Fonte: Santos (1999)

A compreensão do processo de colonização do mundo da vida pelo sistema deve partir necessariamente do entendimento das racionalidades que conduzem as ações no interior do sistema. Para Habermas (1996), existem duas racionalidades responsáveis pelo processo em discussão, uma racionalidade econômica guiada pelo capital e outra administrativa guiada pelo poder. As variáveis capital e poder juntas invadem as tomadas de decisões no mundo da vida, causando assim sua colonização.

Para Habermas, a emancipação humana e social no contexto contemporâneo não depende mais exclusivamente da categoria trabalho não alienado como ocorria na interpretação marxista. Em vista disso, deve-se, em sua opinião, instaurar uma nova categoria, algo que abrange todas as esferas da vida humana, isto é, uma categoria com função intermediadora das temáticas da racionalidade comunicativa, do sistema e do mundo da vida, e que, além disso, possa subsidiar a discussão e resolução de problemas inerentes à modernidade. Habermas pensa que a única categoria capaz de estabelecer um elo intermediador entre todas as esferas humanas, tanto sociais como individuais, é a linguagem, e é do uso desta que deriva o conceito "ação comunicativa".

Nesse sentido, deve-se compreender a emancipação através do desenvolvimento de pessoas autônomas e racionais numa sociedade democrática, caracterizada por relações dialógicas e recíprocas. Além disso, ressalta-se a importância de focalizar o trabalho com os sujeitos não somente em sala de aula, mas também envolvendo o contexto sociocultural e político no qual a prática educativa se insere, bem como as subjetividades dos sujeitos educativos

Trata-se de um processo de emancipação que combine formas individuais e formas coletivas de cidadania, em que a luta pela emancipação seja igualmente social e do sujeito. É o que defende Boaventura de Sousa Santos (1999), quando procura vincular uma nova teoria da emancipação como sendo o efeito de uma nova teoria democrática que permita reconstruir o conceito de cidadania e uma nova teoria da subjetividade que permita reconstruir o conceito de sujeito. 
Figura 13 - Mapa conceitual representando o processo de Emancipação.

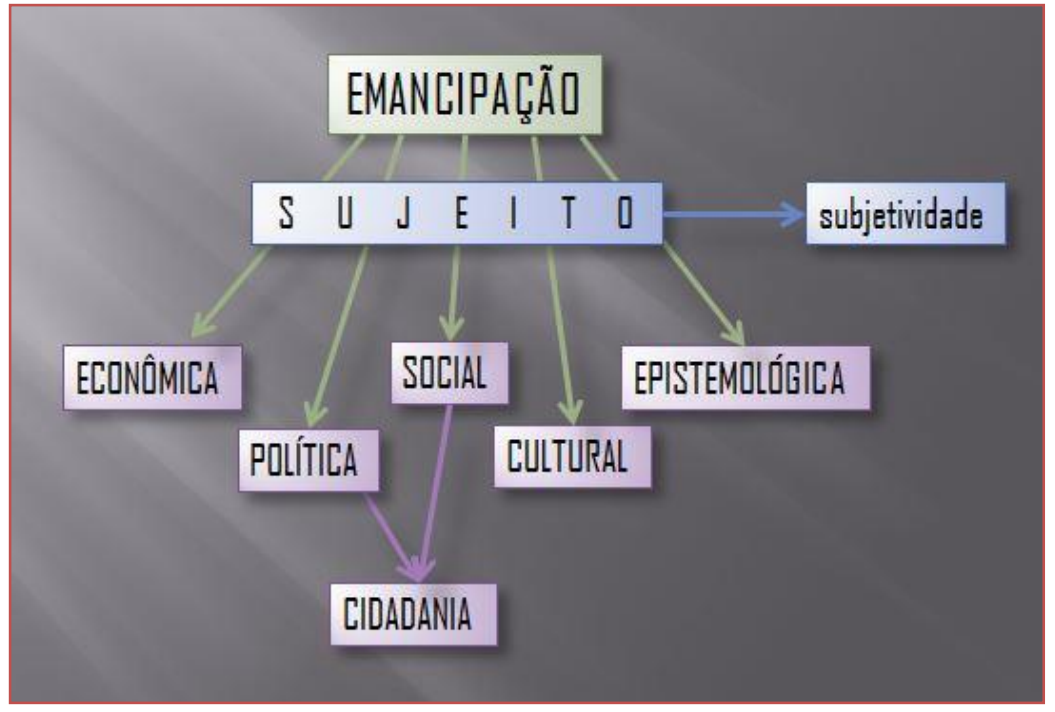

Fonte: Santos (1999)

Enfim, a emancipação humana pressupõe não apenas mudanças nas relações sociais e políticas, mas igualmente nas relações econômicas e de trabalho, se for entendido que é através do seu trabalho que o homem constrói as condições de sua existência individual e social. Habermas propõe então um agir participativo racional como base para o exercício da cidadania e de procedimentos referentes ao discurso relacional entre sujeitos conscientes dos seus direitos e deveres, possível a partir do emprego de uma ética do discurso, elevando o papel da esfera política como sendo um espaço para a construção dos fatores socioeconômicos, políticos e culturais da sociedade.

Habermas mantém o ideal de que a razão humana seja o ponto de partida de um processo de emancipação social, a partir do discurso argumentativo entre sujeitos, ou seja, através do diálogo e de uma relação intersubjetiva os sujeitos devem se posicionar em torno da construção de um modelo de sociedade deliberativo e democrático tendo como horizonte possível a emancipação humana e social.

A linguagem torna-se, então, um diferencial na teoria de Habermas. Podemos-se considerá-la como toda e qualquer forma de comunicação que pode modificar o comportamento. Na concepção habermasiana, a linguagem é concebida como o elo de interação entre os sujeitos, a fim de garantir a democracia das decisões coletivas por meio de argumentações. Na TAC, Habermas pretende investigar a razão, dando a ela um novo conceito: a razão comunicativa. Propõe, então, outro paradigma.

Figura 14 - TAC e sua relação com a Teoria da Racionalidade e Pragmática da Linguagem.

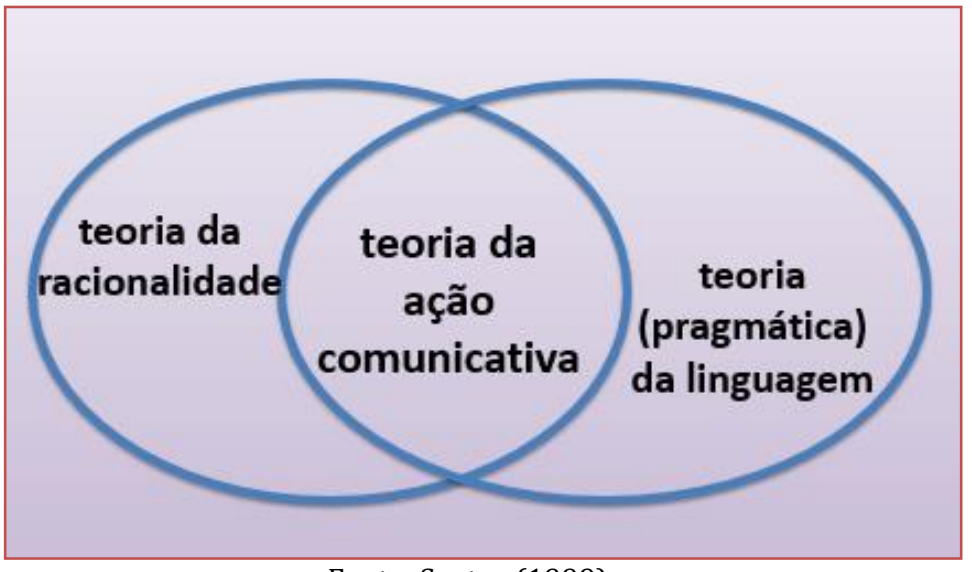

Fonte: Santos (1999). 
O autor propõe a mudança do paradigma da filosofia da consciência para o paradigma da filosofia da linguagem. A mudança de paradigma proposta pelo filósofo supõe não apenas a superação do raciocínio lógico ou do processo de interpretação do conhecimento no qual o sujeito conhece isoladamente, mas principalmente em tomar as ações e os atos de fala e representações como ponto de partida de extrema importância no interior das relações.

Pode-se notar então que o grande salto paradigmático proposto por Habermas em relação ao paradigma anterior não se fundamenta apenas na crítica ao pensamento moderno; foi além. Propôs e construiu toda uma teoria alternativa baseada no paradigma da comunicação, visando o caráter emancipatório dos sujeitos; no entanto, o foco central para este salto paradigmático fundamentou-se numa visão diferenciada de razão e racionalidade.

O mundo da vida é o lugar das relações sociais espontâneas, das reais necessidades dos sujeitos, seus sentimentos e percepções, dos vínculos estabelecidos com seus semelhantes, um nicho pré-científico, intuitivo, não tematizado e inquestionável. Pode-se perceber que o mundo da vida é um conceito que faz parte e completa a ação comunicativa. É o espaço onde se constrói a razão comunicativa, a partir das relações intersubjetivas entre os sujeitos.

Ao elaborar a TAC, Habermas parte de uma filosofia que trata do ser humano como sujeito dotado de linguagem, movido para a compreensão dos fatos. Pela comunicação, o sujeito se depara com as tradições culturais, os ordenamentos sociais e as estruturas de personalidade, elementos que se inter-relacionam de uma forma estreita.

O entendimento que Habermas tem do mundo leva a pensar a sociedade de forma mais ampla, articulada com a subjetividade dos sujeitos que dela partilham, numa relação dialética entre o mundo do sistema e o mundo da vida. As contradições vividas por esses dois mundos são apresentadas como condição de resistência dos sujeitos frente à desestruturação que o mundo do sistema pretende ao tentar controlar o mundo da vida, distanciando-se dele gerando insatisfações, miséria, submissão e violência. Pensar esses conflitos estabelecidos na sociedade remete a pensar a Educação e, mais especificamente, a Educação Escolar, com vistas a compreendê-la nesse emaranhado de relações postas, quer no mundo da vida, quer no mundo do sistema.

\subsection{AS CATEGORIAS DO PENSAMENTO HABERMASIANO}

Entender Habermas não é fácil, ainda mais se tratando de alguém que migra de uma cultura neopositivsta para a Teoria Crítica. No entanto, a busca pelo entendimento do pensamento habermasiano se fazia necessário, portanto a alternativa foi buscar ler quem interpretava o pensamento de Habermas. Além dos artigos, teses e dissertações, um livro merece destaque pela forma como apresenta o filósofo. Trata-se de Compreender Harbermas de Walter Reese-Schäfer. 0 autor faz uma análise das obras originais de Habermas. $O$ capítulo três trata da TAC, e foi o capítulo que ajudou a compreender melhor o pensamento do autor. Além dessa obra é claro, os dois volumes da Teoria do Agir Comunicativo (traduzidos para o português pela editora Martins Fontes) contribuíram para a leitura e captura dos principais conceitos da teoria habermasiana.

Para Habermas, o conhecimento não acontece apenas na interação solitária do sujeito com os objetos, mas na interação da filosofia da consciência com a filosofia da linguagem em que os sujeitos atuam numa relação de reciprocidade em que juntas buscam um entendimento. Mas o que vem a ser filosofia da consciência e filosofia da linguagem?

O autor explica que a filosofia da consciência consiste na relação do sujeito cognoscente com os objetos; por meio desta autoconsciência solitária o mesmo poderia obter pleno conhecimento dos objetos, da sociedade e do mundo que o cerca. Nesse paradigma, o sujeito, dotado de uma razão monológica, estabelece uma relação puramente cognitivo-instrumental com os objetos, não trabalhando a relação intersubjetiva, que é extremamente importante para que se estabeleça uma racionalidade comunicativa

Já a filosofia da linguagem ou da comunicação consiste na relação do sujeito cognoscente com a comunicação, em que, por meio dessa consciência intersubjetiva de dialogicidade, o mesmo poderia obter um saber histórico-dialético contextualizado. Essa filosofia é defendida por Habermas com vistas a superar a abordagem do paradigma do sujeito, próprio de ações positivistas, fragmentadas e conservadoras. Essa superação seria possível quando, numa relação entre sujeitos, utilizam-se de argumentos para tornar a razão mais humana, crítica e social, possibilitando, dessa maneira, uma ação mais eficaz à emancipação dos homens e ao entendimento da sociedade. 
Para ter uma maior compreensão do processo pelo qual a racionalidade foi entendida durante séculos, Siebeneichler descreve a grande mudança de paradigma com a qual Habermas se defrontou a partir da década de 70:

Se vê confrontado com dois paradigmas possíveis: o da filosofia da consciência ou do sujeito e o da comunicação, ou seja, o paradigma do conhecimento de objetos e o paradigma do entendimento entre sujeitos capazes de falar e agir. 0 que define cada um destes paradigmas é sua relação com o sujeito cognoscente. No paradigma da filosofia da consciência, que serviu de moldura a Descartes, Spinoza, Leibniz, Kant, Schelling e Hegel, o sujeito é interpretado basicamente como dotado de capacidade de assumir um duplo enfoque com relação ao mundo dos objetos possíveis: o conhecimento de objetos e a dominação. [...] No paradigma da comunicação proposto por ele o sujeito cognoscente não é mais definido exclusivamente como sendo aquele que se relaciona com objetos para conhecê-los ou para agir através deles e dominá-los. Mas como aquele que, durante seu processo de desenvolvimento histórico, é obrigado a entender-se junto com outros sujeitos sobre o que pode significar o fato de "conhecer objetos" ou "agir através de objetos", ou ainda "dominar objetos ou coisas". (SIEBENEICHLER, 1989; p.61-62)

A mudança de paradigma proposta pelo filósofo supõe não apenas a superação do raciocínio lógico ou do processo de interpretação do conhecimento no qual o sujeito conhece isoladamente, mas, principalmente em tomar as ações e os atos de fala como ponto de partida de extrema importância no interior das relações.

Habermas (2012a) questiona, então, o paradigma da filosofia da consciência e procura explicar a essência da racionalidade comunicativa, que não é mais a relação do sujeito isolado com algo no mundo objetivo, representável e manipulável; o que é paradigmático para o autor é, ao contrário, a relação intersubjetiva que se instaura entre os sujeitos capazes de falar e de agir, assim que eles se entendem entre si sobre alguma coisa.

Existem dois tipos de racionalidade que seguem direções distintas: a racionalidade técnico-instrumental, que define as ações do sujeito como relações de domínio sobre a natureza e os sujeitos; e a racionalidade comunicativa, que define as ações do sujeito como relações com outros sujeitos na busca de um entendimento consensual.

Para Habermas, a racionalidade técnico-instrumental ou razão instrumental caracteriza-se pelo distanciamento entre sujeito e objeto, um sujeito que busca uma operação lógica e metódica dos conhecimentos. Assim, é uma razão parcial e absoluta que reduz a riqueza dos fenômenos aos seus conceitos e regras, isto é, elimina da realidade aquilo que não se ajusta a seus princípios. A evolução do conhecimento e da aprendizagem fica refém de princípios universais tidos como imutáveis, não havendo espaços para questionamentos. No processo ensino-aprendizagem, considera o educando como um objeto; despreza seu potencial crítico e se limita a explorar seu caráter abstrato para concretizar uma razão individual e monológica. 0 grupo hegemônico aproveita esta visão parcial e unidimensional para reforçar suas ideias e impor a dominação e manipulação.

No entanto, Habermas busca uma alternativa para as sociedades modernas que utilizam uma racionalidade instrumental e inconsistente: a razão comunicativa. Esta, vivenciada nas práticas cotidianas como a busca de entendimento e consenso compartilhado com os outros sujeitos, seria uma opção assertiva para o êxito pessoal e social dos sujeitos.

Dessa forma, a racionalidade comunicativa baseia-se na compreensão e no aprendizado, o que permite a socialização e o livre reconhecimento dos objetos e fatos pelos sujeitos envolvidos. É uma razão que faz parte do mundo vivido, isto é, formado por símbolos que nascem das interações entre os sujeitos, transmitidos pelas gerações na atividade comunicacional. Portanto, a razão comunicativa propicia um autoconhecimento, fruto da liberdade e entendimento alcançados pelas condições de uma socialização comunicativa.

Para a viabilidade de uma ordem social é necessário que se estabeleçam certos padrões de interação que permitam um entrelaçamento regular e estável de ações. Para que isso ocorra, é necessário que as ações sejam coordenadas segundo regras, ou seja, que obedeçam a um mecanismo de coordenação (HABERMAS, 
2012b). E é exatamente sob o ponto de vista do mecanismo que é utilizado para a coordenação das ações particulares que os conceitos de ação social podem ser distinguidos.

Podem-se distinguir basicamente dois mecanismos de coordenação e, consequentemente, dois tipos de ação social ou de interação. A coordenação das ações conta ou "com um influxo empírico de ego sobre alter ou com o estabelecimento de um acordo racionalmente motivado entre ego e alter" (HABERMAS, 2012b). No primeiro caso tem-se uma interação de tipo estratégico; no segundo, uma interação de tipo comunicativo. Essas duas formas básicas de interação podem ser melhor explicitadas a partir do tipo de saber que nelas está encarnado e do diferente uso que é feito da linguagem.

Toda ação se baseia em um saber ou, dito de outro modo, toda ação é a manifestação de um saber ou de uma convicção. No caso de uma ação social, o que se manifesta pode ser tanto a expressão de um saber comum como também a expressão de uma imposição de uns sobre outros. As duas possibilidades demarcam o uso de distintos mecanismos de coordenação da ação.

Na orientação para o acordo, própria do agir comunicativo, pressupõe-se que os participantes da interação possam chegar a um saber comum. 0 que o autor chama de saber comum é "[...] um saber que funda acordo, sendo que tal acordo constitui o resultado de um reconhecimento intersubjetivo de pretensões de validez susceptíveis de crítica" (HABERMAS, 2012b, p.481). Nesse sentido, o acordo significa que os participantes aceitam um saber como válido, quer dizer, como intersubjetivamente vinculante.

Em outros termos, no agir comunicativo pressupõe-se que os participantes possam chegar, por manifestações de apoio ou de crítica, a um entendimento acerca do saber que deve ser considerado válido para o prosseguimento da interação. Nesse caso, as convicções intersubjetivamente compartilhadas constituem um potencial de razões que vinculam os sujeitos em termos de reciprocidade.

Já no mecanismo da influenciação recíproca, própria do agir estratégico, o ator não vê no companheiro da interação um sujeito com o qual é possível estabelecer um acordo intersubjetivo. Por isso, sua opção será a de agir sobre ele, de induzi-lo a aceitar uma convicção como válida, utilizando-se, num caso mais extremo, até de mentiras e de ameaças. 0 que lhe importa é a busca de êxito com relação aos fins que ele projeta sob o seu exclusivo ponto de vista. O outro, com seu plano de ação ou sua convicção, é visto como obstáculo ou como meio para a realização de seu próprio plano de ação. A interação que resulta desse influxo externo de uns sobre outros se assenta em convicções monológicas e por isso não consegue estabelecer o mesmo vínculo de reciprocidades que caracteriza a orientação para o acordo (HABERMAS, 2012b, p. 482).

Os mecanismos de coordenação das ações se distinguem ainda a partir de um distinto uso da linguagem. Toda ação social, como solução de um problema de coordenação, implica algum tipo de comunicação linguística ou, pelo menos, um intercâmbio de informações. Sem isso, obviamente nenhum tipo de entrelaçamento de ações particulares é possível. No mecanismo estratégico, a linguagem aparece tãosomente como meio de transmissão de informações, sendo que o efeito de coordenação ocorre por força de influências recíprocas em que os atores perseguem fins. Já no mecanismo comunicativo, a linguagem aparece como geradora de entendimento e fonte de integração social (HABERMAS, 2012a, p. 7l).

o que precisa ser destacado é que os dois mecanismos de coordenação acima referidos se excluem mutuamente, ao menos na perspectiva dos participantes, uma vez que "os processos de entendimento não podem empreender-se simultaneamente com a intenção de chegar a um acordo com um participante na interação e de exercer influência sobre ele, quer dizer, de realizar causalmente algo nele" (HABERMAS, 2012b, p. 482).

Um acordo depende de contextos de cooperação, uma vez que ele não pode ser imposto de fora ou ser forçado por uma das partes, seja por gratificação ou ameaça, sugestão ou engano. Predomina aqui o enfoque intersubjetivo, em que falantes e ouvintes buscam entender-se sobre determinada situação e a forma de dominá-la. Já no mecanismo da influenciação, o ator assume o enfoque objetivador, em que os outros aparecem como rivais ou entes manipuláveis. 0 potencial analítico das categorias de agir estratégico e de agir comunicativo fica mais evidente com a consideração do modelo de racionalidade que subjaz a cada um desses tipos de ação.

A teoria crítica da sociedade é entendida e subdividida por Habermas em dois mundos, quais sejam: o mundo do sistema e o mundo da vida. 0 mundo do sistema pode ser considerado como o mundo formal, das regras, das leis, das normas, ou seja, um mundo artificial criado pelo homem visando ao êxito e ao domínio sobre a natureza. É um mundo construído a partir de um determinado paradigma dominante em uma dada época, em que toda organização social, política, econômica e cultural está moldada a partir deste paradigma. Ele se reflete na organização da sociedade, na educação, na abordagem científica e na tentativa de controle do mundo da vida. 
Considera-se que o conceito de ação comunicativa não pode ser entendido sem o complemento necessário que Habermas denomina de mundo da vida. Em outras palavras, o mundo da vida é o saber de fundo comunicativamente estruturado, a partir do qual ordenamos nossos processos de entendimento e justificamos nossas ações.

O mundo da vida é o lugar das relações sociais espontâneas, das reais necessidades dos sujeitos, seus sentimentos e percepções, dos vínculos estabelecidos com seus semelhantes, um nicho pré-científico, intuitivo, não tematizado e inquestionável. Pode-se perceber que o mundo da vida é um conceito que faz parte e completa a ação comunicativa. É o espaço onde se constrói a razão comunicativa, a partir das relações intersubjetivas entre os sujeitos. [...] enquanto o falante e o ouvinte se entendem frontalmente acerca de algo num mundo, eles movem-se dentro do horizonte do seu mundo de vida comum e este continua a ser para os intervenientes como um pano de fundo intuitivamente conhecido, não problemático, indesmembrável e holístico (HABERMAS, 2012b; p.278).

Assim, é evidente que o mundo da vida fornece subsídios para se chegar a um entendimento na ação comunicativa, ou seja, seria uma base de sustentação para que ocorra uma verdadeira ação comunicativa entre os homens, que carregam toda uma tradição cultural, um saber implícito, pré-teórico, uma linguagem própria, um conhecimento tácito.

O mundo da vida proporciona um grande aprendizado, pois é por meio das interações que estabelecemos com outros sujeitos que iremos direcionar nossas ações de modo racional. Por interação, Habermas (1987) entende o locus da sociedade no qual as normas sociais se formam a partir da convivência entre sujeitos, pela comunicação e ação. Nessa dimensão da prática social prevalece a ação comunicativa e a socialização dos participantes do mundo da vida, que estão diretamente ligadas às condições materiais. 0 conceito de mundo da vida ou mundo vivido, para Habermas, envolve um contexto em que os sujeitos capazes de linguagem situam e datam seus pronunciamentos em espaços sociais e tempos históricos.

Ao elaborar a Teoria da Ação Comunicativa, Habermas parte de uma filosofia que trata do ser humano como sujeito dotado de linguagem, movido para a compreensão dos fatos. Pela comunicação, o sujeito se depara com as tradições culturais, com os ordenamentos sociais e com as estruturas de personalidade, elementos que se inter-relacionam de uma forma estreita.

0 entendimento do mundo expresso por Habermas leva a pensar a sociedade de forma mais ampla, articulada com a subjetividade dos sujeitos que dela partilham, numa relação dialética entre o sistema e o mundo da vida. As contradições vividas por esses dois mundos são apresentadas como condição de resistência dos sujeitos frente à desestruturação que o mundo do sistema pretende ao tentar controlar o mundo da vida, distanciando-se dele gerando insatisfações, miséria, submissão e violência. Pensar esses conflitos estabelecidos na sociedade remete a pensar a Educação e, mais especificamente a Educação Escolar, com vistas a compreendê-la nesse emaranhado de relações postas, quer no mundo da vida, quer no mundo do sistema.

Em relação ao agir comunicativo, Habermas (2012a) considera a linguagem como geradora de entendimento e fonte de integração social. Na perspectiva habermasiana a linguagem é entendida como ato de fala ou ação. Considerando os objetivos da pesquisa a segunda opção nos parece mais apropriada por se tratar de uma tentativa de compreender a racionalidade que orienta as práticas dos professores em situação de aula.

A linguagem torna-se, então, um diferencial na teoria de Habermas. Podemos considerá-la como toda e qualquer forma de comunicação que pode modificar o comportamento dos sujeitos. Na concepção habermasiana, a linguagem é concebida como o elo de interação entre os sujeitos, a fim de garantir a democracia das decisões coletivas por meio de argumentações. Dessa forma, é possível manter atos comunicativos utilizando contextos não verbais a partir da concepção habermasiana de linguagem? Neste caso, fala-se de outra forma de comunicação, que não seja feita nem por sinais verbais nem pela escrita, é a linguagem não verbal representada neste trabalho pela linguagem cartográfica. Sendo assim, o código a ser utilizado neste contexto é a simbologia que representa os elementos espaciais.

O conhecimento é construído a partir de um processo de interação e interesse regido por curiosidade epistemológica e rigor metodológico. Os processos pedagógicos envolvem as relações sociais e essas relações se dão em contextos comunicativos voltados ao entendimento que ocorrem no chão da sala de aula ou no espaço escolar. No caso da escola podemos representá-los por dois grupos sociais sendo eles: gestores (diretores, equipe pedagógica e gestão municipal) e os atores (professores, alunos e conselhos representativos). 
A educação é considerada, segundo Boufleuer (2001), como uma ação entre sujeitos, ou seja, uma ação social, pois toda ação social se dá a partir de uma interação entre os planos de ação de dois ou mais sujeitos, de forma que as ações de um possam ser conectadas às ações de outro.

Toda ação se baseia em um saber ou, se preferirmos, é a manifestação de um saber ou de uma convicção. No caso de uma ação social, o que se manifesta pode ser tanto a expressão de um saber comum como a expressão de uma imposição de uns sobre os outros. As duas possibilidades demarcam o uso de distintos mecanismos de coordenação de ação.

O que determina então a racionalidade de uma ação? Inicialmente seria importante esclarecer o que se entende por racionalidade. Boufleuer (2001) menciona que a primeira impressão é a de que racionalidade está no domínio do saber que a linguagem expressa, e a ação realiza. De fato, existe uma relação entre estes dois elementos, no entanto, Habermas (2012b) argumenta que a racionalidade de um ato de fala ou ação diz respeito nem tanto ao saber em si ou à sua aquisição, e sim à forma como os sujeitos capazes de linguagem e de ação fazem uso desse saber. Portanto, a racionalidade está na forma como os sujeitos fazem uso do saber encarnado em suas ações e manifestações simbólicas. Pode-se chamar então de racional o sujeito que é capaz de fundamentar a convicção que motiva sua ação ou sua fala. Na perspectiva da TAC, a racionalidade que orienta as ações de um sujeito pode ser do tipo instrumental, voltada ao êxito, ou do tipo comunicativa, voltada ao entendimento.

Figura 15 - Tipos de ação social em Habermas

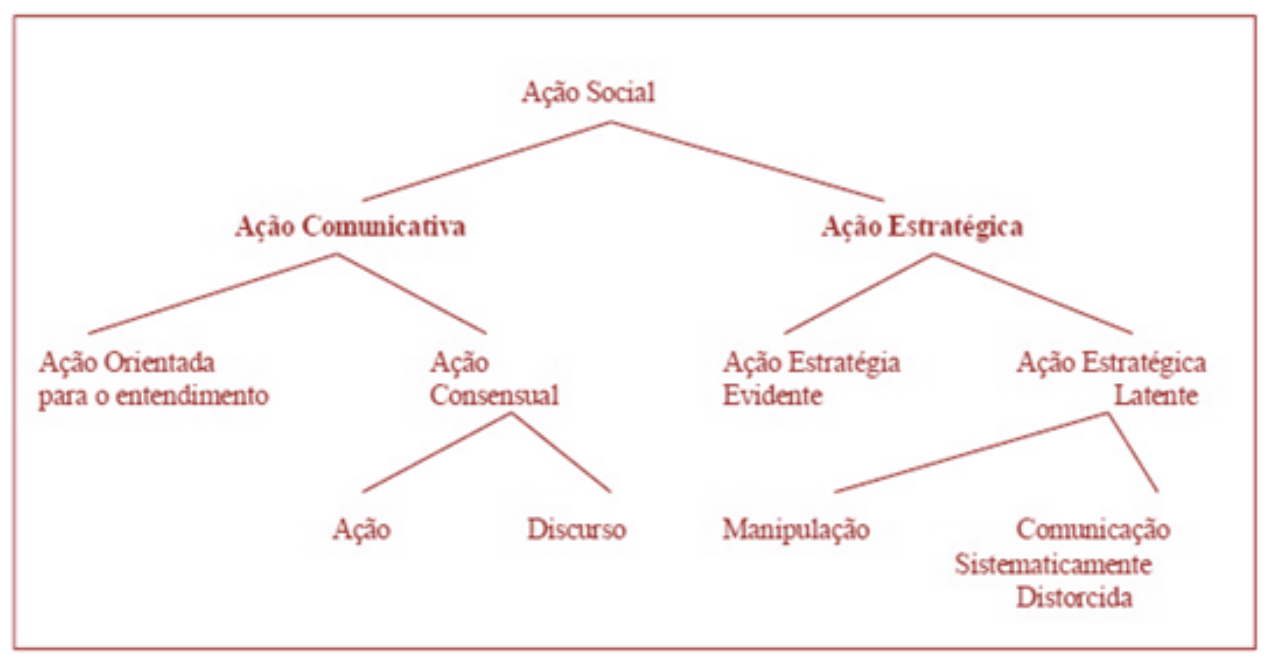

Fonte: Habermas (1996).

A reflexão do professor no que se refere a sua prática, tem que ter como foco principal as razões que fundamentam sua fala e sua ação. Em suma, o professor é um "ator racional" em dois sentidos: primeiro porque é capaz de agir, e de fato age a maior parte de seu tempo a partir de razões/racionalidades; segundo porque é capaz de refletir sobre essas razões/racionalidades para articulá-las, criá-las e reformulá-las. Portanto, a racionalidade, é uma capacidade essencial do professor enquanto ator envolvido na ação, "a capacidade de agir, de falar e de pensar, elaborando uma ordem de razão para orientar sua prática” (TARDIF; GAUTHIER, 2001, p.198). 


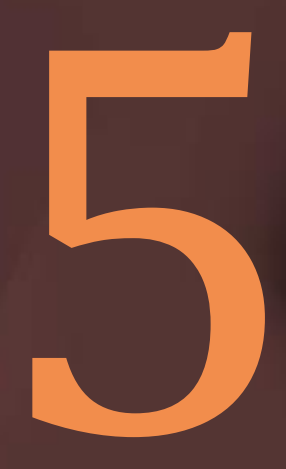

Saberes e racionalidades dos professores de geografia no chão da sala de aula 
0 atual contexto em que a educação nacional se encontra leva a crer que o grande desafio da gestão pedagógica da sala de aula, bem como da transformação pedagógica dos conteúdos de ensino, é a geração ou produção de saberes práticos frente aos novos desafios presentes no cotidiano da escola, capazes de orientar a tomada de decisão no chão da sala de aula ou em outros espaços educativos. Naturalmente, cabe a ao professor articular adequada e criativamente seu reservatório de saberes num determinado contexto de interação com outros sujeitos, no ambiente escolar ou em diferentes contextos de trabalho.

Nem mesmo os documentos oficiais, como a Lei de Diretrizes e Base (LDB), os PCN, os diversos pareceres e as resoluções do Conselho Nacional de Educação (CNE), bem como a nova Base Nacional Comum Curricular (BNCC), sejam eles relativos à formação de professores, sejam relativos às competências básicas das áreas específicas de ensino, têm dado conta de propor políticas educacionais capazes de minimizar as disparidades de níveis dos cursos de formação de professores no Brasil. Isso ocorre porque, geralmente, tais documentos esbarram em contradições e pontos indefinidos quando se trata da dimensão pedagógica da formação para a docência (THERRIEN, 2006).

Para o autor citado acima, a grande dificuldade do CNE reside não apenas na definição de diretrizes curriculares para os cursos de licenciatura, mas também na falta de consenso sobre os elementos estruturais do sistema de formação de professores e sobre as concepções pedagógicas fundantes da formação docente na sociedade contemporânea. Um reflexo da falta de resoluções que definam o currículo mínimo para os cursos de formação de professores é a existência de centenas de currículos com diferentes focos para a formação dos licenciados, a exemplo os cursos de Geografia. Sampaio (2013) aponta esse problema ao analisar currículo de universidades públicas e privadas no Brasil.

De certa forma, isso é ruim para os licenciados, pois, durante a formação inicial, considerado o primeiro contato com os saberes profissional e da disciplina uma vez que cada universidade tem um currículo diferente. Tardif (2014) destaca a existência de quatro tipos básicos de saberes presentes na atividade docente, sendo eles: os saberes da formação profissional adquiridos ao longo da trajetória de formação do professor, desde a formação inicial; os saberes disciplinares, que são os saberes relacionados aos conceitos específicos da área de formação; os saberes curriculares, referentes ao currículo adotado no sistema de ensino; e, por fim, os saberes experienciais, que são os saberes referentes ao fazer e ao ser professor adquiridos ao longo da trajetória prática.

Vale ressaltar que os saberes profissionais, disciplinares e curriculares são saberes pré-definidos pelos sistemas de ensino, ou pelas universidades. Nesse caso, o papel do professor do ensino fundamental é o de transmissor de um conhecimento já elaborado, ou seja, da tradição cultural, um dos componentes simbólicos do mundo da vida. Resta assim, o saber da experiência como um saber cumulativo e dinâmico, pois é em situação de aula que o professor cria, recria e amplia seu reservatório de saber, sendo o único saber capaz de dar significado aos conteúdos de ensino responsáveis pela mobilização das estruturas cognitivas dos estudantes. De posse desse saber, o professor é capaz de promover a transformação pedagógica dos conteúdos de ensino em situações que tenham significado para a vida dos estudantes.

0 desafio enfrentado pelo professor no cotidiano da escola frente ao saber a ser utilizado nas ações didáticas não são fáceis, pois trata-se de uma incerteza, não em relação ao conteúdo a ser ensinado e sim em relação a utilidade que esse conteúdo terá no cotidiano do aluno. Isso ocorre porque trata-se de um processo educativo e, nesse sentido, a educação é considerada por Boufleuer (2001) como uma relação social, no qual o mecanismo de coordenação das ações deve ser guiado por ações comunicativas.

O presente capítulo tem como objetivos caracterizar quem são os professores que ministram aulas de Geografia nos anos finais do ensino fundamental e como os mesmos utilizam a linguagem cartográfica ao trabalharem com os conteúdos escolares em sala de aula; compreender a racionalidade que orienta suas ações no chão da sala de aula e analisar, a partir do contato com os pressupostos da TAC, as práticas cotidianas dos professores no chão da escola. Nesta seção do trabalho, apresentam-se dados referente ao perfil dos professores que ministram aulas de Geografia seguindo a lógica dos saberes docentes (TARDIF, 2014). Em seguida, apresentam-se os resultados referentes aos planos de trabalho das escolas, na tentativa de compreender a racionalidade que orientou as práticas dos professores no chão da escola durante a realização do trabalho e, por fim, os desafios que os professores enfrentam diariamente no espaço das escolas.

\subsection{O PROFESSOR DE GEOGRAFIA E O SABER DA FORMAÇÃO PROFISSIONAL}

Nas instituições universitárias, templos da produção científica, a grande tradição de formação de cientistas bacharéis e de eminentes pesquisadores mantém consagrado o olhar científico de uma ciência 
predominantemente positiva e objetiva focada no produtivismo. Ao mesmo tempo, tem-se, de um lado, os formadores de professores para a educação básica, docentes universitários competentes nas suas áreas disciplinares específicas e nos seus laboratórios, grupos e/ou núcleos de pesquisa, que conduzem os processos formativos com o predomínio da racionalidade técnico-instrumental, alheios ao olhar pedagógico dos processos de ensino e de aprendizagem. Do outro lado, muitas vezes tem-se uma minoria nos cursos de licenciatura que demonstra uma preocupação com a formação de sujeitos autônomos guiados por uma racionalidade que, na maioria das vezes, não consegue conciliar harmoniosamente as dimensões de instrução e de formação do ato educativo, dicotomizando assim a formação para autonomia profissional e a formação para cidadania.

Isso tem ocorrido não só nas universidades que ofertam as duas modalidades de graduação em Geografia (bacharel e licenciatura), mas também naquelas IES que ofertam apenas a licenciatura. Sampaio et. al. (2005) identificam um grande número de professores com diferentes formações dando aulas de Cartografia nos cursos de Geografia. Os autores destacam principalmente a atuação desses profissionais em cursos de Geografia licenciatura. Vale ressaltar que, em algumas universidades, as disciplinas de Cartografia, Cartografia Temática, bem como as que compõem a área da chamada Geografia Física são consideradas comuns às duas modalidades de curso, com a mesma ementa, programa, carga horária e professor.

Para Tardif (2014), o saber profissional consiste em um conjunto de saberes baseados nas ciências e são transmitidos aos professores durante o processo de formação inicial e/ou continuada, especialmente durante a formação inicial, uma vez que a formação continuada não é garantida pelos sistemas de ensino, visto que, na maioria das vezes, os professores precisam retirar de seus rendimentos para pagar cursos de aperfeiçoamento ou especialização.

Também se constituem o conjunto dos saberes da formação profissional os conhecimentos pedagógicos relacionados às técnicas e métodos de ensino (saber-fazer), legitimados cientificamente e igualmente transmitidos aos professores ao longo do seu processo de formação nos cursos de formação de professores. (TARDIF, 2014, p.36)

No campo, procurou-se identificar a origem do saber profissional dos professores de geografia da rede pública municipal de Imperatriz-MA. Na tabela a seguir consta um demonstrativo do que foi encontrado nas escolas: apenas metade dos professores com formação inicial em Geografia, os demais com diferentes formações, porém ministrando aulas da disciplina. Se a principal fonte de aquisição desse saber é a universidade, durante o processo de formação inicial, cabe um questionamento quanto à racionalidade utilizada pelos professores que não possuem a formação inicial em Geografia e, mesmo assim, ministram aulas desse componente curricular.

Tabela 9 - Formação inicial dos professores

\begin{tabular}{|c|c|}
\hline Área de Formação & Quantidade \\
\hline Geografia Licenciatura & 17 \\
\hline Pedagogia Licenciatura & 08 \\
\hline História Licenciatura & 05 \\
\hline Administração Bacharelado & 01 \\
\hline Biologia Licenciatura & 01 \\
\hline Matemática Licenciatura & 01 \\
\hline Estudos Sociais Licenciatura Curta & 01 \\
\hline Total & 34 \\
\hline
\end{tabular}

Fonte: Trabalho de Campo

No tocante à formação inicial, merecem destaque os professores com formação em licenciatura em Pedagogia e História. Aos pedagogos são atribuídas as responsabilidades do ensino de Geografia no ensino fundamental anos iniciais, e não nos anos finais, como atestam os dados acima. Já quanto os formados em História, acredita-se que, durante a formação inicial, os mesmos têm um domínio dos conceitos e 
procedimentos da História, mas a relação que desenvolvem sobre o espaço/tempo em Geografia é diferente. Mesmo assim, para muitos, em especial os gestores educacionais, História e Geografia são "irmãs" e, por isso, podem ser ministradas pelo mesmo professor.

Foi possível identificar nas escolas selecionadas para a pesquisa cinco professores formados em Geografia, todos com curso de pós-graduação lato sensu em nível de especialização, porém nem todas são na área de ensino de Geografia. Além disso, há três professores formados em Pedagogia, sendo as duas pedagogas que participaram da pesquisa e um professor. Há ainda duas professoras formadas em História, sendo que uma não concluiu sua participação na pesquisa pelo fato de ter sido aprovada no mestrado em ensino de História na Universidade Federal do Tocantins, campus de Araguaína, além de uma professora formada em Administração de Empresas e com especialização na área da docência do ensino superior.

Durante a vivência nas escolas foi questionado junto à coordenação pedagógica o porquê de muitos professores estarem atuando em uma área diferente de sua formação inicial, mas não foi possível obter resposta. No entanto, a distribuição da carga horária é feita na escola pela equipe pedagógica e, segundo informações obtidas em duas das três escolas, é possível que o professor atue em sua área de formação, mas, para isso, o mesmo teria que completar sua carga horária de 16 horas/aulas semanais em duas escolas diferentes. Diante dessa situação, muitos professores optam por trabalhar com outros componentes curriculares a fim de completar sua carga horária em uma única escola ou até mesmo ministrar toda a carga horária de aulas em componentes diferentes de sua formação, em função de questões específicas do tipo: trabalhar em uma escola com melhor estrutura física, o fato de a escola estar localizada próximo a sua residência, o que significa uma economia com transporte e tempo.

Outro dado importante a ser destacado é o fato que alguns professores estarem fazendo uma segunda graduação. Dentre os professores que ministram aulas de Geografia foi possível encontrar alguns professores com mais de uma graduação (Tabela 6). Vale ressaltar que a segunda graduação foi feita após o início da carreira do magistério. Por que uma nova graduação? Duas explicações são plausíveis: a primeira que, em busca de aperfeiçoamento, em geral os professores fazem Pedagogia como segunda licenciatura; a segunda explicação seria a decisão por mudar de profissão, sendo que, nesse cenário, o curso de Direito é o mais escolhido pelos professores.

Tabela 10 - Professores com mais de uma graduação.

\begin{tabular}{|c|c|}
\hline Professores & Quantidade \\
\hline Com mais de uma Graduação & 6 \\
\hline Com uma graduação & 28 \\
\hline TOTAL & 34 \\
\hline
\end{tabular}

Fonte: Trabalho de Campo.

Dito isso, chama-se atenção para alguns detalhes presentes no processo de formação profissional dos professores. Um deles é que, ao consultar os documentos oficiais no tocante à formação de docentes, em geral usa-se o termo "formação inicial e continuada", como se as duas fizessem parte do mesmo processo formativo. Porém, na realidade não é bem assim que as coisas acontecem, pois, para dar continuidade ao processo formativo, o professor na maioria das vezes precisa pagar por um curso de pós-graduação lato sensu ou curso de aperfeiçoamento. 0 acesso à pós-graduação stricto sensu é mais difícil ainda, pois o município não concede a licença remunerada para que os docentes possam dar continuidade ao processo de formação.

Dos 34 professores que responderam o questionário, cinco têm apenas graduação, 26 têm especialização e três têm mestrado. Os dados indicam que, aos poucos, os professores estão se preocupando em verticalizar suas formações. É importante ressaltar que os professores que têm mestrado estão na faixa etária dos 30 aos 39 anos. Já os professores que têm apenas a graduação são aqueles que já estão à beira da aposentadoria, na faixa dos 50 aos 60 anos. 
Tabela 11 - Formação inicial e continuada

\begin{tabular}{|c|c|}
\hline Professores & Quantidade \\
\hline Graduação & 05 \\
\hline Especialização & 26 \\
\hline Mestrado & 03 \\
\hline TOTAL & 34 \\
\hline
\end{tabular}

Fonte: Trabalho de Campo.

Ao consultar os relatórios de prestação de contas na Secretaria Municipal de Educação de Imperatriz-MA foram encontrados menções a gastos com encontros de formação continuada de professores, o que na verdade consiste em encontros de formação pedagógica, pois o conceito de formação continuada é bem diferente. Entende-se que a formação continuada é a formação em exercício, em especial para os professores que atuam em áreas diferentes de sua formação inicial. Além disso, a formação continuada é um processo contínuo e não encontros isolados que tratam de temáticas distante da realidade presente no cotidiano da sala de aula ou da escola.

Com relação à participação em cursos de formação complementar, apenas cinco professores afirmam ter participado de um programa de formação continuada para docentes chamado ARCO - Aprendizagem Reconstrutiva do Conhecimento. 0 referido programa foi objeto de estudo na dissertação de mestrado em Educação de Santos (2007). No levantamento feito foi possível identificar cinco professores que participaram de formação continuada através do projeto ARCO e 29 que não participaram de cursos de formação continuada. Ao questionar a coordenação dos anos finais do ensino fundamental na Secretaria de Educação sobre a formação continuada de professores, foi informado que existem encontros de formação continuada pelo menos duas vezes ao ano, ou seja, para a Secretaria de Educação, os encontros pedagógicos são considerados como formação continuada.

\subsection{O PROFESSOR DE GEOGRAFIA E O SABER DA DISCIPLINA}

Na opinião de Tardif $(2014$, p. 36) os saberes disciplinares são os "[...] saberes reconhecidos e identificados como pertencentes aos diferentes campos do conhecimento (linguagem, ciências exatas, ciências humanas, ciências biológicas, etc.)". Esses saberes são produzidos e acumulados pela sociedade ao longo da história da humanidade, são administrados pela comunidade científica e o acesso a eles deve ser possibilitado por meio das instituições educacionais, que constituem na verdade nos saberes da tradição cultural. Em suma, esse saber é agregado ao reservatório de saber do professor desde a formação básica e acompanha a formação acadêmica e continuada.

No caso da Geografia, esse saber faz parte dos conceitos e categorias que orientam a forma de interpretar o espaço geográfico. Para Moreira (2008), a Geografia é uma forma de ler o mundo, portando ela possui uma linguagem, assim como a Cartografia, ou melhor, a linguagem cartográfica tem auxiliado na leitura do mundo feita pelos geógrafos e pelos sujeitos da aprendizagem, a saber: os alunos. Nesse sentido, Almeida (2010) esclarece que a construção da Cartografia Escolar (Cartografia aplicada ao ensino) é uma junção de diferentes áreas como: Educação, Cartografia e Geografia como já abordado no Capítulo 3. Nesse processo, o professor deve fazer uma aproximação dos saberes disciplinares para auxiliarem no trabalho em sala de aula em situação de ensino.

No campo, com o auxílio do questionário, procurou-se investigar a noção que os professores de Geografia tinham sobre a linguagem cartográfica. Todos os professores que responderam o questionário afirmam utilizar a linguagem cartográfica em sala de aula. Não se sabe ao certo a forma como utilizavam tal linguagem, tampouco o que os mesmos entendiam por linguagem cartográfica. Na verdade, tem-se um problema sério quando se trata de usar os termos como: linguagem cartográfica, Cartografia Escolar ou até mesmo Cartografia pois, na mente das pessoas vem primeiramente o mapa. No entanto, por Cartografia se refere aos elementos simbólicos utilizados para representar espaços, paisagens, objetos no mapa.

Durante a pesquisa, procurou-se identificar a noção que os professores tinham da Cartografia enquanto linguagem capaz facilitar o processo de transformação pedagógica dos conteúdos escolas em situações de 
aula. A seguir, apresentam-se as noções de alguns professores sobre a linguagem cartográfica. A pergunta foi a seguinte: você considera a Cartografia como uma linguagem?

Quadro 21 - Noção dos professores sobre linguagem cartográfica.

\begin{tabular}{|ll|} 
PeCFeEx2 & $\begin{array}{l}\text { Sim. Pois considero linguagem tudo aquilo que você pode usar para se comunicar, passar uma } \\
\text { informação a outro e a Cartografia é tudo isso. A linguagem é o começo do processo de ensino e } \\
\text { aprendizagem, sem ela os objetivos de aprendizagem não serão alcançados de forma alguma. }\end{array}$ \\
\cline { 2 - 2 } PeSFeIn1 & Sim. Um elemento primordial para a aprendizagem dos alunos. Acho essencial. \\
\hline PeSFeEx & $\begin{array}{l}\text { Sim, porque ela oferece ao aluno uma forma de ler o mapa, analisar e transcrever as informações } \\
\text { contidas no mapa. Me dando apoio para transmitir ao aluno o conteúdo mais preciso e facilitar a } \\
\text { aprendizagem do mesmo. }\end{array}$ \\
\hline
\end{tabular}

Fonte: Trabalho de Campo

Após compreender a noção que os professores tinham da Cartografia enquanto linguagem, procurou-se identificar quais os conteúdos cartográficos os docentes tinham dificuldades de trabalhar em sala de aula, seja pela falta de domínio dos conceitos específicos ou pela ausência de material de apoio didático. Dentre os conteúdos citados estão: escala, projeções cartográficas, coordenadas geográficas, além da leitura e interpretação de tabelas, gráficos e mapas. Retomando a discussão do Capítulo 2, ao falar da relação da Cartografia com o ensino de Geografia, Cavalcanti (2002) e Moreira (2014) chamam a atenção para a existência de duas geografias distintas, uma Geografia Teórica, construída no espaço acadêmico das universidades e faculdades, e uma Geografia Escolar ou Geografia dos professores. Moreira é mais categórico ao classificar cada tipo de Geografia em determinado momento da história da Geografia Brasileira. No geral, a Geografia Acadêmica foi e continua sendo totalmente diferente da Geografia Escolar.

Com relação aos recursos didáticos disponíveis nas escolas, os professores mencionaram a existência dos seguintes: mapas, em especial do Brasil, globo físico e político e acesso à internet, caso o professor queira utilizar mapas digitais. Algumas escolas dispõem de laboratório de informática e sala de mídia, outras não dispõem de recursos audiovisuais. Considera-se relevante para a discussão do presente capítulo a retomada de dois aspectos que são: a formação inicial dos professores e a jornada de trabalho a qual cada um está submetido semanalmente. Os professores sem a formação em Geografia afirmam não saber utilizar de forma didática alguns recursos didáticos presentes na escola, outros apontam que não existe material na escola ou se existe está em péssimas condições de uso ou em número insuficiente para o elevado número de alunos em classe, ou até mesmo a falta de espaço nas salas, ou falta de tempo para o planejamento de atividades dessa natureza.

Quadro 22 - A linguagem cartográfica e sua relação com os conteúdos de ensino

\begin{tabular}{|c|c|}
\hline PeCFeEx2 & $\begin{array}{l}\text { Sim, utilizo com frequência. Vale ressaltar que o aluno ainda apresenta muita dificuldade, pois não } \\
\text { está sendo trabalhada direito nos anos iniciais e o aluno, ao adentrar nos anos finais, traz muitas } \\
\text { dificuldades e o trabalho é o de alfabetizá-lo, iniciação aos elementos da Cartografia, criando um } \\
\text { déficit considerável nessa área, principalmente nas turmas de oitavos e nonos anos. Com relação } \\
\text { ao trabalho com mapas, encontro alunos que não sabem ler uma legenda, uma escala, não } \\
\text { compreendem que todo mapa possui um título e que o mesmo traz consigo temáticas a serem } \\
\text { discutidas e analisadas. Encontrei uma aluna, esse ano (2016), que não sabia distinguir o mapa de } \\
\text { vegetação do mapa de bacias hidrográficas do Brasil. Compreendi que a mesma não tinha a } \\
\text { obrigação de entender os contornos de outro país, mas que os contornos e o desenho do mapa do } \\
\text { Brasil a mesma já deveria ter adquirido essa competência. }\end{array}$ \\
\hline PeSFeIn2 & $\begin{array}{l}\text { Não costumo utilizar com muita frequência, pois encontro dificuldade por não ser da área de } \\
\text { Geografia. Os conteúdos que mais tenho dificuldade, quase todos, eu uso mais os mapas de } \\
\text { continentes, países e regiões; fica mais fácil o aluno entender olhando para o mapa. }\end{array}$ \\
\hline
\end{tabular}

Fonte: Trabalho de Campo

Em parágrafos anteriores, foram apresentados alguns dados referentes às dificuldades que os professores enfrentam ao trabalharem com conteúdo de Cartografia nas aulas de Geografia. Dentre eles, foram citados 
conceitos específicos da Cartografia. Durante a realização das entrevistas, essa pergunta foi feita com o objetivo de fazer uma conexão entre as dificuldades conceituais citadas pelos professores e as condições estruturais que as escolas ofereciam para a realização de atividades que envolvessem o uso da linguagem cartográfica no chão da sala de aula. Em geral, nas escolas localizadas no centro da cidade não existem espaços destinados à realização de atividades desta natureza; todas as atividades são desenvolvidas em sala de aula. Já nas escolas localizadas nos bairros, que, em geral, foram construídas mais recentemente, apresentam uma melhor estrutura, com salas amplas, mais arejadas, laboratórios, salas de mídia.

A grande quantidade de alunos por turma e a falta de espaço apropriado para o desenvolvimento de atividades com mapas, desenhos, leitura de cartas e até mesmo a ausência de material didático constitui uma limitação presente na fala dos professores entrevistados. Diante desse quadro, é possível afirmar que a maioria dos professores é levada a tomar decisões didáticas guiada por uma racionalidade técnicoinstrumental, pensando às vezes mais na facilidade do trabalho docente do que na aprendizagem dos alunos.

Quadro 23 - Dificuldades relatadas pelos professores no desenvolvimento de atividades em sala de aula.

PeSFeEx

PeCFeIn1
Acho que a palavra que resume tudo isso seria FALTA, pois falta a preparação teórica do professor, falta o envolvimento dos alunos, pois a maioria não sabe nem ler e escrever, além da falta de material para o desenvolvimento das atividades.

Uma das principais dificuldades e limitações na utilização da linguagem cartográfica está principalmente na falta de uma base sólida nas séries inicias de ensino dos alunos e consequentemente a falta de habitualidade com essa linguagem.

Trabalho de Campo

Destaca-se a importância de focalizar não somente a ação dos professores no chão da sala de aula, mas também o contexto sociocultural e político no qual a prática educativa se insere, bem como as subjetividades dos sujeitos da pesquisa. A realidade encontrada nas escolas de Imperatriz-MA não difere muito da realidade de outras cidades, municípios e estados brasileiros e, assim como o professor opta pelo trabalho que facilita sua prática em detrimento da aprendizagem dos alunos, os responsáveis pela gestão do ensino, sem em qual nível for, optam também por redução de gastos, contratação de mão-de-obra sem a qualificação adequada bem como não investir na formação do quadro docente.

\subsection{PROFESSOR DE GEOGRAFIA E O SABER CURRICULAR}

Na concepção de Tardif (2004, p. 38), os saberes curriculares são na verdade um "[...] conjunto de conhecimentos relacionados à forma de como as instituições educacionais fazem a gestão dos conhecimentos socialmente produzidos e que devem ser transmitidos aos estudantes (saberes disciplinares)". Esse saber apresenta-se concretamente sob a forma de programas de ensino na forma de objetivos, conteúdos e propostas metodológicas que os professores devem aprender e aplicar no chão da sala de aula. Numa perspectiva da TAC, pode-se chamar de saberes responsáveis pela reprodução da tradição cultural, um dos componentes simbólicos do mundo da vida.

Historicamente, os currículos escolares foram estabelecidos pelos sistemas de ensino. A partir da LBD, os PCN constituem um exemplo de sugestão curricular para o sistema educacional brasileiro, tanto para escolas quanto para as editoras que elaboram o livro didático. Mas há de se levar em consideração que a referida sugestão curricular tem alguns pontos controversos, como a divisão do ensino fundamental em duas etapas e cada etapa divididas em ciclos, que não dialogam uns com os outros, bem como a primeira etapa do ensino fundamental não dialoga com a segunda, seja pelo fato de os pedagogos estarem responsáveis pelo processo formativo na etapa inicial e o geógrafo licenciado responsável pela formação na segunda etapa. Inúmeros trabalhos têm sido escritos e publicados por geógrafos insatisfeitos com o processo de formação no ensino fundamental nos anos iniciais.

A situação no Maranhão, bem como na cidade de Imperatriz não é diferente. Como já relatado no Capítulo 3, o impasse existente entre a SEDUC e a SEMED acarretou na ausência de um currículo de Geografia, bem de outros componentes curriculares do ensino fundamental anos finais. Durante a investigação em campo foi perguntado aos professores se os mesmos usavam o Referencial Curricular de Geografia elaborado e publicado pela SEDUC para planejar as atividades docentes. Do universo de 34 professores, 26 afirmam 
usar o RCGEF no ato do planejamento, enquanto oito afirmam não utilizar nem PCN nem RCGEF, usavam apenas o livro didático.

Algo que chamou a atenção durante o trabalho em campo foi a frequência em que ocorrem as reuniões para o planejamento de ensino nas escolas. No calendário letivo existem dias específicos para que o planejamento bimestral ocorra em todas as escolas municipais da cidade (zona urbana) e algumas escolas reservam também um dia específico para o planejamento mensal. Na tabela a seguir esses dados estão melhor representados de acordo com as informações coletadas na SEMED e nas secretarias das escolas.

Tabela 12 - Regime de Trabalho dos Professores

\begin{tabular}{|c|c|}
\hline Planejamento & Quantidade \\
\hline Mensal & 16 \\
\hline Bimestral & 14 \\
\hline Semestral & 4 \\
\hline Total & 34 \\
\hline
\end{tabular}

Fonte: Trabalho de campo

O planejamento de ensino é realizado nas escolas obedecendo duas modalidades, sendo o planejamento bimestral realizado coletivamente em um dia letivo, geralmente às sextas-feiras, e o planejamento mensal, que pode ser realizado individualmente caso haja necessidade de ajustes no plano bimestral. É comum entre os professores o uso do caderno de planejamento, onde constam os planos de aulas e anotações feitas sobre as mesmas.

Ao longo da pesquisa, foi possível participar de duas reuniões de planejamento: o planejamento anual, em janeiro de 2016, e o planejamento bimestral, em maio de 2016. Apenas uma escola disponibilizou a matriz do currículo para os professores elaborarem seus planos de ensino, nas demais, cada professor seguia sua própria orientação curricular na elaboração do plano de ensino, o que resultava na grande maioria copiar as orientações contidas no anexo dos livros didáticos.

Entre os professores que fizeram parte da amostra pesquisada, apenas um utiliza o currículo definido pela escola, três não utilizam nenhum tipo de orientação curricular e afirmam utilizar apenas o livro didático, e quatro utilizam o Referencial Curricular de Geografia do Ensino Fundamental elaborado pela SEDUC-MA em 2010. Dentre os que não utilizam o currículo defino pelo estado do Maranhão encontra um professor iniciante e sem formação em Geografia que afirma que "não existe currículo definido, costumo seguir apenas as orientações do livro didático" (PeSFeIn2). Dentre os que seguem o currículo e buscam outras orientações tem-se um professor com formação em Geografia e com mais de dez anos de experiência em sala de aula que diz: "Sim utilizo o currículo do estado e busco sempre autores da Geografia, com diferentes abordagens, como também utilizo os livros paradidáticos que existem na biblioteca da escola que são muito ricos" (PeCFeEx2).

A forma como a escola está organizada diz muito sobre a prática pedagógica dos professores. Das cinco escolas pesquisadas apenas duas possuem biblioteca funcionando e com um excelente acervo de livros didáticos, paradidáticos, atlas, vídeos e outros recursos. Em outras, o espaço reservado para a biblioteca serve de depósito para livros e outros materiais. 
Quadro 24 - Livros didáticos utilizados nas escolas.

\begin{tabular}{|l|c|c|}
\multicolumn{1}{|c|}{ COLEÇÕES } & EDITORAS & QUANTIDADE \\
\hline Projeto Araribá & Moderna & 16 \\
\hline Expedições Geográficas & Moderna & 9 \\
\hline Geografia e Participação & IBEP & 5 \\
\hline Geografia: Estudos para compreensão do espaço & FTD & 4 \\
\hline \multicolumn{2}{|c|}{ TOTAL } & 34 \\
\hline
\end{tabular}

Fonte: Trabalho de Campo.

Embora os 34 professores tenham afirmado usar a linguagem cartográfica em sala de aula, alguns afirmaram ter certas limitações, seja por falta de conhecimento teórico sobre os conceitos cartográficos, seja pela falta de recursos didáticos nas escolas.

Sobre o livro didático, consideram-se dois aspectos importantes que são: o processo de escolha do material e o uso no cotidiano da sala de aula. Em relação ao processo de escolha, a Secretaria Municipal realiza reuniões por área para a definição, obedecendo uma lista tríplice com três opções de obras. Em 2016, foi possível participar de duas reuniões de área. Nessas reuniões, cada escola envia um representante com a lista de obras escolhidas seguida de uma justificativa e define-se a lista tríplice. Nas áreas de Ciências e Matemática não houve debates sobre a escolha, pois a maioria das escolas tinham as mesmas obras selecionadas; apenas Língua Portuguesa, Geografia e História tiveram divergências nas obras definidas.

No início da reunião para aprovação das escolhas de livros feitas nas escolas de bairros, as falas dos representantes das unidades são prolongadas e, à medida que o tempo passa, as falas vão diminuindo pelo avançar do horário ou pelo fato de alguns estarem repetindo o que já foi dito por outros e as decisões tomadas seguindo uma racionalidade instrumental, pois grande parte dos representantes escolares são pedagogos e afirmam não terem argumentos suficientes para defender obras na área de Língua Portuguesa ou História e Geografia, por exemplo. Assim, a tendência é que concordem com as decisões dos demais.

Ao indagar sobre a participação no processo de escolha do livro didático, somente os professores que trabalham com Geografia há mais de cinco anos afirmaram ter participado do processo de escolha no quadriênio 2013-2015 e, dentre esses, apenas um explica de forma detalhada os critérios utilizados no processo de escolha do livro. Diante do exposto, é valido fazer alguns apontamentos. Em primeiro lugar, não é justo cobrar um ensino de qualidade de professores sem formação em Geografia que, sem opção, aceitam trabalhar com a disciplina para completar carga horária. A ausência de um currículo escolar leva os professores a trabalharem orientados pelo sumário do livro didático, cuja escolha não tiveram a oportunidade de participar democraticamente. Diante de todos esses problemas, que racionalidade pedagógica é possível de ser utilizada em situações de aula?

Quadro 25 - Livro didático: processo de escola e uso no cotidiano da sala de aula.

\begin{tabular}{|l|l|} 
& $\begin{array}{l}\text { Participei da escolha e analisei as obras com base em dois critérios de eliminação. 1o critério: } \\
\text { todas as coleções estavam de acordo com os objetivos do PNLD; } 2^{\circ} \text { critério: as coleções que } \\
\text { passaram na primeira etapa de análise se encontravam de acordo com os referencias } \\
\text { metodológicos da Geografia? Como se encontrava a estrutura dessas coleções? As mesmas } \\
\text { possuem uma apresentação, uma linguagem coerente a cada ano/série e uma proposta } \\
\text { metodológica coerente com a corrente filosófica e curricular? }\end{array}$ \\
\hline PeCFeEx2. & $\begin{array}{l}\text { Como eu costumo utilizar o livro em sala. Bem, meus alunos são da periferia de Imperatriz, muitos } \\
\text { deles possuem o livro didático como única fonte de consulta, por esse motivo o mesmo é utilizado } \\
\text { com frequência nas aulas e também para as tarefas de casa. Utilizo também outros livros de apoio } \\
\text { para que o aluno confronte as ideias abordadas no seu livro didático com ideias de outros autores. }\end{array}$ \\
\hline
\end{tabular}

Fonte: Trabalho de Campo. 
E como se dá o uso do livro didático no cotidiano da sala de aula? Em geral utiliza-se o livro didático diariamente em sala de aula, para leitura, análise de imagens, mapas e etc. A leitura, interpretação e a construção de mapas são processos inter-relacionados e imprescindíveis na aprendizagem da linguagem cartográfica na escola. Nesse pensar, o aluno participa ativa e conscientemente da produção de representações do espaço real como maquetes, croquis e mapas mentais, em constante diálogo com seus professores e colegas que, por sua vez, também são leitores e produtores ao mesmo tempo.

Portanto, para concretizar esse processo de educação cartográfica, é preciso saber como o aluno constrói a sua ideia sobre o espaço, em especial o espaço vivido. Para isso, o professor necessita agir pedagogicamente guiado por uma racionalidade que permita encarrar o trabalho na sala de aula como um processo em que cada aula constitui um passo a ser dado rumo à conquista de uma autonomia/emancipação na forma de pensar, falar e agir. 0 planejamento das atividades precisa ultrapassar as barreiras muitas vezes impostas pelo sistema escolar, como a sequência didática de conteúdos para cada bimestre que, na maioria das vezes, obedece ao sumário do livro didático; avaliação qualitativa e quantitativa que, quase sempre acaba resumindo tudo em números, fugindo totalmente do caráter qualitativo, em especial quando se refere às atividades cotidianas desenvolvidas em sala de aula ou em casa.

A ideia de avaliação qualitativa usualmente utilizada nas cadernetas dos professores da rede municipal da cidade de Imperatriz precisa ser interpretada de forma diferente. À luz da TAC, o qualitativo não significa apenas o cumprimento de um ritual, se o aluno fez ou não fez a atividade (tarefa), mas como fez e se é possível refazer sozinho ou com auxílio de um colega, ou até mesmo do professor. 0 refazer, nesse sentido, dá ao aluno uma nova oportunidade de pensar o processo de construção do conhecimento com vista à uma emancipação no processo de ver (percepção), internalizar (cognição) e expressar (representação) a leitura do mundo a partir da linguagem, seja ela escrita, falada ou representada graficamente.

\subsection{O PROFESSOR DE GEOGRAFIA E O SABER DA EXPERIÊNCIA}

Grande parte dos professores estão na faixa etária entre 30 e 50 anos de idade, no entanto, foi possível observar nas escolas muitos professores exercendo função de secretários pois, por problemas de saúde se afastaram da sala de aula e passaram a desenvolverem outras funções. Isso que parece um agravante, visto que, se o problema de saúde tiver sido adquirido em sala de aula, o correto seria o professor buscar tratamento e se ausentar da sala de aula, mas o que acontece é o desvio de função, e o problema de saúde continua.

Tabela 13 - Faixa Etária dos Professores

\begin{tabular}{|c|c|}
\hline \multicolumn{1}{|c|}{ Faixa Etária } & Quantidade \\
\hline Entre 20 e 29 anos & 5 \\
\hline Entre 30 e 39 anos & 11 \\
\hline Entre 40 e 49 anos & 10 \\
\hline Entre 50 e 60 anos & 7 \\
\hline Mais de 60 anos & 1 \\
\hline Total & 34 \\
\hline
\end{tabular}

Fonte: Trabalho de Campo.

No tocante à atuação profissional dos professores que ministram aulas de Geografia, tem-se as seguintes informações expressas nas tabelas abaixo. A maioria dos professores tem mais de dez anos de experiência, porém quando se investigou o tempo de serviço como professor de Geografia, o cenário. 
Tabela 14 - Tempo de serviço na educação básica

\begin{tabular}{|c|c|}
\hline Tempo de Serviço & Quantidade \\
\hline Menos de 5 anos & 9 \\
\hline De 5 a 10 anos & 4 \\
\hline Mais de 10 anos & 21 \\
\hline TOTAL & 34 \\
\hline
\end{tabular}

Fonte: Trabalho de Campo.

Dos 34 professores pesquisados, 18 têm menos de cinco anos ministrando aulas de Geografia do 6o ao 9o ano, não por serem recém nomeados, mas porque a maioria está ministrando aulas em diferentes disciplinas. Essa prática é comum no município de Imperatriz e, na zona rural, acredita-se que a realidade seja ainda pior.

Tabela 15 - Tempo de Serviço Como Professor de Geografia

\begin{tabular}{|c|c|}
\hline Tempo de Serviço & Quantidade \\
\hline Menos de 5 anos & 18 \\
\hline De 5 a 10 anos & 5 \\
\hline Mais de 10 anos & 11 \\
\hline TOTAL & 34 \\
\hline
\end{tabular}

Fonte: Trabalho de Campo.

Fazendo um comparativo entre as tabelas 09 e 10, observa-se que a maioria dos professores tem mais de dez anos de experiência como docentes da educação básica, porém menos de cinco anos como professores de Geografia. Isso pode ser atribuído a dois fatores: primeiro, à presença de professores sem formação específica em Geografia atuando na área e; segundo, pelo fato de boa parte dos professores terem feito graduação em Geografia ou outras áreas depois de concursados no município.

Para atender a exigências do MEC, os municípios firmaram convênio com a Universidade Estadual do Maranhão para capacitação dos professores. Dois programas foram criados com esse objetivo: o PROCAD (Programa de Capacitação Docente) e o PQD (Programa de Qualificação Docente). 0 primeiro era destinado a professores em exercício que não possuíam licenciatura e o segundo para professores e demais funcionários do município.

Tabela 16 - Jornada de Trabalho dos Professores

\begin{tabular}{|c|c|}
\hline Jornada de Trabalho & Quantidade \\
\hline 1 Turno & 6 \\
\hline 2 Turnos & 23 \\
\hline 3 Turnos & 5 \\
\hline TOTAL & 34 \\
\hline
\end{tabular}

Fonte: Trabalho de Campo.

Na nota técnica do INEP sobre o esforço docente, é utilizada uma escala de um a seis. A maioria dos professores se encontra entre as notas cinco e seis, ou seja, precisa trabalhar de dois ou três turnos para aumentarem a renda familiar, pois o município não paga o valor do piso salarial sugerido pelo MEC. Como lidar com a rotina da sala de aula frente a diferentes realidades, pois cada aluno compreende uma realidade distinta e precisa ser compreendida na sua individualidade, no entanto existem fatores que não 
colaboram para que esta compreensão aconteça? No quadro a seguir apresentam-se os depoimentos de alguns professores sobre a gestão pedagógica da sala de aula.

\section{Quadro 26 - A Gestão Pedagógica da Sala de Aula.}

\begin{tabular}{|ll} 
& $\begin{array}{l}\text { São situações de dificuldades que encontramos no dia-a-dia, em algumas salas de aulas e em outras } \\
\text { não. Tem turma que tudo que você planejar dá certo. E outro nada funciona. E no momento de } \\
\text { planejar uma aula, ou uma atividade, projeto, trabalho em grupo, temos que levar em conta a turma } \\
\text { e o horário que vamos trabalhar nesta turma. E se são dois ou um horário. Portanto, algumas vezes } \\
\text { fiquei muito triste, por não consegui fazer uma atividade da mesma forma e com entusiasmo em } \\
\text { turmas diferentes. Acreditava que era a minha falta de capacidade de envolver o aluno com o } \\
\text { conteúdo. Hoje, não fico triste, procuro reorganizar o que foi positivo e negativo para trabalhar } \\
\text { novamente o conteúdo. }\end{array}$ \\
PeSFeIn2 & $\begin{array}{l}\text { Nos dias de } 1 \text { aula ou só explicação ou resolução de atividades da aula anterior. O dia de } 2 \text { horários, } \\
\text { aula explicativa e atividades. }\end{array}$ \\
\hline PeSFeEx & $\begin{array}{l}\text { Nas turmas de } 2 / 1 \text { eu seleciono os conteúdos e faço a introdução e depois faz-se um debate e uma } \\
\text { explicação dos conteúdos e os horários } 1 / 1 \text { para resolver atividades. Já nas turmas } 1 / 1 / 1 \text { usa-se a } \\
\text { exposição e explicação pois a turma é mais fraca. }\end{array}$ \\
\hline
\end{tabular}

Fonte: Trabalho de Campo.

Um dos desafios enfrentados pelos professores diz respeito à quantidade de aulas de Geografia por semana: são três aulas, e nem sempre é possível a realização de duas aulas seguidas. As aulas têm duração de 50 minutos e, em geral, quando o professor tem apenas uma aula na turma, gasta em média 15 minutos para fazer a chamada e organizar a classe para poder iniciar a aula, tempo insuficiente para criar uma atmosfera favorável. Já quando tem as duas aulas seguidas, fica mais fácil de organizar atividades mais dinâmicas e criativas, segundo os professores. Os números 2/1 e 1/1/1 representam a forma de distribuição das aulas no horário: como dito anteriormente, são três aulas semanais e, em algumas escolas, foram distribuídas em duas aulas em um dia e uma aula em outro dia. Já na maioria das escolas a distribuição é de uma aula em cada dia.

Quadro 27 - Condições de trabalho e apoio pedagógico na escola

\begin{tabular}{|l|l|} 
PeCFeIn2 & $\begin{array}{l}\text { O espaço físico da sala de aula se torna ruim pela grande quantidade de alunos em sala. Às vezes } \\
\text { não dá para organizar a turma como gostaríamos. O trabalho do professor se torna mais difícil em } \\
\text { todos os aspectos com uma turma grande, como o número de atividades, a indisciplina, a realização } \\
\text { de trabalho de grupo. E no momento da correção dos cadernos de atividades também é um } \\
\text { problema pela grande quantidade. }\end{array}$ \\
$\begin{array}{l}\text { O espaço físico da escola é muito bom, o que está prejudicando muito a aprendizagem são as altas } \\
\text { temperaturas na cidade de Imperatriz, tendo em vista que a nossa escola NÃO conta com um } \\
\text { ambiente refrigerado, temos só ventiladores nas salas que no período da tarde fornecem um vento } \\
\text { muito quente e baixa umidade relativa do ar. Alguns professores, inclusive eu cheguei a passar mal } \\
\text { com o calor. Nos meses de agosto a outubro a dificuldade cresce por causa do período seco, já } \\
\text { presenciei alunos a passarem mal na sala (dores de cabeça e vômitos). O rendimento do aluno cai } \\
\text { durante esse período. Sinto uma queda brusca em todo o processo de ensino e aprendizagem, } \\
\text { nesse período. A quantidade de alunos nas salas ainda é grande. Para um trabalho satisfatório o } \\
\text { ideal seria } 25 \text { alunos por sala. }\end{array}$ \\
\hline
\end{tabular}

Fonte: Trabalho de Campo.

São os saberes da experiência que a maioria dos professores utilizam no cotidiano da sala de aula. Tardif (2014) considera saberes da experiência os que resultam do próprio exercício da atividade profissional dos professores. Esses saberes são produzidos pelos docentes por meio da vivência de situações específicas relacionadas ao espaço da escola e às relações estabelecidas com alunos e com seus pares. Nesse sentido, "incorporam-se à experiência individual e coletiva sob a forma de habitus e de habilidades, de saber-fazer e de saber ser" (p. 38).

E de que forma ocorre a relação dialógica entre esses saberes no chão da sala de aula em situações reais? Por mais que Tardif (2014) tente especificar que os saberes docentes podem ser provenientes do 
conhecimento a respeito das ciências da educação e de métodos e técnicas pedagógicas (saberes da formação profissional), do domínio do conhecimento específico a ser ensinado de acordo com a área de atuação de cada professor (saberes disciplinares), da apropriação de uma forma "escolar" de tratar os conhecimentos que serão objeto de ensino (saberes curriculares), ou da própria vivência diária da tarefa de ensinar (saberes experienciais), ao mesmo tempo ele reconhece que existe um saber específico que é o resultado da junção de todos esses saberes citados e que se fundamenta e se legitima no fazer cotidiano da profissão.

Dois pontos são importantes na análise da relação entre os saberes docentes apontados por Tardif e a dinâmica da escola. 0 primeiro ponto diz respeito ao local de aquisição do saber por parte do professor e o segundo é a forma de integração dos saberes já mencionados no parágrafo anterior com a realidade cotidiana da escola. Em relação ao lugar de aquisição dos saberes profissionais dos docentes, o autor se preocupa em evidenciar que o processo de constituição desse profissional não se restringe ao presente. Isso significa aceitar que as fontes de aquisição dos saberes dos professores se referem igualmente às experiências do presente e às do passado e que conhecimentos adquiridos no contexto da sua vida pessoal e familiar, assim como em toda a sua trajetória escolar, são decisivos também na constituição de sua identidade profissional, justificando, portanto, a característica temporal dos saberes dos professores. À luz da TAC, isso se refere à formação da personalidade, um dos componentes simbólicos do mundo da vida.

Outro aspecto importante a ser considerado é que o modo de integração dos saberes já citados à prática profissional dos docentes, em geral, acontece por processos de socialização. Seja pelas experiências de socialização pré-profissional (que antecedem o ingresso do professor na carreira) ou de socialização profissional (que se referem à trajetória profissional do professor), os saberes dos professores não são saberes caracterizados unicamente por uma construção individual. Por mais que se considere que o professor age sozinho, as relações estabelecidas ao longo de sua vida, na família, na escola e em outros espaços de convivência social, bem como a interação estabelecida com alunos, colegas de profissão e nas instituições de formação, interferem na tomada de decisões a respeito de suas ações didáticas. Os saberes profissionais, para Tardif, têm, portanto, origens diversas e só podem ser compreendidos se considerados em todos os seus aspectos.

\subsection{DIAGNÓSTICO DAS ESCOLAS, ELABORAÇÃO E EXECUÇÃO DO PLANO DE AÇÃO}

Ao chegar às escolas, uma das primeiras atividades que foram desenvolvidas foi a aplicação de um questionário (Anexo 3 ou 4), com o objetivo de traçar o perfil dos alunos do 6o ao 9o ano. Foi utilizado o mesmo questionário para todas as escolas. Após a aplicação e tabulação dos resultados, os dados foram comparados entre as escolas. Os resultados apontam para um perfil semelhante entre as escolas. Dentre as características encontradas estão: grande quantidade de alunos filhos de pais separados, elevado número de alunos repetentes, moram com familiares em locais que não possuem um espaço adequado para estudar ou fazer atividades da escola.

Observou-se também que muitos alunos moram perto da escola e que fazem o trajeto entre suas casas e a escola a pé ou de bicicleta. Foram sugeridas algumas atividades para que os professores fizessem com os alunos a fim de verificar a percepção dos estudantes sobre o espaço no entorno da escola. Ao longo do semestre 2016.1 foram realizadas visitas constantes às escolas e conversas com os professores, com a intenção de elaborar um plano de ação a ser desenvolvido no segundo semestre de 2016. Segue o quadro com a relação das escolas e planos de ação desenvolvidos.

Quadro 28 - Atividades do Plano de Ação das Escolas

\begin{tabular}{|c|c|c|}
\hline № & Escola & Plano de Ação \\
\hline 1 & Escola Municipal Paulo Freire & Feira de Ciências: Riacho bacurí \\
\hline 2 & Escola Municipal Frei Tadeu & Mostra de Ciências: relevo \\
\hline 3 & Escola Municipal Madalena de Canossa & Feira das Nações: África \\
\hline 4 & Escola Municipal Giovanni Zanni & Feira de Ciências: Alimentação \\
\hline 5 & Escola Municipal Wady Fiquene & Atividade: Movimentos Migratórios \\
\hline
\end{tabular}


As atividades do plano de ação foram determinadas de acordo com o calendário de cada escola, ficando a critério do professor escolher a temática a ser trabalhada e a maneira de desenvolver a atividade, lembrando apenas de utilizar os pressupostos da TAC no decorrer do processo. Foi notório o envolvimento maior ou menor de cada professor, além da relevância de fatores como o tempo de serviço na escola, a facilidade de comunicação com os pares e, lógico, o envolvimento com os alunos.

\subsection{AVALIAÇÃO DO PLANO DE AÇÃo}

É comum que, no segundo semestre, as escolas municipais realizem diferentes atividades científicas e culturais como forma de integração entre os estudantes e comunidade, bem como para divulgar parte do trabalho desenvolvido ao longo do ano letivo. As atividades do plano de ação foram desenvolvidas obedecendo ao calendário das escolas com um diferencial que foi a utilização dos pressupostos da TAC.

E. M. Madalena de Canossa: a atividade desenvolvida foi Feira das Nações, que faz parte do calendário da escola e já está na décima edição. 0 assunto abordado foi o continente africano, com o tema "África a mãe de todos". Envolveu todas as turmas do $6^{0}$ ao $9^{0}$ ano do ensino fundamental dos turnos matutino e vespertino.

E. M. Paulo Freire: a atividade desenvolvida foi a Feira de Ciências, evento que faz parte do calendário da escola. A temática abordada foi "Os impactos ambientais no riacho bacuri no entorno da escola". 0 trabalho foi desenvolvido com os alunos das turmas 7ํㅡ B e $\mathrm{C}$ do turno matutino.

E. M. Frei Tadeu: atividade desenvolvida durante a Feira de Ciências, que já faz parte do calendário da escola. A temática desenvolvida foi a construção de maquetes do Relevo Terrestre, especificamente mostrando as diferentes formas do relevo terrestre. Estiveram envolvidos na atividade alunos do $6^{0}$ ano do turno vespertino.

E. M. Giovanni Zanni: seguiu-se o cronograma de atividades previstas para o segundo semestre de 2016, no qual já estava prevista a Feira de Ciências. Nesta escola, o ensino fundamental funciona em dois turnos diferentes, a saber: matutino e vespertino e com professores diferentes. A turma do 60 A turno matutino escolheu trabalhar com o tema "Desperdício de alimentos" e a turma do 6o ano B com o tema "Conhecendo o riacho do Meio". Considera-se importante saber o que levou as turmas a escolherem os temas acima citados. A turma do 6을 justifica a escolha com base na experiência vivenciada no cotidiano da escola, já que, diariamente, os alunos presenciam o desperdício de alimentos da merenda escolar. Já a turma do 6ํㅜ ano B escolheu o riacho do Meio pelo fato de o mesmo ter a nascente próximo à escola e, no período chuvoso, o riacho transborda, alagando ruas no entorno da escola.

E. M. Wady Fiquene: a atividade realizada foi a Feira de Ciências e o tema trabalhado pelos alunos do 7o B turno vespertino foi o processo de urbanização. Na atividade, os alunos representaram o processo de urbanização de Imperatriz, usando como exemplo o perfil das famílias dos alunos da turma, pois a maioria é oriunda de outros municípios do Maranhão ou até mesmo de outros estados. No trabalho, além de explicar os processos migratórios para Imperatriz a partir de 1960, responsáveis pelo aumento da população urbana, os alunos utilizaram também o conceito de rede. Para materializar o referido conceito, usaram o mapa do Brasil, identificando Imperatriz como ponto central, e, com o auxílio de linhas e massa de modelar, identificavam a cidade de origem das famílias.

Ao final das atividades, os professores ficaram surpresos com o envolvimento e a criatividade dos alunos. Em geral, alunos que não gostavam de participar de atividades em sala de aula se integraram ao grupo e participaram ativamente de todas as atividades. As atividades realizadas em sala de aula em geral englobam resolução de exercícios do livro didático ou pesquisa sobre determinado tema, e a fonte de pesquisa geralmente é a internet. No caderno do professor, essas atividades contam como critério qualitativo de avaliação, sendo atribuído a penas um "X" para o aluno que cumpriu a atividade ou um "O" caso o aluno não cumpra a atividade. Se o aluno entendeu a atividade ou não, eis a questão. Pode-se destacar alguns pontos comuns nas cinco escolas: em geral, os temas dos trabalhos que envolvem as feiras de ciência interdisciplinar nas escolas eram escolhidos pela equipe pedagógica e sorteado para as turmas, mas, dessa vez, os temas foram levantados em sala pelos alunos e professores e dividido às equipes e, posteriormente, repassado à coordenação pedagógica e gestão da escola. Os banners, camisetas e todo o material utilizado pelas equipes foram construídos pelos alunos. Os professores tornaram-se orientadores de fato e não fizeram as atividades para os alunos como aconteceu em anos anteriores. 


\subsection{LIMITES E POSSIBILIDADES DO TRABALHO DOCENTE NA ATUALIDADE}

Diante de inúmeras realidades vivenciadas no cotidiano da escola o professor tem assumido um papel complexo no âmbito da escola, que vai desde ser professor, psicólogo, mediador de conflitos a responsável até pelo insucesso dos alunos no chão da sala de aula. Como visto até o momento, são muitos os impasses presentes no cotidiano da escola; não basta o domínio do saber profissional, disciplinar e/curricular, pois é no cotidiano da sala de aula que novas situações são postas a cada dia e o professor precisa enfrentá-las e resolvê-las da melhor forma possível.

\section{Quadro 29 - Desafios da prática docente na visão dos professores}

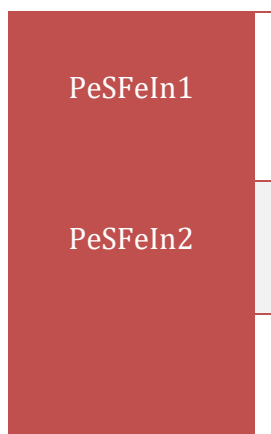

PeCFeIn1

PeCFeln2

PeCFeEx1

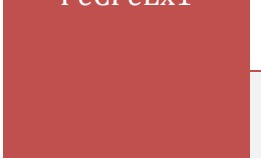

PeCFeEx2

PeCFeEx3

PeSFeEx

A falta de respeito do educando para com o professor, visto que o grau de compromisso está diminuindo a cada década. A base da educação é a família, e o que vimos é um grave desequilíbrio das famílias, que reflete na escola. A escola não é uma instituição que trabalha isolada, precisa do apoio e acompanhamento da família, o alicerce de uma sociedade é a família.

Hoje, os maiores desafios encontrados pelos professores são a indisciplina, a falta de apoio da família. Existem fatores que contribuem para esta ausência da família tais como: pais separados, falta de tempo dos pais, crianças que moram com avós ou cuidadores.

No contexto atual, os principais desafios dos professores dentro da estrutura escolar brasileira tanto pública como privada, está principalmente em saber orientar os alunos sobre o que estudar, devido à falta de um currículo definido pelo município que seja eficiente para ensinar os nossos jovens o que realmente interessa, em sua aplicabilidade de útil no seu cotidiano e em sua vida escolar, uma educação contínua e eficiente. Portanto, a falta de estrutura física de algumas escolas, violência, famílias desestruturadas e evasão escolar são fatores que influenciam de forma negativa as nossas escolas no processo de ensino e aprendizagem dos alunos, fatores esses provocados principalmente pela falta de prioridades e investimentos no setor educacional brasileiro.

A realidade de todas as escolas brasileiras é uma só. Acredito que todas as situações dentro de uma escola seriam resolvidas se as famílias fizessem o seu papel e educassem seus filhos em casa. Portanto, o grande desafio hoje do profissional da educação é ensinar aos alunos o que os mesmos devem aprender e não o que os pais devem ensinar, a educação, o respeito ao próximo, e o compromisso com os estudos. A parceria comunidade/escola deve ser colocada em prática para aperfeiçoar o aprendizado do aluno.

O desânimo dos alunos, a falta da família no acompanhamento dos alunos, a falta de investimentos sérios na educação colocou tudo nas costas dos professores, mas esqueceram de retribuir isso, como disse o senador Cristóvão Buarque, "o professor é cabeça e bolso".

Ser professor no Brasil é muito frustrante do ponto de vista do incentivo, das políticas públicas, que são mínimas para garantir os direitos de aprendizagem dos alunos. Considero um grande desafio o incentivo à pesquisa, o sucateamento ou a falta de acervos para a Geografia nas bibliotecas públicas ou escolar, A FALTA DE FORMAÇÃO para os licenciados, que passam todo o tempo aplicando aquele conhecimento que viu apenas na sua formação inicial, o grande número de alunos em cada sala, a falta de condições de trabalho e de recursos materiais para que a Ciência Geográfica seja mais bem trabalhada. Falta muito para realmente garantirmos os direitos de aprendizagem do aluno e a satisfação de um professor!!!!

Em primeiro lugar, é o fato de se fazer atrativo aos alunos, em uma era em que as mídias chamam atenção para tantos outros meios mais divertidos de se passar o tempo. Em segundo lugar, são os exemplos, ou a falta deles, por parte da família. Aquela família que tem o hábito do estudo, os alunos são mais interessados e esforçados, enquanto nas famílias com menos instrução, os alunos tendem a ser mais desinteressados, pois a cobrança é menor, quando existe. Em terceiro lugar, é a indisciplina que dificulta o processo, seguida da falta de apoio, tanto material como humano. Em resumo, vejo que o aluno está amparado de todas as formas, enquanto o professor está exposto a todas as situações adversas, sejam elas: falta de interesse dos alunos, falta de compromisso da família, falta de recursos materiais e principalmente o desafio de ensinar quem não quer aprender.

0 maior desafio que temos hoje é a falta de respeito do aluno com relação ao professor. A falta de valorização do professor por parte do aluno, da família, do poder público e da própria sociedade.

Fonte: Trabalho de Campo

De uma forma geral, os limites da prática docente esbarram em problemas como os citados acima, aliados a deficiências na formação inicial, ausência de investimentos na formação continuada, estrutura física 
deficitária nas escolas, falta de material didático e de apoio pedagógico para a realização de atividades, professores com diferentes formações trabalhando em áreas em que não têm o domínio dos saberes profissional e disciplinar. Para agravar a situação, a ausência de um currículo definido pelo município torna mais árduo o trabalho do professor sem formação em Geografia licenciatura, restando apenas a opção de usar o sumário do livro didático como modelo de currículo a ser seguido página a página.

A elaboração de uma proposta curricular (BNCC) com a participação da sociedade pode ser compreendida como uma possibilidade de estados, municípios e escolas aproximarem seus currículos com a realidade dos educandos. Da mesma forma, a reformulação do currículo dos cursos de formação de professores atendendo à Resolução do CNE 02/2015 aparece como uma possibilidade de um novo olhar para o campo da formação de professores. No entanto, muitas universidades não estão atentando para as necessidades do futuro professor frente às reformas no campo do currículo da educação básica; a preocupação está em atender às especialidades da pós-graduação mais do que atender ao perfil do profissional frente à nova realidade educacional pela qual o país está passando.

O domínio dos conceitos específicos do campo teórico e pedagógico da disciplina são importantes, mas não suficientes para a formação profissional do professor no momento atual. 0 profissional precisa, além de uma sólida formação conceitual, de uma capacidade de tomada de decisões, ou seja, de assumir uma postura crítico-reflexiva frente aos desafios cotidianos da profissão docente.

\section{CONCLUSÃO}

O desafio lançado na introdução deste trabalho foi o de investigar de que forma e porque os professores de Geografia do 6으 ao 9o ano do ensino fundamental da rede pública municipal da cidade de ImperatrizMA utilizam a linguagem cartográfica ao trabalharem com conteúdos geográficos em sala de aula, partindo da hipótese de que, a partir dos pressupostos da Teoria da Ação Comunicativa de Jürgen Habermas, entende-se que a linguagem cartográfica constitui um instrumento metodológico capaz de unir o mundo da vida (cotidiano) ao sistema (currículo), quando utilizado por professores de Geografia ao trabalharem com os conteúdos escolares no chão da sala de aula.

Assim, o objetivo geral que norteou esta pesquisa foi compreender, a partir dos pressupostos da TAC, a racionalidade os professores de Geografia dos anos finais do ensino fundamental na rede pública municipal da cidade de Imperatriz-MA ao utilizarem a linguagem cartográfica como instrumento metodológico no processo de transformação pedagógica dos conteúdos escolares em sala de aula.

Numa tentativa de melhor direcionar o rumo da investigação, os objetivos específicos foram ordenados da seguinte forma: fazer uma análise do processo de construção teórica da Geografia e da Cartografia a partir das matrizes epistemológicas que conduziram a construção do conhecimento científico e seus reflexos no ensino de Geografia; identificar as teorias que têm norteado os trabalhos da Cartografia Escolar e apontar as possíveis contribuições para o ensino no ensino da Geografia do $6^{\circ}$ ao 9 o ano do ensino fundamental; apontar como a linguagem cartográfica aparece no currículo de Geografia do 6o ao 9o ano (PCN, Diretrizes Curriculares Nacionais e do Estado do Maranhão) do ensino fundamental; caracterizar os pressupostos da Teoria da Ação Comunicativa de Jürgen Habermas, tendo em vista a sua aplicação no ensino de Geografia com ênfase no uso da linguagem cartográfica; caracterizar quem são os professores que ministram aulas de Geografia e como utilizam a linguagem cartográfica ao trabalharem com os conteúdos escolares em sala de aula; analisar, a partir do contato com os pressupostos da Teoria da Ação Comunicativa, as práticas dos professores afim de compreender a racionalidade que orienta suas práticas.

A pesquisa-ação colaborativa é uma modalidade em que o pesquisador está inserido no campo e tem a intenção de investigar e modificar o ambiente pesquisado, como no caso da pesquisa apresentada com os professores de Geografia dos anos finais do ensino fundamental da rede pública municipal da cidade de Imperatriz-MA. Portanto, a pesquisa-ação colaborativa apresenta um campo amplo, como também vastas possibilidades como metodologia de pesquisa, pois pode ser utilizada tendo como ponto de partida as reflexões dos professores, os problemas sociais com que convivem dentro da escola, os aspectos históricos da educação, etc.

Que lições se pode tirar ao trabalhar com observação participante? Pode-se dizer que são inúmeras as lições, pois o trabalho com observação implica saber ouvir o outro, escutar as conversas, ver os fatos, fazer uso de todos os sentidos ao longo do percurso. É preciso aprender quando perguntar e quando não perguntar, assim como que perguntas fazer na hora certa, bem como o que anotar. 
Várias das perguntas feitas nas entrevistas semiestruturadas são muitas vezes desnecessárias, pois o cotidiano revela outra realidade, devendo a coleta de informações não se restringir a questionários e entrevistas. Com o, os dados chegam ao pesquisador sem que ele faça qualquer esforço para obtê-los. As anotações em tempo real deixam de ser feitas, pois a memória do pesquisador se torna mais ativa e seletiva.

No tocante à relação da Geografia, Cartografia e seus reflexos no ensino de Geografia na educação básica, tem-se, até a década de 1970, a Geografia Tradicional, que se limitava a descrever as características físicas da superfície do planeta Terra - quais são os rios, as capitais, as fronteiras, áreas de florestas e etc. As informações eram transmitidas como prontas e acabadas, cabendo aos não geógrafos - alunos, cidadãos (ou não!) aceitá-las e pronto. É no momento de renovação do pensamento geográfico que se dá início à ruptura entre conhecimento geográfico e cartográfico. Tudo o que é associado à Geografia Tradicional começa a ser desprezado, como se não possuísse valor algum. E se algum geógrafo fizesse uso desse corpo instrumental era rotulado negativamente como sendo tradicionalista. Seeman e Girardi já haviam sinalizado para esta tradição, em especial pelos estudiosos da Geografia Crítica.

É preciso, portanto, compreender os mapas e todas as formas de representação espacial dentro do processo de comunicação, uma vez que transmitem uma informação ao leitor. Nesse sentido para fazer uma leitura do mapa é necessário o conhecimento da linguagem cartográfica, com destaque para a linguagem dos mapas que são os principais instrumentos cartográficos. Apresentam-se também alguns fundamentos da Semiologia Gráfica como o alfabeto cartográfico (ponto, linha e área), importantes para a análise das representações cartográficas presentes nos livros didáticos de Geografia do ensino fundamental anos finais.

Por outro lado, com o advento da Geografia Contemporânea ou Crítica, novas formas de representações foram surgindo, chegando até mesmo a receber um nome ou tornar-se área de estudo, com é o caso da Cartografia Social. Nesse caso, as representações do espaço não precisam seguir as regras rígidas da Cartografia Temática; o rio não precisa necessariamente ser azul, a vegetação não precisa ser verde, porque a subjetividade é um elemento que faz parte da representação espacial, pois, de acordo com a teoria da comunicação cartográfica de Kolacny, a neutralidade não faz parte do vocabulário das representações cartográficas.

Assim, a Cartografia Social defende a não neutralidade do mapa, uma vez que ele é uma construção social que traz muito mais do que a simples informação, mas também uma visão social. Essa não neutralidade, no entanto, precisa ser compreendida pelo leitor da representação para que ele não se engane com a informação à sua frente. Quem elabora uma representação precisa usar de um conhecimento sobre a área ou objeto a ser representado e quem lê a representação também precisa de um certo conhecimento sobre o que está sendo representado, pois, caso isso não aconteça, a comunicação possivelmente não acontecerá.

Se o ensino da Geografia não foi capaz de desenvolver nos estudantes uma forma de pensar geográfico como menciona Cavalcanti (1998), a Cartografia Geográfica ou Cartografia Escolar deve levar o aluno ao entendimento da lógica espacial dos fenômenos, e não há dúvidas de que os mapas são instrumentos importantes no processo de ensino e de aprendizagem. Sabe-se, entretanto, que tanto os professores quanto os alunos leem pouco nos mapas, ou seja, ainda não são capazes de compreender a dinâmica espacial a partir desses documentos. Como resultado, tem-se práticas docentes construídas com a ausência de representações espaciais ou com o uso acrítico das representações presentes nos livros didáticos de Geografia, que em geral utilizam mapas elaborados pelo IBGE.

Passados 40 anos da origem da Cartografia Escolar como linha de pesquisa, percebe-se que muito já foi feito, porém, os desafios ainda existem para que essa linha de pesquisa possa fazer parte da formação inicial do professor de Geografia como um componente curricular e seu reflexo na educação básica seja sentido em curto e médio prazo em todo o território nacional.

A Cartografia Escolar tem apresentado um crescimento exponencial, em especial a partir da última década do século passado, principalmente com a aproximação dessa área com o ensino de Geografia na educação básica. No início deste século, as pesquisas têm apresentado um crescimento partindo de trabalhos de dissertação de mestrado e teses de doutorado e, mais recentemente, de publicações em anais de eventos, periódicos e livros. Foram identificadas algumas teorias que têm norteado os trabalhos desta área como: Epistemologia Genética de Jean Piaget, presente nos trabalhos ligados às relações espaciais (topológica, projetiva e euclidiana), que norteou principalmente os trabalhos com os anos inicias do ensino fundamental. Outras teorias têm subsidiado os trabalhos dessa área. Dentre elas, merece destaque a Teoria Histórico Cultural de Vygosty, presente nos trabalhos com mapas mentais e raciocínio espacial, e 
Semiologia Gráfica de Jaques Bertin, que tem contribuído com os trabalhos ligados à produção de atlas escolares.

A contribuição desses trabalhos aparece em forma de novos conceitos incorporados ao arsenal teórico da Cartografia e Geografia Escolar, entre os quais é possível mencionar os conceitos de Cartografia Escolar, Cartografia para escolares, linguagem cartográfica, alfabetização cartográfica, letramento cartográfico, Cartografia Tátil, maquetes, mapas mentais, croqui. Esses conceitos já aparecem nos currículos escolares. $\mathrm{Na}$ tentativa encontrar respostas para uma das questões norteadoras deste trabalho, referente ao lugar da linguagem cartográfica no currículo escolar, buscou-se suporte nos PCN, no Referencial Curricular de Geografia do Ensino Fundamental do 6o a o 9o ano do Estado do Maranhão e no texto final do Componente Geografia da Base Nacional Comum Curricular.

Na década de 1990, a Cartografia já aparecia nos PCN em forma de bloco temático no terceiro ciclo. Como reflexo, os livros didáticos de Geografia do 6ํㅜ e 7ํㅡ anos apresentam conteúdos ligados aos conteúdos cartográficos, uns como conteúdo obrigatório e outros como anexo. Na BNCC, a Cartografia aparece como uma linguagem e presente ao longo dos nove anos do ensino fundamental como um bloco temático e, dentro de cada ano, apresenta conceitos que têm a intenção de desenvolver o raciocínio espacial.

Como dito no Capítulo 3, poucos municípios maranhenses usam esse documento como currículo, haja vista que, após sua aprovação e publicação, não houve a formação continuada prevista no projeto inicial. Diante do descumprimento desse item da proposta, alguns municípios se recusaram a trabalhar com o novo currículo. No entanto, algumas escolas têm procurado definir o que chamam de currículo mínimo para o ensino fundamental, ou seja, conteúdos considerados importantes para a formação básica em cada componente curricular.

Na BNCC para o ensino fundamental de nove anos, as cinco unidades temáticas definidas seguem o currículo do $1^{\circ}$ ao $9^{\circ}$, mudando apenas os objetos de conhecimentos e as habilidades. Vale destacar que a quarta unidade temática, "Formas de representação e pensamento espacial", indica a possibilidade de inserção da tão sonhada "alfabetização cartográfica" desde os anos iniciais, considerada ponto de partida para o desenvolvimento do pensamento espacial, como defendem os pesquisadores da Cartografia Escolar que têm dedicado seus estudos ao processo de iniciação a leitura e interpretação de mapas (PASSINI, 2012).

Na TAC, a linguagem é vista como possibilidade de entendimento entre sujeitos através de contextos comunicativos, da mesma forma Kolacny, ao propor a teoria da comunicação cartográfica, viu no mapa um meio de comunicação entre dois sujeitos sobre uma determinada realidade. Nesse sentido, a linguagem cartográfica pode ser utilizada com o intuito de comunicação entre professor e aluno, bem como entre alunos, uma vez que se utiliza nas escolas apenas duas formas de linguagem: a fala e a escrita. Acredita-se que a representação gráfica e cartográfica pode ser utilizada em situações didáticas no chão da sala de aula guiada por uma racionalidade pedagógica do tipo comunicativa. Como já foi dito em outras partes deste trabalho, não é intenção receitar aos professores a forma correta de uso da linguagem cartográfica em sala de aula, pois sabe-se que cada conteúdo, cada turma, cada escola, cada professor tem uma subjetividade e a dinâmica do espaço escolar é regida pela incerteza.

Os professores da educação básica, em especial os do ensino fundamental anos finais são conscientes da importância e da necessidade de utilizarem a linguagem cartográfica em sala de aula, porém muitos deles não têm o conhecimento suficiente para isso. Esse problema acompanha o professor desde a formação inicial e perdura na prática pedagógica, pois estados e municípios não oferecem formação continuada no sentido de suprir essa lacuna. Esse é um dos maiores desafios da cartografia escolar para os próximos anos frente à nova proposta curricular.

Acredita-se que, independente da formação acadêmica, o professor é capaz de conduzir o processor de transformação pedagógica dos conteúdos escolares em sala de aula. Para isso, ele deve fazer uso de diversas ferramentas que possam lhe auxiliar em sua prática cotidiana. 0 que lhe falta talvez seja a habilidade pedagógica de selecionar recursos materiais adequados para proporcionar ao aluno uma experiência diferenciada e que permita materializar os conteúdos conceituais trabalhados em sala em conteúdos atitudinais úteis à sua vida em sociedade.

Acredita-se, portanto, que o uso da linguagem cartográfica como instrumento didático durante os processos pedagógicos (aulas) aliada aos princípios da Teoria da Ação Comunicativa pode orientar o trabalho do professor rumo a uma prática emancipatória e que o resultado desse processo é uma aprendizagem que satisfaça ambos os envolvidos. 
Em relação aos professores que ministram aulas de Geografia na rede pública municipal em ImperatrizMA, boa parte não tem formação em Geografia, estão ministrando aula nessa disciplina para completar carga horária (16h/a) ou porque optaram por trabalharem em escolas próximas às suas residências, mesmo não tendo o domínio dos conteúdos conceituais da disciplina. É valido citar ainda que muitos trabalham dois ou três turnos, em diferentes escolas e diferentes níveis de ensino e até em municípios diferentes.

O fato de não possuírem formação na área de atuação, aliado a outros fatores, como a elevada carga horária de trabalho semanal e a ausência de um currículo a ser seguido, resulta na utilização do livro didático como única fonte de saber. Durante as aulas, os docentes acabam seguindo uma espécie de ritual, obedecendo ao esquema aula expositiva-atividade-visto nos cadernos de atividades. Esse ritual faz parte da rotina de muitos professores, inclusive dos que têm formação em Geografia. Portanto, o saber da prática prevalece no chão da sala de aula, porque segundo os professores que utilizam esse método, os alunos não colaboram para a realização de atividades com uma dinâmica diferente. Daí citam o problema da indisciplina, em que fazer atividades (tarefas) seria uma espécie de "punição" para a turma.

Boufleuer (2001) afirma que é impossível que o pesquisador que investiga a prática docente consiga identificar em campo se as ações do professor são do tipo estratégica ou comunicativa. Para o autor, o cotidiano da escola é regido pelo munda da incerteza. Sendo assim, somente no chão da sala de aula, onde ocorrem as relações sociais entre alunos e professores, é possível compreender a racionalidade. No entanto, vale lembrar que, a cada dia, cada novo conteúdo, nova atividade, é necessária uma nova racionalidade.

O objetivo desse trabalho não foi classificar os professores em docentes guiados (ou não) por uma racionalidade instrumental ou comunicativa, mas sim tentar compreender os elementos que estão por trás das tomadas de decisões, tais como: atuarem em uma área diferente da qual eles foram formados, carga de trabalho elevada, atuação em diferentes níveis de ensino, baixo salário, elevado número de alunos por sala, péssimas condições de trabalho, ausência de um currículo e um dos piores, a indisciplina dos alunos e a ausência dos pais no acompanhamento da vida escolar dos filhos.

Durante o período de elaboração do plano de ação, os docentes apresentaram diferentes propostas de atividades e executaram projetos que resultaram em melhoria do ensino nas aulas e realização de atividades culturais nas escolas; ensaiaram novas práticas de ensinar com resultados efetivos de melhoria da aprendizagem, abandonando os objetivos já elaborados a partir dos conteúdos do livro didático e iniciando o trabalho com os objetivos de aprendizagem com foco na realidade e reais necessidades dos alunos. Os professores ampliaram suas competências no que se refere aos conteúdos específicos da Geografia e Cartografia, bem como suas competências pedagógicas.

Ao final da pesquisa nas escolas, algumas conquistas podem ser apontadas, tais como: perceber que os professores desenvolveram habilidades fundamentais para a melhoria da prática docente, realizando pesquisa sobre o entrono das escolas; utilização de instrumentos e metodologias de pesquisa como a elaboração, aplicação e tabulação de questionários para traçar o perfil da turma ou conhecer o entorno da escola; observar que houve uma ampliação dos espaços de atuação coletiva, saindo das reuniões de conselho de classe e participando de reuniões de discussão da BNCC; escolha do livro didático; as reuniões do sindicato da categoria; identificar que os envolvidos efetivaram práticas de análises dos problemas da escola, criando nela uma cultura de análise, interpretação e intervenção.

Portanto, compreender a racionalidade que move a tomada de decisão em situações de aula, passa antes de tudo pela formação inicial momento em que o docente tem o contato com o saber profissional e da disciplina, bem como o contato com o saber curricular no início da trajetória profissional e se constrói no cotidiano da escola no exercício da profissão docente. É no chão da sala de aula que os docentes enfrentam os maiores desafios do fazer pedagógico frente a diferentes realidades que se apresentam diariamente e que diante delas o professor precisa decidir qual reservatório de saber utilizar para contribuir no processo de formação de sujeitos autônomos e emancipados. No entanto a pesquisa revela que o abismo entre o saber universitário e o saber escolar precisa ser diminuído, para que os objetivos de ensino e aprendizagem sejam alcançados, pois o currículo da universidade não tem levado em conta as reais necessidades da educação básica. Acredita-se que esse seja o início de uma grande mudança, a universidade formar profissionais que possam atuar com autonomia no ensino básico e atender as reais necessidades deste nível de ensino. 


\section{Referências}




\section{REFERÊNCIAS}

[1] ABDALLA, M. de F. B. A pesquisa-ação como instrumento de análise e avaliação da prática docente. Ensaio, Rio de Janeiro, v. 13, n. 48, p. 383-400, jul./set. 2005

[2] ADORNO, T. W. Educação e emancipação. Rio de Janeiro: Paz e Terra, 2000.

[3] ALARCÃO, I. Escola reflexiva e nova racionalidade. Artmed Editora, 2001.

[4] ALMEIDA, R. D. de. (Org.). Cartografia Escolar. São Paulo: Contexto, 2007.

[5] ALMEIDA, R. D. de. (Org.). Novos rumos da Cartografia Escolar: currículo, linguagem e tecnologia. São Paulo: Contexto, 2011.

[6] ALMEIDA, R. D. de. Cartografia para Crianças e Escolares: uma área de conhecimento? Revista Brasileira de Educação em Geografia, v. 7, n. 13, p. 10-20, 2017.

[7] ALMEIDA, R. D. de. Cartografia para crianças e escolares: uma área de conhecimento? Revista Brasileira de Educação em Geografia, v. 7, n. 13, p. 10-20, 2017.

[8] ALMEIDA, R. D. de. Pesquisas em Cartografia Escolar. In: Boletim Paulista de Geografia. n. 90. v. 2. São Paulo: AGB, 2010. p. 97-107.

[9] ALMEIDA, R. D. de. Uma proposta metodológica para a compreensão de mapas geográficos. São Paulo, SP. 1994. Tese (Doutorado em Educação). Universidade de São Paulo. 1994.

[10] ALMEIDA, R. D. de; ALMEIDA, R. A. de. Fundamentos e perspectivas da Cartografia Escolar no Brasil. Revista Brasileira de Cartografia, Rio de Janeiro, n. 66, v. 4, jul./ago. 2014. p. 885-897. ISSN 1808-0936

[11] ALMEIDA, R. D. de; PASSINI, E. Y. O espaço geográfico: ensino e representação. São Paulo: Contexto, 1989.

[12] ALVES-MAZZOTTI, A. J. O planejamento de pesquisas qualitativas em educação. Cadernos de pesquisa, n. 77, p. 53-61, maio, 1991.

[13] ALVES-MAZZOTTI, A. J.; GEWANDSZNAJDER, F.O método nas ciências naturais e sociais: pesquisa quantitativa e qualitativa. 2. ed. São Paulo: Pioneira, 2000.

[14] ANDRADE, M. C. de. Geografia, ciência e sociedade: uma introdução à análise do pensamento geográfico. São Paulo: Atlas, 1987.

[15] ANDRÉ, M. E. D. A. de. Pesquisa em educação: buscando rigor e qualidade. Cadernos de pesquisa, n. 113, p. 51-64, julho, 2001.

[16] ANDRÉ, M. E. D. A. de. Pesquisa em educação: questões de teoria e de método. Educação \& tecnologia, v. 10, n. 1, jan./jul. 2005. p. 29-35.

[17] ANDRÉ, M. E. D. A. de. Texto, contexto e significados: algumas questões na análise de dados qualitativos. Cadernos de pesquisa, n. 45, p. 66-71, maio, 1983.

[18] ARCHELA, R. S. Imagem e representação gráfica. GEOGRAFIA (Londrina), v. 8, n. 1, p. 5-11, 1999.

[19] ARCHELA, R. S.; ARCHELA, E. Correntes da Cartografia teórica e seus reflexos na pesquisa. GEOGRAFIA (Londrina), v. 11, n. 2, p. 161-170, jul./dez. 2002.

[20] ASSELIN, V. Corrupção e grilagem nas terras do Tocantins. Rio de Janeiro: Vozes, p. 146-168, 1980.

[21] AZAMBUJA, L. D. de. Representações (carto) gráficas, linguagens e novas tecnologias no ensino de Geografia. In: CASTELLAR, Sonia M. V.; CAVALCANTI, Lana de S.; CALLAI, Helena C. Didática da Geografia: aportes teóricos e metodológicos. São Paulo: Xamã Editora, 2012. p. 199-211.

[22] BALDISSERA, A. Pesquisa-ação: uma metodologia do "conhecer" e do "agir" coletivo. Sociedade em Debate, v. 7, n. 2, p. 5-25, 2012.

[23] BANNELL, R. I. Habermas \& a educação. Autentica, 2013.

[24] BARBIER, R. A pesquisa-ação. Tradução Lucie Didio. Brasília: Plano, 2002.

[25] BARBOSA, R. dos S. O ensino de Geografia na Realidade de Imperatriz: encontros e (des) encontros entre a Geografia Acadêmica e Geografia Escolar. In: Encontro Nacional de Geógrafos, 16. 2010, Porto Alegre. Anais...Porto Alegre: AGB, 2010. p. 01- 06.

[26] BATISTA, S. S. dos S. Teoria crítica e teorias educacionais: uma análise do discurso sobre educação. Educação \& Sociedade, v. 21, n. 73, p. 182-205, 2000.

[27] BERTIN, J. Semiology of graphics: Diagrams, networks, maps, Madison: The University of Wisconsin Press, 1967. 
[28] BOGDAN, R. C.; BIKLEN, S. K. Investigação qualitativa em educação: uma introdução à teoria e aos métodos. Porto: Editora Porto, 1994.

[29] BOUFLEUER, J. P. Pedagogia da ação comunicativa: uma leitura de Habermas. 3. Ed. Ijuí, RS: Editora Unijuí, 2001.112p.

[30] BRASIL, Ministério da Educação. Base Nacional Comum Curricular. Geografia: Ensino Fundamental. Brasília: MEC, 2017.

[31] BRASIL, Ministério da Educação. Parâmetros Curriculares Nacionais. Geografia ensino fundamental. Brasília: MEC, 1998.

[32] BRASIL. Ministério da Educação. Lei no 13.005/2014. Aprova o Plano Nacional de Educação-PNE e dá outras providências. Diário Oficial da União, 25 de junho de 2014.

[33] BRITO, A. X. de; LEONARDOS, A. C. A identidade das pesquisas qualitativas: construção de um quadro analítico. Cadernos de Pesquisa, n. 113, p. 7-38, julho, 2001.

[34] BRITO, D. S., RODRIGUES, J. da S., BARBOSA, R. dos S. As dificuldades docentes em trabalhar os conteúdos de Geografia tendo como instrumento a Cartografia, na rede pública municipal de Imperatriz-MA. In: XI Encontro Nacional de Prática de Ensino de Geografia, 2011, Goiânia. Anais... Goiânia: UFG, 2011.

[35] BRZEZINSKI, I.; GARRIDO, E. Estados da arte sobre formação de professores nos trabalhos apresentados no GT 8 da ANPEd: 1990-1998. In: Reunião Anual da Associação Nacional de Pós-Graduação e Pesquisa em Educação ANPEd, 22., Caxambu, 1999. Anais. Caxambu, MG, 1999. 1CD.

[36] BUITONI, M. M. S. Ensino de Geografia: a produção científica apresentada nos Espaços de Diálogos e Práticas da Associação dos Geógrafos Brasileiros (2008-2012). Terra Livre, v. 2, n. 42, p. 47-82, 2014.

[37] CALLAI, E. C. A Formação do Profissional da Geografia. 2. ed. Ijuí, Rio Grande do Sul: Editora UNIJUÍ, 2003.

[38] CALLAI, H. C. O lugar e o ensino-aprendizagem da Geografia. In: PEREIRA, Marcelo Garrido (Org.). La espessura del lugar: reflexiones sobre el espacio em el mundo educativo. Santiago de Chile: Universidad Academica de Humanismo Cristiano. 2009. Cap. VIII.

[39] CALlaI, H. C.; CAVAlCANTI, L. de S.; CASTELlAR, S. M. V.; SOUZA, V. C. de. O Ensino de Geografia nos Trabalhos Apresentados no XI ENANPEGE. Revista da ANPEGE. Número Especial. p. 43-55, n. 18, 2016.

[40] CAMARGO, J. C. G.; REIS JÚNIOR, D. F. da C. Considerações a respeito da Geografia neopositivista no Brasil. 2004. Disponível em: http://repositorio.bce.unb.br/bitstream/10482/5917/1/ARTIGO_ConsideracoesGeografia Neopositivista.pdf

[41] CARR, W.; KEMMIS, S. Teoria crítica de la enseñanza. Barcelona: Martinez Roca, 1988.

[42] CASTELLAR, S. M. V. A Cartografia e a construção do conhecimento em contexto escolar. In: ALMEIDA . R. D. de. (Org.). Novos rumos da Cartografia escolar: currículo, linguagem e tecnologia. São Paulo: Contexto, p. 121-135, 2011.

[43] CASTEllaR, S. M. V.; CAVAlCANTI, L. de S.; CALlaI, H. C. Didática da Geografia: aportes teóricos e metodológicos. São Paulo: Xamã Editora, 2012.

[44] CASTEllaR, S. M. V; MUNHOZ, G. B. Conhecimentos Escolares e Caminhos Metodológicos. São Paulo: Xamã, 2012.

[45] CAVALCANTI, L. de S. Concepções Teórico-metodológicas da Geografia Escolar no mundo contemporâneo e abordagens no ensino. In: DALBEN, A.; DINIZ, J.; LEAL, L.; SANTOS, L. (Org.). Convergências e Tensões no campo da formação e do trabalho docente. 1. ed. Belo Horizonte: Autêntica, 2010.

[46] CAVALCANTI, L. de S. Para Onde Estão Indo as Investigações Sobre Ensino de Geografia no Brasil? Um Olhar Sobre Elementos da Pesquisa e do Lugar Que Ela Ocupa Nesse Campo. Boletim Goiano de Geografia, v. 36, n. 3, p. 399 419, dez. 2016.

[47] CAVALCANTI, L. de S. Práticas do Ensino de Geografia. São Paulo: Alternativa, 2002.

[48] CAVALCANTI, L. de S. Geografia, escola e construção de conhecimentos. Papirus Editora, 1998.

[49] CHAPANI, D. T.; CARVALHO, L. M. O. de. As políticas públicas na história da formação de uma professora de ciências: uma análise a partir de contributos do pensamento habermasiano. Investigações em Ensino de Ciências, v. 14, n. 3, p. 321-339, 2016.

[50] CHIZZOTTI, A. A pesquisa qualitativa em ciências humanas e sociais: evolução e desafios. Revista portuguesa de educação, v. 16, n. 2, p. 221-236, 2003.

[51] CHRISTOFOLETTI, A. Perspectivas da Geografia. 2. ed. São Paulo: DIFEL, 1985.

[52] CLAVAL, P. História da Geografia. Tradução de José Braga Costa. Lisboa: Edições 70, 2006. 
[53] CORREA, R. L. Espaço: um conceito-chave da Geografia. In: CASTRO, I. E. (Org.). Geografia: conceitos e temas. Rio de Janeiro: Bertrand Brasil, p. 15-47, 1995.

[54] CORREA, R. L. Reflexões sobre Paradigmas, Geografia e Contemporaneidade. Revista da ANPEGE, v. 7, n. 1, número especial. p. 59-65, out. 2011.

[55] CORREA, R. L. Introdução à Geografia cultural. Bertrand Brasil, 2003.

[56] CORRÊA, R. L. Região e organização espacial. Editora Ática, 1986.

[57] CORREA, R. L. Região e organização espacial. Editore Ática, 1986.

[58] COSTA, F. R. da; ROCHA, M. M. Geografia: conceitos e paradigmas - apontamentos preliminares. Revista GEOMAE, Campo Mourão, PR, v. 1, n. 2, p. 25-56, 2º semestre de 2010.

[59] COUTINHO, C. P. et al. Investigação-acção: metodologia preferencial nas práticas educativas. Psicologia, Educação e Cultura. V. 13, n. 2, p. 455-479. 2009.

[60] DESGAGNÉ, S. O conceito de pesquisa colaborativa: a ideia de uma aproximação entre pesquisadores universitários e professores práticos. Revista Educação em Questão, v. 29, n. 15, 2007.

[61] DEVECHI, C. P. V. A racionalidade comunicativa de Habermas e a possibilidade de crítica e objetividade na produção do conhecimento educacional empírico. Linhas Críticas, Brasília-DF, v. 16, n. 31, jun./dez. 2010. p. 259-273.

[62] DIAS, A. M.; THERRIEN, J.; BRANDÃO, M. de L. P. As Transformações do saber na Sociedade Contemporânea e a Formação de Professores. In: BRANDÃO, M. de L. P.; DIAS, A. M. I. (Orgs.). Imagens distorcidas: atualizando o discurso sobre o telensino no Ceará. Fortaleza: Imprensa Universitária, 2003. p. 25-34.

[63] DINIZ-PEREIRA, J. E. Da racionalidade técnica à racionalidade crítica: formação docente e transformação social. Perspectivas em Diálogo: revista de educação e sociedade, Navaraí, v. 1, n. 1, jan./jun. 2014. p. 34-42.

[64] DUARTE, R. G. A linguagem cartográfica como suporte ao desenvolvimento do pensamento espacial dos alunos na educação básica. Revista Brasileira de Educação em Geografia, v. 7, n. 13, p. 187-206, 2017.

[65] DUARTE, R. Pesquisa qualitativa: reflexões sobre o trabalho de campo. Cadernos de pesquisa, n. 115, p. 139154, março, 2002.

[66] EDNEY, M. H. Putting "Cartography" into the history of cartography: Arthur H. Robinson, David Woodward, and the creation of a discipline. Cartographic perspectives, n. 51, p. 14-29, Spring, 2005.

[67] ENGEL, G. I. Pesquisa-ação. Educar em Revista, n. 16, p. 181-191, 2000.

[68] FARINON, M. J. Teoria Crítica e Educação: a dimensão ético-educacional do sujeito estético em Adorno. In: Congresso Internacional de Filosofia e Educação. Anais... 5. Caxias do Sul, RS, 2010.

[69] FERNANDES, B. M. Movimento social como categoria geográfica. Terra Livre, n. 15, p. 59-86, 2000.

[70] FERNÁNDEZ, P. I. A.; BUCHROITHNER, M. F. Paradigms in cartography: an epistemological review of the 20th and 21st centuries. Berlin: Springer Science, 2014. DOI 10.1007/978-3-642-38893-4.

[71] FERREIRA, N. S. de A. As pesquisas denominadas "estado da arte". Educação \& Sociedade, ano XXIII, nº 79, Agosto/2002.

[72] FLICK, U. Desenho da pesquisa qualitativa. Tradução: Roberto Cataldo Costa. Porto Alegre: Artmed, 2009.

[73] FONSECA, F. P.; OLIVA, J. T. A Geografia e suas linguagens: o caso da Cartografia. In: CARLOS, Ana Fani Alessandri (Org.). A Geografia na sala de aula. 5. ed. São Paulo: Editora Contexto, 2003. p. 62-78.

[74] FONSECA, J. J. S. Metodologia da Pesquisa Científica. Fortaleza: UECE, 2002.

[75] FONTANA, A; FREY, J. The art of science. The handbook of qualitative research, p. 361-376, 1994

[76] FRANCISCHETT, M. N. A Cartografia no ensino de Geografia: a aprendizagem mediada. 2001. 2001. Tese de Doutorado. Tese (Doutorado em Geografia). Universidade Estadual Paulista Júlio de Mesquita Filho, UNESP, Presidente Prudente-SP.

[77] FRANCO, M. A. S. Pedagogia da pesquisa-ação. Educação e pesquisa, v. 31, n. 3, p. 483-502, set./dez. 2005.

[78] FRANCO, M. A. S. Pesquisa-Ação Pedagógica: práticas de empoderamento e de participação. Educação Temática Digital, v. 18, n. 2, p. 511, 2016.

[79] FREITAG, B. Habermas e a teoria da modernidade. Caderno CRH, Salvador. v. 8, n. 22, jan./jun. 1995. p. 138163.

[80] FREITAS, S. A.; MASETTO, M. T.; FELDMANN, M. G. O currículo no contexto atual: a interface com o trabalho pedagógico. Revista Cocar, n. 2, p. 53-75, 2017. 
[81] GARBIN, E. P.; SANTIL, F. L. de P.; BRAVO, J. V. M. Semiótica e a teoria da Visualização Cartográfica: considerações na análise do projeto cartográfico. Boletim de Ciências Geodésicas, v. 18, n. 4, 2012.

[82] GERHARDT, T. E.; SILVEIRA, D. T. Métodos de pesquisa. Porto Alegre: UFRGS Editora, 2009.

[83] GIL, A. C. Como elaborar projetos de pesquisa. 4. ed. São Paulo: Atlas, 2007.

[84] GIRARDI, E. P. Proposição teórico-metodológica de uma Cartografia geográfica crítica e sua aplicação no desenvolvimento do atlas da questão agrária brasileira. Presidente Prudente, SP, 2008. 347 f. Tese (Doutorado em Geografia). Faculdade de Ciência e Tecnologia da Universidade Estadual Paulista, 2008.

[85] GIRARDI, G. Mapas desejantes: uma agenda para a Cartografia Geográfica. Pró-Posições, Campinas, v. 20, n. 3, p. 60, 2009.

[86] GODOY, A. S. Pesquisa qualitativa: tipos fundamentais. Revista de Administração de empresas, v. 35, n. 3, p. 20-29, mai./jun. 1995.

[87] GODOY, A. S. Uma revisão histórica dos principais autores e obras que refletem esta metodologia de pesquisa em Ciências Sociais. Revista de Administração de Empresas, São Paulo. v. 35, n. 2, p. 57-63, mar./abr. 1995.

[88] GOMES, H. Reflexões sobre Teoria e Crítica em Geografia. Goiânia: CEGRAF/UFG, 1991.

[89] GOMES, P. C. da C. Geografia e modernidade. Bertrand Brasil, 1996.

[90] GONÇALVES, M. A. S. Teoria da ação comunicativa de Habermas: possibilidades de uma ação educativa de cunho interdisciplinar na escola. Educação \& Sociedade, v. 20, n. 66, p. 125-140, 1999.

[91] GONDIM, S. M. G. Grupos focais como técnica de investigação qualitativa: desafios metodológicos. Paidéia, n. 12. v, 24. 2003. p. 149-161.

[92] GÜNTHER, H. Como elaborar um questionário (Série: Planejamento de Pesquisa nas Ciências Sociais, $\mathrm{n}$ o 01). Brasília, DF: UnB, Laboratório de Psicologia Ambiental, 2003. p. 1-15.

[93] GÜNTHER, H. Pesquisa qualitativa versus pesquisa quantitativa: esta é a questão. Psicologia: teoria e pesquisa, v. 22, n. 2, p. 201-210, mai./ago. 2006.

[94] GUTIERREZ, G. L.; ALMEIDA, M. A. B. de. Teoria da Ação Comunicativa (Habermas): estrutura, fundamentos e implicações do modelo. Veritas. Porto Alegre. v. 58. n. 1, jan./abr. 2013. p. 151-173.

[95] HABERMAS, J. Teoria do Agir Comunicativo: Sobre a crítica da razão funcionalista. Tradução Flávio Beno Siebeneichler. Volume 2. São Paulo: Editora WMF Martins Fontes, 2012.

[96] HABERMAS, J. Conhecimento e interesse: com um novo posfácio. Rio de Janeiro: Guanabara, 1987.

[97] HABERMAS, J. Teoria do agir comunicativo: Racionalidade da ação e racionalização social. Tradução de Paulo Astor Soethe. Revisão técnica Flávio Beno Siebeneichler. Volume 1. São Paulo: Editora WMF Martins Fontes, 2012.

[98] HEAD, C. G. The map as natural language: a paradigm for understanding. Cartographica: The International Journal for Geographic Information and Geovisualization, v. 21, n. 1, p. 1-32, 1984.

[99] HOLZER, W. O conceito de lugar na Geografia cultural-humanista: uma contribuição para a Geografia contemporânea. Geographia, v. 5, n. 10, 2009.

[100] IMPERATRIZ. Lei n. 1.582/2015 aprova o Plano Municipal de Educação da Cidade de Imperatriz para o decênio 2014-2023. Imperatriz, 2015.

[101] KAERCHER, N. A. A Geografia escolar na prática docente: a utopia e os obstáculos epistemológicos da Geografia Crítica. 2004. 363 f. Tese de Doutorado. Tese (Doutorado em Geografia) Curso de Pós-Graduação em Geografia, Universidade de São Paulo. São Paulo. 2004.

[102] KATUTA, A M. Ensino de Geografia x mapas em busca de uma reconciliação. Presidente Prudente, SP. 1997. Dissertação (Mestrado em Geografia). Universidade Estadual Paulista. Presidente Prudente, 1997.

[103] KATUTA, A. M. A linguagem cartográfica no ensino superior e básico. In: PONTUSCHKA, Nídia Nacib; OLIVEIRA, Ariovaldo Umbelino de. Geografia em perspectiva: ensino e pesquisa. 3. ed. São Paulo: Contexto, 2009. p. $133-140$.

[104] KOERICH, M. S.; BACKES, D. S., SOUSA, F. G. M., ERDMANN, A. L., \& ALBURQUERQUE, G. L. Pesquisa-ação: ferramenta metodológica para a pesquisa qualitativa. Revista Eletrônica de Enfermagem, v. 11, n. 3, 2009.

[105] KOLÁČNÝ, A. Cartographic information-a fundamental concept and term in modern cartography. The cartographic journal, v. 6, n. 1, p. 47-49, 1969.

[106] KOZEL, S.; GALVÃO, W. Representação e ensino de Geografia: contribuições teórico-metodológicas. Ateliê Geográfico, v. 2, n. 3, p. 33-48, 2008.

[107] LE SANN, J. G. Documento cartográfico: considerações gerais. Geografia e Ensino. n. 3, p. 3-7, 1983. 
[108] LEWIN, K. Action research and minority problems. Journal of social issues, v. 2, n. 4, p. 34-46, 1946.

[109] LIBÂNEO, J. C. As teorias pedagógicas modernas revisitadas pelo debate contemporâneo na educação. In: LIBÂNEO, José Carlos; SANTOS, Akiko (Orgs.). Educação na era do conhecimento em rede e transdisciplinaridade. 3. ed. Campinas: Atomoealinea, 2005. p. 19-63.

[110] LIBAULT, A. Os quatro níveis da pesquisa geográfica. Universidade de São Paulo, Instituto de Geografia, 1971.

[111] LOPES, C. S.; PONTUSCHKA, N. N. O conhecimento pedagógico do conteúdo na prática profissional de professores de Geografia. GEOUSP: Espaço e Tempo (Online), v. 19, n. 1, p. 76-92, 2015.

[112] LÜDKE, M.; ANDRÉ, M. E. D. A. Pesquisa em educação: abordagens qualitativas. 2. Ed. Rio de Janeiro: E.P.U. 2014

[113] MACHADO, J. de C. et. al. A racionalidade comunicativa na literatura internacional: uma análise bibliométrica. Revista Espacios. v, 38. n. 11, ano 2017. p. 5-21.

[114] MARAFON, G. J. et al. Pesquisa Qualitativa em Geografia: Reflexões teórico-conceituais e aplicadas. Rio de Janeiro: SciELO-EDUERJ, 2013.

[115] MARANHÃO. Lei no 10.099/2014 Diário Oficial do estado. ANO CVIII. São Luís: Poder Executivo. 11 de junho de 2014.

[116] MARCONI, M. de A.; LAKATOS, E. M. Metodologia científica. São Paulo: Atlas, 2004.

[117] MARTINELLI, M. Comunicação cartográfica e os atlas de planejamento. 1984. (Doutorado em Geografia). Universidade de São Paulo. São Paulo, SP. 1984.

[118] MARTINELLI, M. As representações gráficas da Geografia: os mapas temáticos. 1999. 258f. Tese de Doutorado. Tese (Livre-docência). FFLCH-USP, São Paulo. 1999.

[119] MARTINS, H. H. T. de S. Metodologia qualitativa de pesquisa. Educação e pesquisa, v. 30, n. 2, p. 289-300, mai./ago. 2004.

[120] MEC. INEP. Nota Técnica n. 039/2014. Censo escolar. Linha de base. Brasília: INEP, 2015.

[121] MEYRELLES DE JESUS, D.; VIEIRA, A. B.; EFFGEN, A. P. S. Pesquisa-Ação Colaborativo-Crítica: em busca de uma epistemologia. Educação \& Realidade, v. 39, n. 3, 2014.

[122] MINAYO, M. C. de S. Pesquisa social: teoria, método e criatividade. Editora Vozes Limitada, 2011.

[123] MIRANDA, M. G. de; RESENDE, A. C. A. Sobre a pesquisa-ação na educação e as armadilhas do praticismo. Revista Brasileira de Educação, v. 11, n. 33, p. 511, 2006.

[124] MOORE, N. et al. Mapping the journey toward self-authorship in geography. Journal of Geography in Higher Education, v. 35, n. 3, p. 351-364, 2011.

[125] MORAES, A. C. R. Geografia: pequena história crítica. Annablume, 2003.

[126] MORAES, A. C. R. Historicidade, consciência e construção do espaço: notas para um debate. Tese de Doutorado (Doutorado em Geografia). Universidade de São Paulo, Instituto de Geografia, 1983.

[127] MORAES, L. B. de. A Cartografia na formação do professor de Geografia: contribuições da teoria do ensino Desenvolvimental. Goiânia, GO. 2014. Tese (Doutorado em Geografia). Universidade de São Paulo. 2014.

[128] MORAES, S. E. Habermas e a ação comunicativa na escola. In: MACHADO, N. J.; CUNHA, M. O. Linguagem, conhecimento, ação: ensaios de epistemologia e didática. São Paulo: Escritas Editora, 2003.

[129] MOREIRA, R. As Tendências da Geografia Universitária e da Geografia Escolar. In: para a crítica da Geografia que se ensina. São Paulo: Contexto, 2014. P. 151-160.

O discurso do avesso:

[130] MOREIRA, R. O Pensamento Geográfico Brasileiro: as matrizes clássicas originais. São Paulo: Contexto, 2008. (Volume 1).

[131] MOREIRA, R. Para Onde Vai o Pensamento Geográfico? Por uma epistemologia crítica. São Paulo: Contexto, 2008.

[132] MOREIRA, S. A. G.; ULHÔA, L. M. Ensino em Geografia: Desafios à prática docente na atualidade. Revista da Católica, Uberlândia, v. 1, n. 2, p. 69-80, 2009.

[133] MORGAN, D. The focus group guidebook. v,1. Sage publications, 1997.

[134] MORIN, A. Pesquisa-ação integral e sistêmica: uma antropopedagogia renovada. DP\&A, 2004.

[135] MORMUL, N. M.; ROCHA, M. M. Breves considerações acerca do pensamento geográfico: elementos para análise. Geografia Ensino e Pesquisa, v. 17, n. 3, set./dez., p. 64-78, 2013. 
[136] MOURA, J. D. P.; ALVES, J. Pressupostos teórico-metodológicos sobre o ensino de Geografia: elementos para a prática educativa? Geografia (Londrina), v. 11, n. 2, p. 309-320, 2010.

[137] NOBRE, M. A Teoria Crítica. Rio de Janeiro: Zahar, 2004.

[138] NOGUEIRA, R. E. A Cartografia na formação do professor de Geografia: do saber universitário ao saber a ser ensinado na escola. VI Colóquio de Cartografia para Crianças e Escolares e II Fórum Latinoamericano de Cartografia para Escolares, 2009.

[139] NOGUEIRA, R. E. A disciplina de Cartografia Escolar na universidade. Revista Brasileira de Cartografia, n. 63, Edição Especial, 2011. (ISSN 0560-4613)

[140] NOGUEIRA, R. E. Representação, comunicação e visualização cartográfica. In: I Simposio Nacional de Recursos Tecnológicos Aplicados a Cartografia e XVIII Semana da Geografia. Maringá. Maringá, 1994.

[141] OLIVEIRA NETO, A. A. de. Métodos e Técnicas. In: Metodologia da Pesquisa Científica: Guia prático para a apresentação de trabalhos acadêmicos. 2. Ed. Florianópolis, SC: Visual Books, 2006. Cap. 2.

[142] OLIVEIRA, A. L. A. M. A pesquisa-ação colaborativa e a prática docente localmente situada: dois estudos em perspectiva. Calidoscópio, v. 10, n. 1, p. 58-64, 2012.

[143] OLIVEIRA, J. M. M. de. Espaço e educação no contexto de Habermas. Humanidades \& Inovação, v. 3, n. 3, 2015.

[144] OLIVEIRA, L. Estudo metodológico e cognitivo do mapa. Tese (Livre Docência). São Paulo: IG/USP, 1978.

[145] PAGANELLI, T. Y. Para a construção do espaço geográfico na criança. Terra Livre, n. 2, p. 129-148, 1987.

[146] PASSINI, E. Y. (Org). Prática de ensino de Geografia e estágio supervisionado. Editora Contexto, 2007.

[147] PASSINI, E. Y. Os gráficos em livros didáticos de Geografia de 5a série: seu significado para alunos e professores. São Paulo: USP, 1996.

[148] PATTISON, W. D. As quatro tradições da Geografia. Boletim de Geografia Teorética, v. 7, n. 13, 1977. p. 101110

[149] PATTO, M. H. S. Teoria crítica e ciências da educação: Algumas reflexões. InterMeio: Revista do Programa de Pós-Graduação em Educação-UFMS, Campo Grande, MS. v. 14, n. 28, jul./dez. 2008. p. 167-176.

[150] PESSOA, V. L. S.; RAMIRES, J. C. de L. Amostragem em pesquisa qualitativa; subsídios para a pesquisa geográfica. In: MARAFON, G. J. et al. Geografia e Pesquisa Qualitativa: nas trilhas da investigação. Rio de Janeiro: EdUERJ, p. 117-134, 2013.

[151] PETERSON, M. P. The mental image in cartographic communication. The Cartographic Journal, v. 24, n. 1, p. 35-41, 1987.

[152] PIMENTA, S. G. Pesquisa-ação crítico-colaborativa: construindo seu significado a partir de experiências com a formação docente. Educação e pesquisa, v. 31, n. 3, 2005.

[153] PINHEIRO, A. C. O ensino de Geografia no Brasil: Catálogo de dissertação e teses (1967-2003). Goiânia: Editora Vieira, 2005.

[154] PINHEIRO, A. C. Tendências teórico-metodológicas e suas influências nas pesquisas acadêmicas sobre o ensino de Geografia no Brasil. Terra Livre, v. 1, n. 24, p. 177-191, 2005.

[155] PISSINATI, M. C.; ARCHELA, R. S. Fundamentos da alfabetização cartográfica no ensino de Geografia. Londrina. Geografia. v. 16, n. 1, jan./jun. 2007.

[156] PONTUSCHKA, N. N.; OLIVEIRA, A. U. de. Geografia em perspectiva: ensino e pesquisa. 3. ed. São Paulo: Contexto, 2009.

[157] REESE-SCHÄFER, W.; SCHNEIDER, V. Compreender Habermas. Vozes, 2012.

[158] REZENDE, A. S. Teoria Crítica: evolução e marcos teóricos. Semana Científica do Direito UFES: Graduação e Pós-graduação, v. 3, n. 3, 2016.

[159] RICHTER, D. Raciocínio geográfico e mapas mentais: a leitura espacial do cotidiano por alunos do ensino médio. Presidente Prudente, SP. 2010. Tese (Doutorado em Geografia). Universidade Estadual Paulista. Presidente Prudente. 2010.

[160] RICHTER, D.; BUENO, M. A. As potencialidades da Cartografia escolar: a contribuição dos mapas mentais e atlas escolares no ensino de Geografia. Anekumene, n. 6, p. 9-19, 2015.

[161] RICHTER, D.; MARIN, F. A.; DECANINI, M. M. Ensino de Geografia, espaço e linguagem cartográfica. MercatorRevista de Geografia da UFC, v. 9, n. 20, 2010.

[162] ROBINSON, A. H,; PETCHENIK, B. B. The Map as a Communication System. The Cartographic Journal. v. 12, n. 1, p. 7-15, 1975. 
[163] ROCHA, G. O. R. da. A trajetória da disciplina Geografia no currículo escolar brasileiro (1837 -1942). 1996. 299 f. Dissertação (Mestrado em Educação) - Pontifícia Universidade Católica de São Paulo, São Paulo, 1996.

[164] RODRIGUES, A. de J. Geografia: introdução à ciência geográfica. São Paulo: Avercamp, 2008.

[165] RODRIGUES, A. de J.; JESUS, A. S. de; SILVA, J. A. B. da. Perspectivas do ensino de Geografia com as tecnologias contemporâneas.X Encontro Internacional de Formação de Professores e Fórum Permanente de Inovação Educacional, v. 10, n. 1, 2017.

[166] SALVADORI, M. HONNETH, A. Luta por reconhecimento: a gramática moral dos conflitos sociais. CONJECTURA: filosofia e educação, v. 16, n. 1, 2011.

[167] SAMPAIO, A. C. F. et al. O ensino de Cartografia no curso de licenciatura em Geografia: uma discussão para a formação do professor. Caminhos de Geografia, Uberlândia. v. 6, n. 16, p. 14-22, outubro, 2005.

[168] SAMPAIO, M. das M. F.; MARIN, A. J. Precarização do trabalho docente e seus efeitos sobre as práticas curriculares. Educação e Sociedade, v. 25, n. 89, p. 1203-1225, 2004.

[169] SANTAELLA, L. O que é semiótica. São Paulo: Brasiliense, 2012. (Coleção primeiros passos; 103).

[170] SANTOS, B. de S. Um discurso sobre as ciências. Porto (Portugal): Afrontamento, 1999.

[171] SANTOS, C. dos. A Cartografia nos livros didáticos de Geografia: contrapontos de uma pesquisa. Ver. Ciên. Hum.. Taubaté, v. 9, n. 2, p. 107-114, 2003.

[172] SANTOS, D. A reinvenção do espaço: diálogos em torno da construção do significado de uma categoria. São Paulo: UNESP, 2002.

[173] SANTOS, F. K. S. dos. Limites e possibilidades da racionalidade pedagógica no ensino superior-a aula universitária nos cursos de licenciatura em Geografia. Revista de Geografia (Recife), v. 29, n. 1, p. 60-74, 2012.

[174] SANTOS, F. K. S. dos. Limites e possibilidades da racionalidade pedagógica no ensino superior. Educação \& Realidade, Porto Alegre, v. 38, n. 3, jul./set. 2013. p. 915-929.

[175] SANTOS, M. A construção do espaço. São Paulo: Nobel, 1986.

[176] SANTOS, R. L. Dinâmica e qualidade ambiental urbana da paisagem no município de Imperatriz (MA). Dissertação. (Mestrado em Geografia) Instituto de Estudos Socioambientais, Universidade Federal de Goiás. UFG 2017.

[177] SEEMANN, J. Subvertendo a Cartografia escolar no Brasil. Geografares, n. 12, p. 138-174, julho, 2012.

[178] SEVERINO, A. J. Metodologia do trabalho científico. 23. ed. São Paulo: Cortez, 2007.

[179] SIEBENEICHLER, F. B. Jürgen Habermas: razão comunicativa e emancipação. Rio de Janeiro: Tempo brasileiro, 1989.

[180] SILVA, M. C. A. da; GASPARIN, J. L. A Teoria da Ação Comunicativa de Jürgen Habermas e suas Influências sobre a educação escolar. Disponível http://www.histedbr.fe.unicamp.br/acer_histedbr/seminario/seminario7/TRABALHOS/M/Ma rcia\%20CA\%20Silva\%20e\%20\%20Joao\%20L\%20Gasparin1.pdf> Acesso em 14/07/2014.

[181] SILVA, P. R. F. de A. Cartografando a construção do conhecimento cartográfico no ensino de Geografia. Porto Alegre, RS. 2013. Tese (Doutorado em Geografia). Universidade Federal do Rio Grande do Sul. 2013.

[182] SILVA, S. L. P. da. Razão instrumental e razão comunicativa: um ensaio sobre duas sociologias da racionalidade. Cadernos de Pesquisa Interdisciplinar em Ciências Humanas, v. 2, n. 18, p. 2-9, 2001.

[183] SILVA, V. O da; CASSOL, R. Evolução da Cartografia no ensino da Geografia: um olhar sobre os caminhos percorridos. Geografia: Ensino \& Pesquisa, Santa Maria, RS, v. 14, n. 1, p. 85-93, 2010.

[184] SILVEIRA, D.; CORDOVA, F. A pesquisa cientifica. In: GERHARDT, T. SILVEIRA, D. (Org). Métodos da pesquisa. Porto Alegre: Editora da UFRGS. p. 31-42, 2009.

[185] SIMIELLI, M. E. R. Cartografia no ensino fundamental e médio. In: CARLOS, Ana Fani Alessandri (Org.). A Geografia na sala de aula. 5. ed. São Paulo: Contexto, 2003. p. 92-108.

[186] SIMIELLI, M. E. R. O mapa como meio de comunicação: implicações no ensino de Geografia do $1^{\circ}$ grau. São Paulo, SP. 1986. Tese (Doutorado em Geografia). Universidade de São Paulo. 1986.

[187] SOBRINHO, M. F.; GONÇALVES, E. A.; FERNANDES, P. S. R. Percurso e diversidade epistemológica da pesquisa em educação: tensionamentos e possibilidades. Cadernos de Pesquisa, v. 23, p. 81-91, 2017.

[188] SOUSA, I. B. de. A formação do professor de Geografia e as geotecnologias no ensino de Cartografia: novos desafios na educação básica. In: CONGRESSO BRASILEIRO DE CARTOGRAFIA. 2014. p. 1-11. 
[189] SOUSA, J. de M. Enredos da dinâmica urbano-regional Sulmaranhense: reflexões a partir da centralidade econômica de Açailândia, Balsas e Imperatriz. 2015. Tese de Doutorado (Doutorado em Geografia). Universidade Federal de Uberlândia. Uberlândia-MG, 2015.

[190] SOUZA, J. G. de; KATUTA, A. M. Geografia e conhecimentos cartográficos: a Cartografia no movimento de renovação da Geografia brasileira e a importância do uso dos mapas. São Paulo: Editora UNESP, 2001.

[191] SPOSITO, E. S. A propósito dos paradigmas de orientações teórico-metodológicas na Geografia contemporânea. Terra Livre. São Paulo. v. 1, n. 16. p. 99-112. set. 2001.

[192] STAKE, R. E. Pesquisa qualitativa/naturalista: problemas epistemológicos. Educação e Seleção. n. 7, jan./jun. 1983, p. 19-27.

[193] SUERTEGARAY, D. M. A. O atual e as tendências do ensino e da pesquisa em Geografia no Brasil. Revista do Departamento de Geografia, v. 16, p. 38-45, 2005.

[194] TAYLOR, D. R F. The theory and practice of cybercartography: An introduction. In: Modern Cartography Series. Academic Press, 2005. p. 1-13.

[195] TAYLOR, D. R. F; CAQUARD, S. Cybercartography: maps and mapping in the information era. Cartographica: The International Journal for Geographic Information and Geovisualization, v. 41, n. 1, p. 1-6, 2006.

[196] TAYLOR, D. R. Fifty Years of Cartography: Some Personal Reflections. Cartographic Journal, v. 50, n. 2, p. $187-$ 191,2013

[197] TARDIF, M.; GAUTHIER, C. O professor como "ator racional": que racionalidade, que saber, que julgamento? In: PERRENOUD P. (Org.). Formando professores profissionais: Quais estratégias? Quais competências? Porto Alegre: Artmed, 2001. Cap. 10.

[198] TEIXEIRA, E. T.; GRANDI, M. da S. O agir comunicativo e sua espacialidade: Reflexões a partir do exemplo da ocupação Chiquinha Gonzaga, no Centro do Rio de Janeiro. Disponível em: http://www.nuped.Geografia.ufrj.br/textos/agir-comunicativo_e_espacialidade.pdf. Acesso em: 23/06/2017.

[199] TEIXEIRA, S. K. Das imagens às linguagens do geográfico: Curitiba, a "capital ecológica". São Paulo, SP. 2001. Tese (Doutorado em Geografia). Universidade de São Paulo. 2001.

[200] THERRIEN, J. Da epistemologia da prática à gestão dos saberes no trabalho docente: convergências e tensões nas pesquisas. In: DALBEN, A., DINIZ. J., Leal, L. \& SANTOS, L.(Orgs.). Convergências e tensões no campo da formação e do trabalho docente. Belo Horizonte: Autêntica, p. 307-323, 2010.

[201] THERRIEN, J. Os saberes da racionalidade pedagógica na sociedade contemporânea. Educativa, Goiânia, v. 9, n. 1, p. 67-81, jan./jun. 2006

[202] THERRIEN, J., \& NÓBREGA-THERRIEN, S. Os trabalhos científicos e o estado da questão: reflexões teóricometodológicas. Estudos em avaliação educacional, v.15, n.30, jul.-dez. 2004.

[203] THERRIEN, J.; THERRIEN, A. A racionalidade prática dos saberes da gestão pedagógica da sala de aula. In: CANDAU, V. M. (Org.). Cultura, linguagem e subjetividade no ensinar e aprender. Rio de Janeiro: DP\&A, 2000. p. 77-95.

[204] THIOLLENT, M. J.; COLETTE, M. M. Pesquisa-ação, formação de professores e diversidade. Acta Scientiarum. Human and Social Sciences, v. 36, n. 2, 2014.

[205] THIOLLENT, M. Metodologia da pesquisa-ação. 18. Ed. São Paulo: Cortez, 2011.

[206] TRIPP, D. Pesquisa-ação: uma introdução metodológica. Educação e pesquisa, v. 31, n. 3, 2005.

[207] VEIGA, L.; GONDIM, S. M. G. A utilização de métodos qualitativos na ciência política e no marketing político. Opinião Pública, v. 7, n. 1, p. 1-15, 2001.

[208] VIEIRA, M. M. F.; CALDAS, M. P. Teoria crítica e pós-modernismo: principais alternativas à hegemonia funcionalista. Revista de Administração de Empresas, v. 46, n. 1, p. 59-70, jan./mar. 2006.

[209] WELLER, W.; PFAFF, N. Metodologias da pesquisa qualitativa em educação: teoria e prática. 3. Ed. Petrópolis, Rio de Janeiro: Vozes, 2013.

[210] WHYTE, W. F. Sociedade de esquina: a estrutura social de uma área urbana pobre e degradada. Tradução de Maria Lucia de Oliveira. Rio de Janeiro, Jorge Zahar, 2005.

[211] WOLODTSCHENKO, A. On the new generation of digital mini-atlases. AutoCarto 2012, September 16-18,

[212] WOLODTSCHENKO, A. TeleCartography: Some Cartosemiotic Aspects. In: MENG, L. Handbook of Geomathematics. Springer Berlin Heidelberg, 2010. p. 1289-1311.

[213] WOLODTSCHENKO, A.; HRUBY, F. Cybercartography in the 21st Century. meta-carto-semiotics, v. 4, n. 1, 
[214] YIN, R. K. Pesquisa qualitativa do início ao fim. Tradução: Daniel Bueno. Porto Alegre: Penso Editora, 2016.

[215] ZANTEN, A. V. Pesquisa qualitativa em educação: pertinência, validez e generalização. Perspectiva, Florianópolis, SC, v. 22, n. 1, p. 25-45, jan./jun. 2004.

[216] ZENTAI, L.; NUNEZ, J. R. (Ed.). Maps for the Future: Children, Education and Internet. Springer Science \& Business Media, 2012.

[217] ZHOU, Z. et al. Modern cartographic language. Engineering of Surveying and Mapping, v. 2, p. 001, 2008. 
Sobre os Autores 
Ronaldo dos Santos Barbosa. Professor adjunto do curso de Geografia da Universidade Estadual da Região Tocantina do Maranhão (UEMASUL). Possui graduação em Geografia pela Universidade Estadual do Maranhão (UEMA). Mestrado em Geografia pela Universidade Federal de Goiás (UFG) e Doutorado em Geografia pela Universidade Federal de Pernambuco (UFPE). É Vice-Líder do Grupo de Pesquisa: Dinâmica Ambiental, Educacional e Econômica (DAEE-UEMA) Membro do Grupo de Pesquisas Educação Geográfica, Cultura Escolar e Inovação (GPECI-UFPE). Atuando nos seguintes temas: Geografia física: Diagnóstico e gestão ambiental de bacia hidrográfica. Geotecnologias: Cartografia e Geoprocessamento. Ensino de geografia: Cartografia escolar, Formação e prática docente, Metodologias ativas aplicadas ao ensino de geografia. E-mail: ronaldobarbosa@uemasul.edu.br

Francisco Kennedy Silva dos Santos. Pós-doutorado pela Université du Québec à Montréal - Canadá. Doutor em Educação pela Universidade Federal do Ceará - UFC. Mestre e Licenciado em Geografia pela Universidade Estadual do Ceará (UECE). Coordenador do Programa de Pós-graduação em Geografia - PPGEO/UFPE. Professor permanente e pesquisador do curso de graduação em Geografia e do Programa de Pósgraduação em Geografia - PPGEO do DCG/UFPE na linha de pesquisa Educação, cultura, política e inovação na produção contemporânea do espaço. Coordenador de Área do PIBID-Geografia/UFPE. É Líder do Grupo de Pesquisa Educação Geográfica, Cultura Escolar e Inovação (GPECI/CNPQ/UFPE) e pesquisador do Grupo de Pesquisa Saber e Prática Social do Educador (da UFC/ Faculdade de Educação). Membro e Pesquisador da Rede Interregional sobre Docência na Educação Superior (RIDES). Pesquisador colaborador do Centre de Recherche Interuniversitaire sur la Formation et la Profession Enseignante (CRIFPE) da Universidade de Montréal, Canadá. Atua principalmente nos temas: Pedagogia e Docência Universitária; Formação de Professores; Inovação Pedagógica e Cultura Escolar; Didática e Metodologias do Ensino; Métodos e Técnicas de Pesquisa; Saberes Docentes e Conceituais da Ciência Geográfica; Epistemologia Científica com ênfase na Ciência Geográfica. E-mail: kennedyufpe@gmail.com 
Agência Brasileira do ISBN ISBN 978-85-7042-153-1

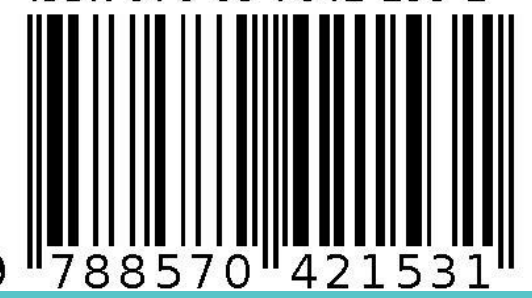

